SRNS-STI-2011-00024

Revision 0

KEY WORDS:

PA

CA

ELLWF

Retention: Permanent

FY2010 ANNUAL REVIEW

\title{
E-AREA LOW-LEVEL WASTE FACILITY PERFORMANCE ASSESSMENT AND COMPOSITE ANALYSIS
}

\author{
R. F. Swingle, II \\ B. T. Butcher \\ K. P. Crapse \\ M. R. Millings \\ D. F. Sink
}

January 2011

Savannah River National Laboratory

Savannah River Site

Aiken, SC 29808

Prepared for the U.S. Department of Energy Under Contract Number DEAC09-08-SR22470

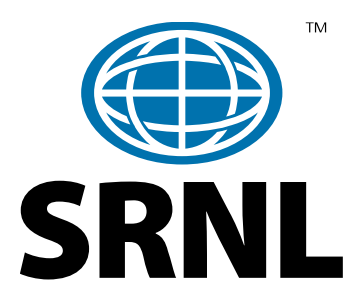




\section{DISCLAIMER}

This work was prepared under an agreement with and funded by the U.S. Government. Neither the U. S. Government or its employees, nor any of its contractors, subcontractors or their employees, makes any express or implied: 1. warranty or assumes any legal liability for the accuracy, completeness, or for the use or results of such use of any information, product, or process disclosed; or 2. representation that such use or results of such use would not infringe privately owned rights; or

3. endorsement or recommendation of any specifically identified commercial product, process, or service.

Any views and opinions of authors expressed in this work do not necessarily state or reflect those of the United States Government, or its contractors, or subcontractors.

Printed in the United States of America

Prepared For

U.S. Department of Energy 


\title{
TABLE OF CONTENTS
}

\author{
1.0 PERFORMANCE ASSESSMENT ANNUAL SUMMARY ................................ 1

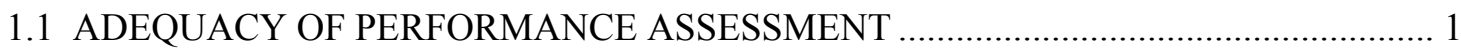

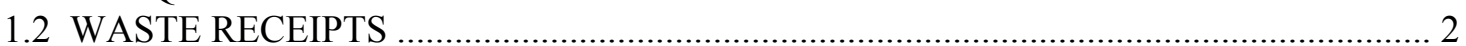

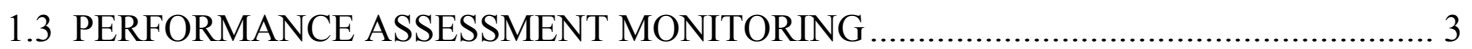 \\ 1.4 PERFORMANCE ASSESSMENT RESEARCH AND DEVELOPMENT $\ldots \ldots \ldots \ldots \ldots \ldots \ldots . . . \ldots \ldots$

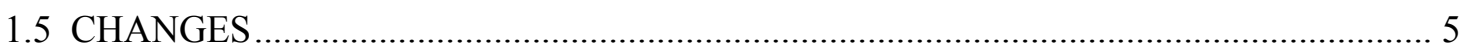

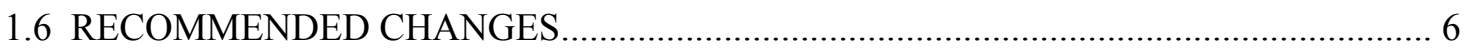

2.0 COMPOSITE ANALYSIS ANNUAL SUMMARY ..................................... 7

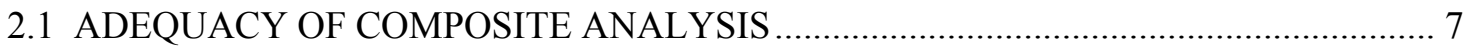

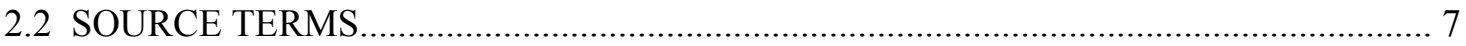

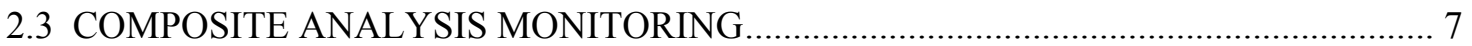

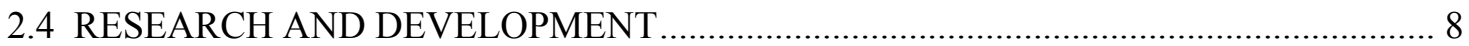

2.5 CHANGES

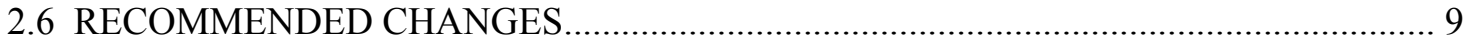

3.0 PERFORMANCE ASSESSMENT ANNUAL DETERMINATION ................. 10

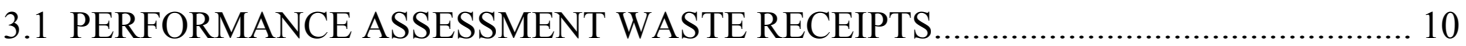

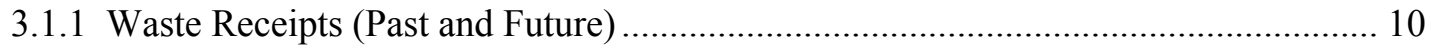

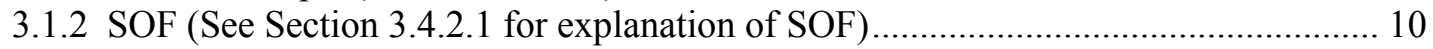

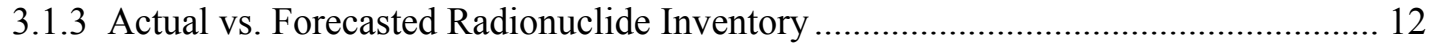

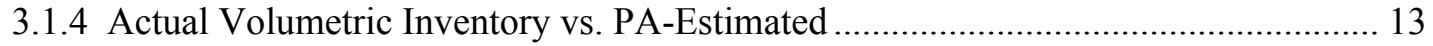

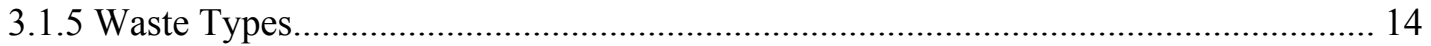

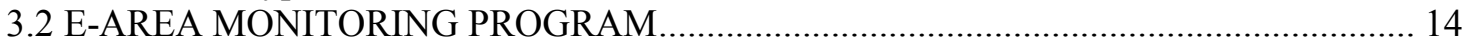

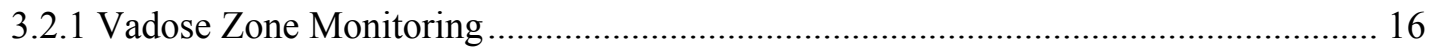

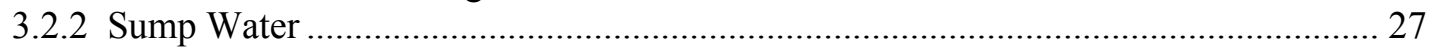

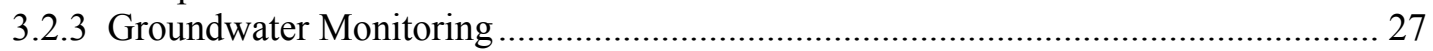

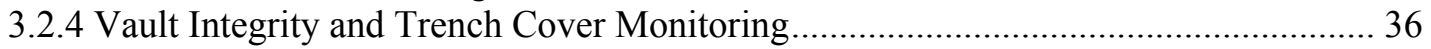

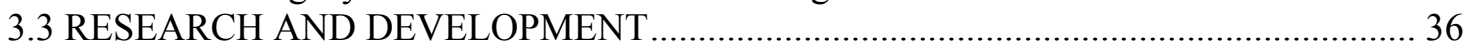

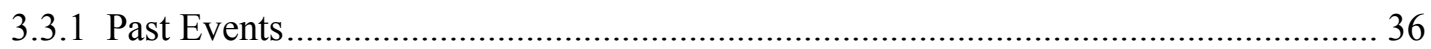

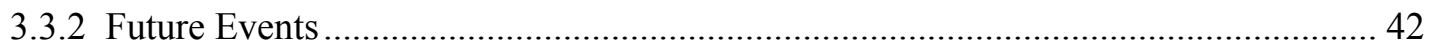

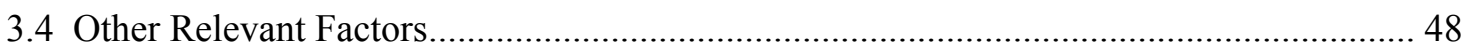

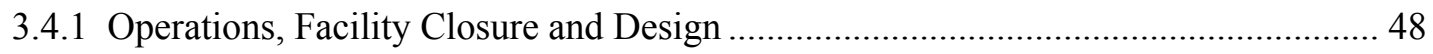

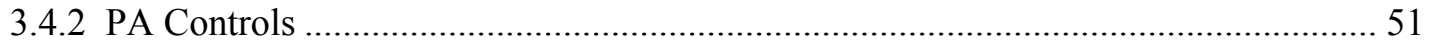

4.0 COMPOSITE ANALYSIS ANNUAL DETERMINATION............................... 57

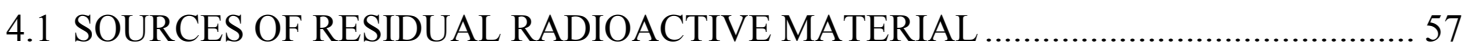

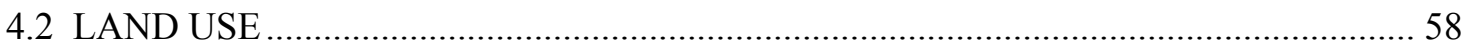

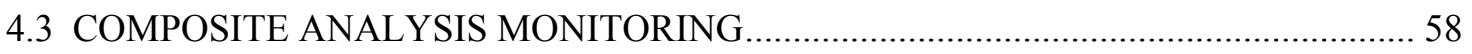

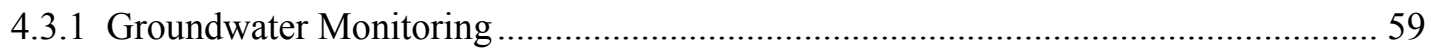

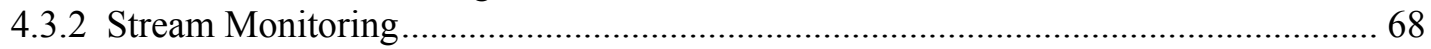

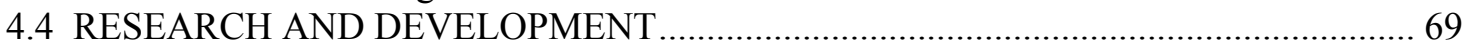

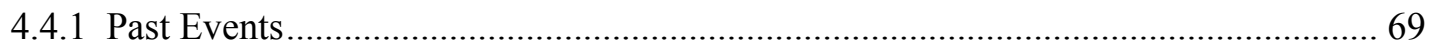

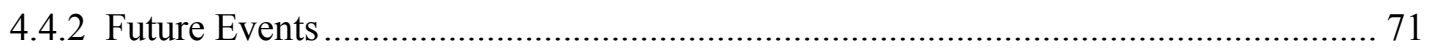

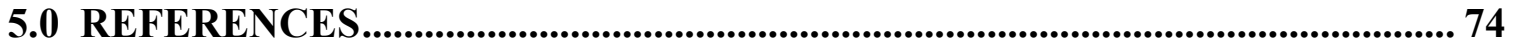




\section{LIST OF FIGURES}

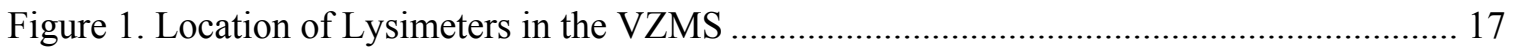

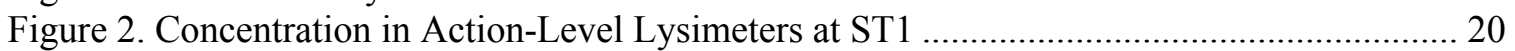

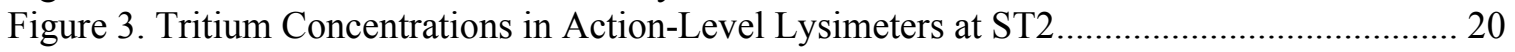

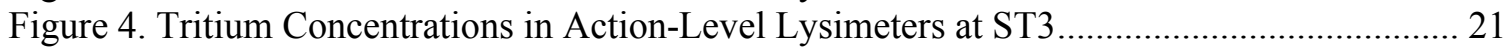

Figure 5. Tritium Concentrations in Action-Level Lysimeters at ST5 ................................... 21

Figure 6. Tritium Concentrations in Action-Level Lysimeters at STs 4, 6 \& 7 ........................ 22

Figure 7. Tritium Concentrations in Action-Level Lysimeters at ST 8 …................................ 22

Figure 8. Tritium Concentrations in Action-Level Lysimeters at ET1 ..................................... 23

Figure 9. Tritium Concentrations in Action-Level Lysimeters at ET2 ...................................... 23

Figure 10. Tritium Concentrations in Action-Level Lysimeters at CIG Trench .......................... 24

Figure 11. Map of the BGO and BGX Water Table Wells in E-Area Vicinity............................ 29

Figure 12. Groundwater Divide and Shallow Groundwater Flow Directions in E-Area Vicinity 30

Figure 13. E-Area Vicinity Tritium Plumes Moving to North and South Sides of Groundwater

Divide in UAZ

Figure 14. E-Area Vicinity Tritium Plumes Moving to North and South Sides of Groundwater

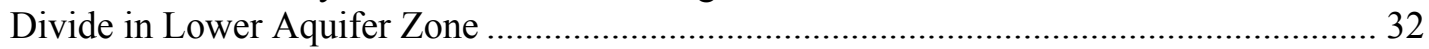

Figure 15. Tritium Plumes Moving from MWMF to ELLWF in UAZ ...................................... 33

Figure 16. Tritium Plumes Moving from MWMF to ELLWF in Lower Aquifer Zone................. 34

Figure 17 Background nitrate locations are shown overlaid on a historical aerial photograph

depicting the extent of farming (lighter areas) prior to establishment of the SRS................65

Figure 18. Showing HAA and HTF well locations and HTF tank locations (Tanks 9-12 are Type

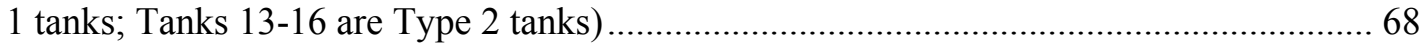

\section{LIST OF TABLES}

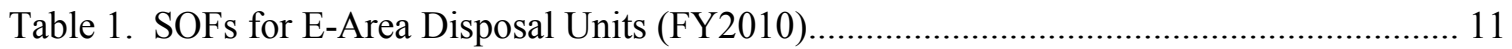

Table 2. FY2010 PA - Estimated Radionuclide Inventory vs. Actual \& Forecast Inventory ...... 12

Table 3. FY2010 Status of ELLWF Disposal Unit Capacity ..................................................... 13

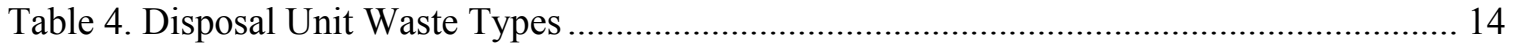

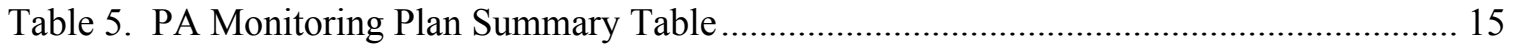

Table 6. Summary of PA Monitoring Results for FY2009 …................................................. 16

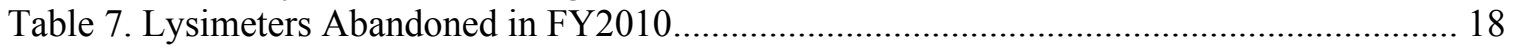

Table 8. Action Level Lysimeters with Tritium Concentrations $>10 \mathrm{pCi} / \mathrm{mL}$ in FY2010 …....... 26

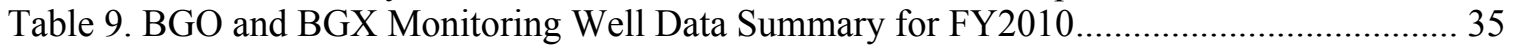

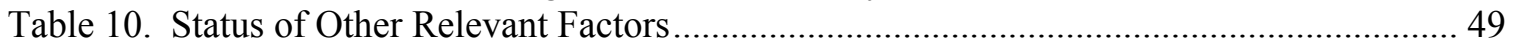

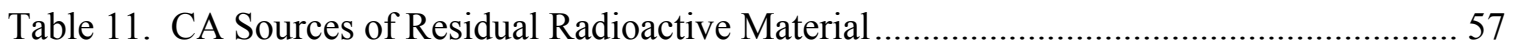

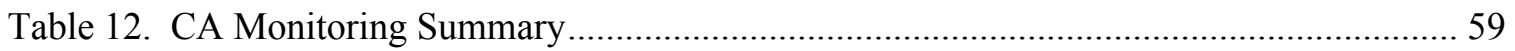

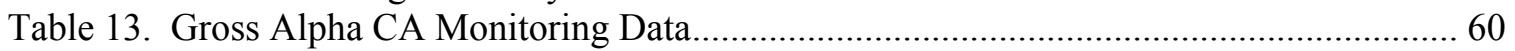

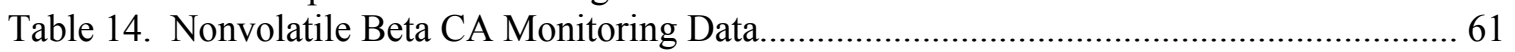

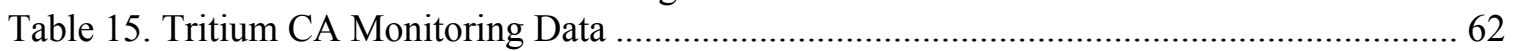

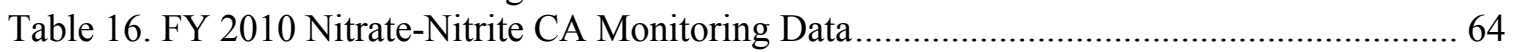

Table 17 Average nitrate monitoring data for each background monitoring location (January

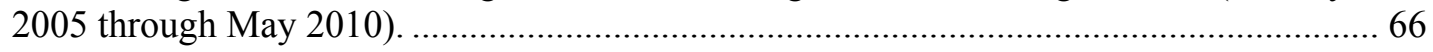

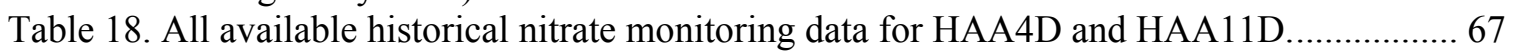

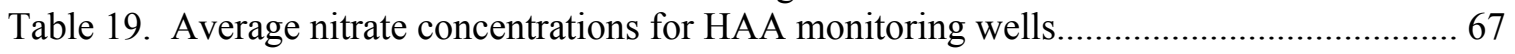




\section{LIST OF ACRONYMS/ABBREVIATIONS}

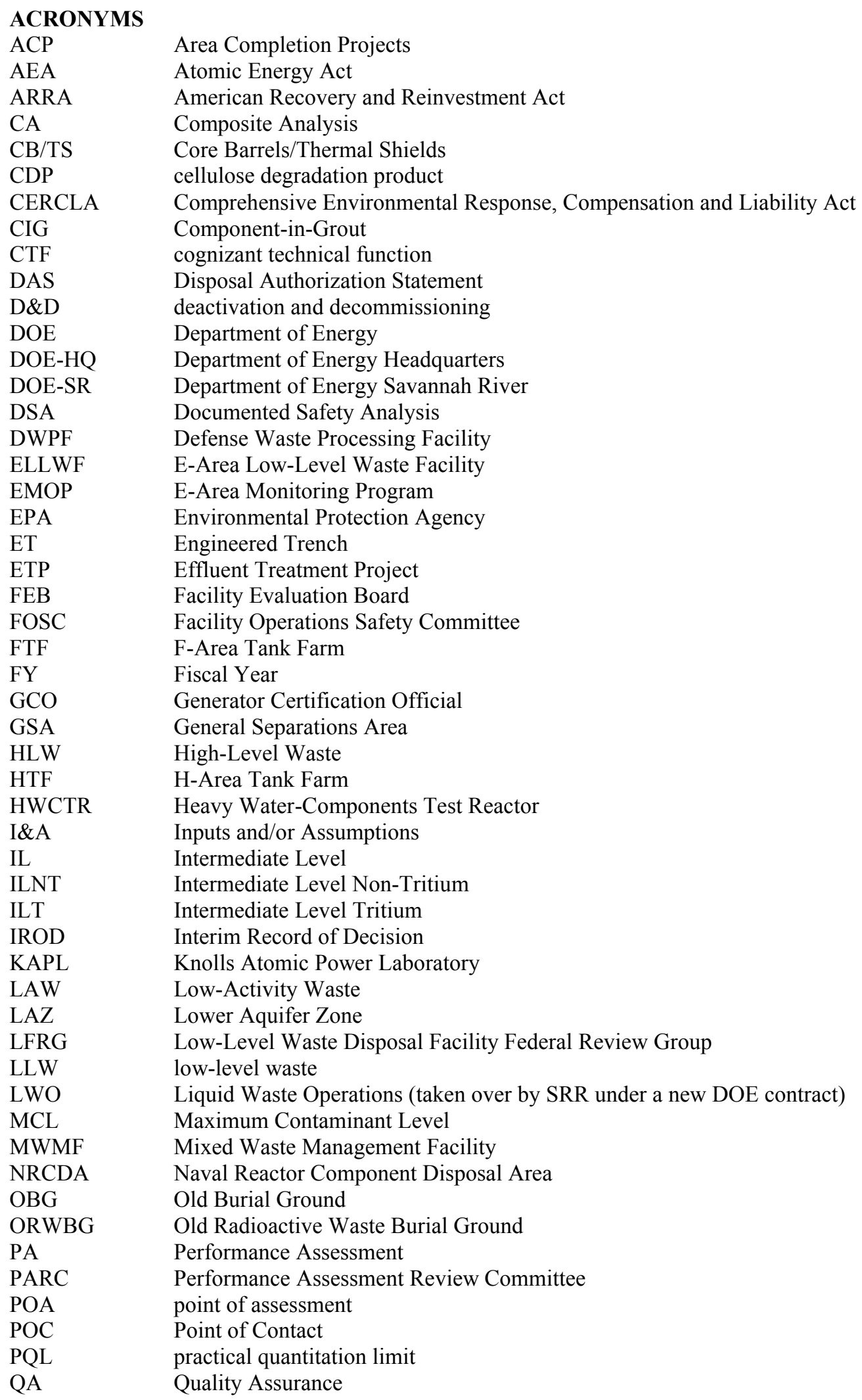




$\begin{array}{ll}\text { QAP } & \text { Quality Assurance Procedure } \\ \text { R\&D } & \text { research and development } \\ \text { RCRA } & \text { Resource Conservation and Recovery Act } \\ \text { RI\&ES } & \text { Regulatory Integration and Environmental Services } \\ \text { RWMB } & \text { Radioactive Waste Management Basis } \\ \text { SA } & \text { Special Analysis } \\ \text { SCDHEC } & \text { South Carolina Department of Health and Environmental Control } \\ \text { SDD } & \text { Site Deactivation and Decommissioning } \\ \text { SDF } & \text { Saltstone Disposal Facility } \\ \text { SIRIM } & \text { Site Item Reportability and Issue Management } \\ \text { SMP } & \text { Site Monitoring Program } \\ \text { SOF } & \text { sums-of-fractions } \\ \text { SREL } & \text { Savannah River Ecology Laboratory } \\ \text { SRNL } & \text { Savannah River National Laboratory } \\ \text { SRNS } & \text { Savannah River Nuclear Solutions } \\ \text { SRR } & \text { Savannah River Remediation } \\ \text { SRS } & \text { Savannah River Site } \\ \text { ST } & \text { Slit Trench } \\ \text { SWM } & \text { Solid Waste Management } \\ \text { SWMF } & \text { Solid Waste Management Facility } \\ \text { TCCZ } & \text { Tan Clay Confining Zone } \\ \text { TRU } & \text { transuranic } \\ \text { TSD } & \text { Treatment, Storage and Disposal } \\ \text { UAZ } & \text { Upper Aquifer Zone } \\ \text { UDQ } & \text { Unreviewed Disposal Question } \\ \text { UDQE } & \text { Unreviewed Disposal Question Evaluation } \\ \text { USQ } & \text { Unreviewed Safety Question } \\ \text { VZMS } & \text { Vadose Zone Monitoring System } \\ \text { WAC } & \text { Waste Acceptance Criteria } \\ \text { WITS } & \text { Waste Information Tracking System } \\ \text { WSCF } & \text { Waste Stream Characterization Form } \\ \text { WSRC } & \end{array}$




$\begin{array}{ll}\text { ABBREVIATIONS } \\ \mathrm{bls} & \text { below land surface } \\ \mathrm{Ci} & \text { curie } \\ \mathrm{dpm} & \text { disintegrations per minute } \\ \mathrm{ft} & \text { foot } \\ \mathrm{g} & \text { gram } \\ \mathrm{k} & \text { kilo } \\ \mathrm{K}_{\mathrm{d}} & \text { sorption coefficient } \\ \mathrm{km} & \text { kilometer } \\ \mathrm{L} & \text { liter } \\ \mathrm{m} & \text { meter } \\ \mu \mathrm{g} & \text { microgram } \\ \mathrm{mg} & \text { milligram } \\ \mathrm{mL} & \text { milliliter } \\ \mathrm{mrem} & \text { millirem } \\ \mathrm{msl} & \text { mean sea level } \\ \mathrm{pCi} & \text { picocurie } \\ \mathrm{ppm} & \text { parts per million } \\ \mathrm{yr} & \text { year }\end{array}$




\subsection{PERFORMANCE ASSESSMENT ANNUAL SUMMARY}

The E-Area Low-Level Waste Facility (ELLWF) consists of a number of disposal units described in the Performance Assessment (PA)(WSRC, 2008b) and Composite Analysis (CA)(WSRC, 1997; WSRC, 1999): Low-Activity Waste (LAW) Vault, Intermediate Level (IL) Vault, Trenches (Slit Trenches [STs], Engineered Trenches [ETs], and Component-in-Grout [CIG] Trenches), and Naval Reactor Component Disposal Areas (NRCDAs). This annual review evaluates the adequacy of the approved 2008 ELLWF PA along with the Special Analyses (SAs) approved since the PA was issued. The review also verifies that the Fiscal Year (FY) 2010 low-level waste (LLW) disposal operations were conducted within the bounds of the PA/SA baseline, the Savannah River Site (SRS) CA, and the Department of Energy (DOE) Disposal Authorization Statement (DAS). Important factors considered in this review include waste receipts, results from monitoring and research and development (R\&D) programs, and the adequacy of controls derived from the PA/SA baseline. Sections 1.0 and 2.0 of this review are a summary of the adequacy of the PA/SA and CA, respectively. An evaluation of the FY2010 waste receipts and the resultant impact on the ELLWF is summarized in Section 3.1. The results of the monitoring program, R\&D program, and other relevant factors are found in Section 3.2, 3.3 and 3.4, respectively. Section 4.0 contains the CA annual determination similarly organized.

SRS low-level waste management is regulated under DOE Order 435.1 (DOE, 1999a) and is authorized under a DAS as a federal permit. The original DAS was issued by the DOE-Headquarters (DOE-HQ) on September 28, 1999 (DOE, 1999b) for the operation of the ELLWF and the Saltstone Disposal Facility (SDF). The 1999 DAS remains in effect for the regulation of the SDF. Those portions of that DAS applicable to the ELLWF were superseded by revision 1 of the DAS on July 15, 2008 (DOE, 2008b). The 2008 PA and DAS were officially implemented by the facility on October 31, 2008 and are the authorization documents for this FY2010 Annual Review.

Department of Energy Headquarters approval of the 2008 DAS was subject to numerous conditions specified in the document. Two of those conditions are to update the ELLWF closure plan and monitoring plan to align with the conceptual model analyzed in the PA. Both of these conditions were met with the issuance of the PA Monitoring Plan (Millings, 2009a) and the Closure Plan (Phifer et al, 2009a). The PA Monitoring Plan was approved by DOE on July 22, 2009 and the Closure Plan was approved by DOE on May 21, 2009. Both will be updated as needed to remain consistent with the PA. The DAS also specifies that the maintenance plan include activities to resolve each of the secondary issues identified in the DOEHQ review of the 2008 PA that were not completely addressed either with supplemental material provided to the review team or in final revisions to the PA. These outstanding issues were originally documented in the 2008 update of the PA/CA Maintenance Plan (WSRC, 2008a) and in subsequent PA/CA Maintenance Plans (most recently SRNS, 2010a) as required and are actively being worked.

\subsection{ADEQUACY OF PERFORMANCE ASSESSMENT}

This PA Annual Review has shown that LLW operations conducted in FY2010 were well within the performance envelope analyzed in the PA/SA and the CA. Operations were conducted in accordance with the requirements of the 2008 ELLWF DAS (DOE, 2008b). The PA/SA controls including the SAs, Unreviewed Disposal Question Evaluations (UDQEs) and PA/CA Maintenance Plan have been designed with an internal check and balance system to verify that the controls are adequate to ensure compliance. These built-in mechanisms have demonstrated the program's ability to identify potential problems that can then be averted to ensure the program remains within the PA/SA limits. The adequacy of the PA/SA controls is summarized in the following statements:

- The SA and UDQE Programs continue to evaluate proposed actions, changes and new information to determine if these activities are within the boundaries analyzed in the approved PA. The program completed one SA and one UDQE in FY2010. The details of these activities can be seen in the R\&D section of this summary and the annual determination. 
- Periodic assessments of waste generators' waste certification programs are included in the scope of the SRS Facility Evaluation Board (FEB) assessments. FEB assessments were performed on nine waste generators during FY2010. Corrective actions have been implemented for waste certification program deficiencies identified during these assessments.

- Periodic reviews and assessments performed by DOE-SR.

- Any non-conformance identified during waste receipts will establish corrective actions to prevent recurrences.

- Receipt inspections of waste at the Solid Waste Facilities are conducted to ensure compliance with the Waste Acceptance Criteria (WAC) in the SRS 1S Manual, Waste Acceptance Criteria (SRS, 2009). This is accomplished through the use of a comprehensive database called Waste Information Tracking System (WITS) that checks against PA and Documented Safety Analysis (DSA) requirements.

- In accordance with DOE Order 435.1, the ELLWF is designed, operated and maintained in a manner that is protective of human health and the environment (DOE, 1999a). As part of the regulatory agreement for receipt of Comprehensive Environmental Response, Compensation and Liability Act (CERCLA) LLW, DOE agreed to the placement of operational storm water runoff covers over ELLWF ST Disposal Units that have reached design capacity (i.e., curie and/or volume capacity limits) as an enhancement to the current protective measures and to document this action in an Interim Record of Decision (IROD). In addition, the agreement increases regulatory participation in the final closure decisions for the entire ELLWF. In all other respects, the DOE will continue to operate the ELLWF in accordance with DOE requirements under its Atomic Energy Act (AEA) authority. Consequently, the ST Disposal Units have been determined to be acceptable for the receipt of CERCLA LLW (EPA, 2008).

- Integrated management evaluation (trending) is conducted to gauge the waste certification program site-wide. In order to qualify the data from these evaluations, a comparative risk analysis is performed and assigned a rating of "Excellent," "Good" or "Poor." FY2010 continued the positive waste certification program trend by maintaining an overall "Good" performance rating.

- Key PA and SA inputs and assumptions, when applicable, are protected in operational procedures.

\subsection{WASTE RECEIPTS}

- The radionuclide inventory limits calculated in the PA/SA are implemented in the WAC. The limits are tracked as fractions of the individual radionuclide limits in WITS. The sum of these fractions for each disposal unit is controlled to less than or equal to one to ensure compliance with each PA performance measure's limits. SWM typically operates most low-level waste facilities with a 0.95 sum-of-fraction administrative limit.

- The sums-of-fractions (SOF) for both disposed and forecasted radionuclide inventories for all disposal units are less than one.

- Because of SRS waste minimization and volume reduction programs, a total of one LAW Vault and one IL Vault are estimated to be needed for low-level radioactive waste disposal over the next 25 years. The Solid Waste System Plan (WSRC, 2006) used a systems engineering approach to evaluate appropriate disposal paths for LLW. Through this evaluation, it was determined that LLW, which met the trench (i.e., ST and ET) WAC (SRS, 2009), was being disposed in the LAW Vault. In FY2010, Solid Waste continued a campaign in the LAW Vault to move lower activity waste from the vault into the STs (i.e., mining), freeing up valuable vault space for later use. In FY2010, the total disposed volume in the LAWV decreased by $9 \%$ from FY2009 based on the large mining effort and the low disposal waste volumes received in FY2010 $\left(196 \mathrm{~m}^{3}\right)$ to the LAW Vault. The mined containers to the 
ST had low curie contents while the new LAW Vault waste receipts in FY2010 were primarily tritium waste packages which increased the total curie content in the LAW Vault by $25.5 \%$ since FY2009. Therefore, the LAW Vault is not expected to be filled for 25 years. After sixteen years of IL Vault operation, approximately $51 \%$ of the available volume in the nine cells has been filled with waste that contains $38 \%$ of the allowable radionuclide inventory. The IL Vault is also projected to be filled in about 25 years.

- Seven B-25 waste containers were inadvertently disposed in a ST in the Solid Waste Management Facility (SWMF). Disposal of these containers caused the radiological inventory in the specific ST to exceed the PA disposal limits. Five of the waste containers were located in an area that had not yet been covered with soil and four of these five containers were retrieved. The fifth container was determined to be within waste acceptance criteria and was not retrieved. The remaining two waste containers were determined to be buried in closed trench segment. SWM evaluated the effort to retrieve these final two waste packages and determined that the work would be much more hazardous to personnel and operationally challenging than the retrieval of the first four waste containers. SWM commissioned SRNL to perform a Special Analysis with a more accurate accounting of actual disposal locations and operational closure conditions in this set of slit trenches to determine if these two waste containers were within the bounds of the Performance Assessment. The Special Analysis concluded that the radionuclide inventory from these two waste containers was well within the allowable limits of the PA and therefore could be left disposed in place. See Section 3.3.1.1 and 3.4.2.5 for more details.

\subsection{PERFORMANCE ASSESSMENT MONITORING}

The E-Area Monitoring Program (EMOP) monitors the vadose zone, sump water, groundwater and vault integrity at the ELLWF. In FY2010, modifications were made to the lysimeter network at STs 1, 2, 3, 4, and 5 in preparation for construction of the stormwater runoff covers. These modifications included lysimeter cluster abandonments and the raising or lowering of remaining sampling pads. These modifications were required in order to avoid interfering with the stormwater runoff covers.

Analytical results from the FY2010 sampling of the sumps, vadose zone lysimeters and groundwater were below established action levels except for two lysimeters (VL-26-West and ST7-VL-2). A value above the calculated action level does not indicate that groundwater concentrations will rise above the drinking water standard at the compliance point. In fact, the E-Area Monitoring Program is designed to allow opportunities for investigation of performance trends well before groundwater radionuclide concentrations approach regulatory limits in order to gain more information as monitoring occurs and, if needed, to develop preemptive plans. Action levels would have to be simultaneously exceeded by a factor of 4 over a significant portion of the trench in a number of the deepest lysimeters (closest to the aquifer) before there is a danger of exceeding groundwater drinking standards.

A hierarchical approach is taken to investigate data above the action level. For VL-26-West, previous actions have included review of existing data (e.g., tritium data, geology, and disposal history), additional sampling, and one-dimensional modeling using existing data. In FY2010, a field characterization study was conducted at VL-26-West. Characterization included: 1) drilling vertical boreholes adjacent to the VL26 lysimeter cluster; 2) drilling angled boreholes beneath the adjacent waste trench; 3) soil sampling for analysis of tritium, cobalt-60 and iodine-129 in porewater; 4) collection of Shelby tube samples for analysis of soil physical properties and 5) collection of groundwater for tritium, cobalt-60 and iodine-129 analyses. Soil and water analyses from this study indicate that the tritium emanating from ST 1 near VL-26 is fairly localized and has had no discernable effect on groundwater near the ST. Tritium activities in groundwater samples were within the documented range for an existing plume that emanates from the adjacent mixed waste facility. Cobalt- 60 and iodine-129 were not detected in groundwater or soil samples analyzed as part of this effort.

ST7-VL-2 is a relatively new lysimeter cluster with little data. Since its installation, tritium concentrations in this action level lysimeter have hovered near the action level. No elevated tritium has been observed in 
the shallow lysimeters at this cluster or in any of the lysimeters at the adjacent clusters. As with VL-26West, a hierarchical approach will be taken to investigate these data. This approach will likely include reviewing data from adjacent lysimeter clusters along with assessing existing knowledge about the geology and disposal history for the specific areas.

Inspection of vault walls, roof and floor in February 2009 showed no significant cracking or degradation beyond what is assumed for the PA.

\subsection{PERFORMANCE ASSESSMENT RESEARCH AND DEVELOPMENT}

One Unreviewed Disposal Question Evaluation was completed by SRNL and approved by Solid Waste Management (SWM) in FY2010. SRNL prepared a report describing the evaluation of a proposed activity by SWM to install additional concrete anchors in the floor of the E-Area LAW Vault Cell 11 to support an extension of the temporary airlock enclosure to be used for waste repackaging operations. Floor anchors will be removed when the airlock facility is decommissioned. Holes in the floor will be sealed with a material and method that will produce the same hydraulic characteristics as the original vault concrete.

One Special Analysis was completed by SRNL and approved by SWM and DOE in FY2010. SRNL completed a SA to support approval for returning one of the STs back into operation. Operations at the Fourth Set of Slit Trenches (SLIT4) had been halted due to inadvertent disposal of waste that did not meet the WAC for tritium. SWM discovered seven packages of low-level waste were mistakenly placed into SLIT4 because of incorrect container labeling. Four of the packages were retrieved from an open trench segment, one package was determined to meet the Slit Trench WAC and left in place, and the final two packages were in a trench segment that had subsequently been covered with soil. Modeling conclusively demonstrated the tritium inventories in the two covered waste packages are well within new tritium groundwater limits established in this SA and could be left in the trench.

Eighteen Preliminary Studies were completed in FY2010. One of these studies provided an update on the status of the SRS bamboo nursery study. Three preliminary studies dealt with site geochemistry: one examined neptunium sorption in the SRS environment, one examined iodine geochemistry in the site environment and the third updated the Geochemical Data Package used as input for PA and CA studies. Preliminary studies are typically used to fill data gaps in the PA, confirm current PA assumptions or support ongoing SAs by defining wasteform or disposal specific conditions. They can also be used to develop new approaches to PA analysis or to evaluate alternatives to the current baseline.

Two studies examined the durability and time-to-failure of stainless steel vessels containing Effluent Treatment Project (ETP) carbon bed material. Four studies examined the feasibility of disposing of components of Heavy Water Components Test Reactor (HWCTR) in the ELLWF. These studies included one which examined the overall feasibility of disposal of HWCTR in E Area. Two determined the radionuclide inventories associated with the components and the final study examined the structural stability of the HWCTR components. These studies are being used to support an ongoing SA evaluating Slit Trench disposal of HWCTR.

Two reports that discuss infiltration projections and a revised waste zone representation have been produced to support future Slit Trench special analyses. The first report provides Slit Trench closure cap infiltration estimates for both intact and subsided conditions for two different trench spacings. The second document provides a hybrid Slit Trench waste representation that combines bulk waste and containerized waste representations in a manner that conserves mass so that radionuclide retardation is not unduly conservative or non-conservative. Results from these studies will be used to support future Slit Trench SAs.

Three studies dealt with performance of engineered barriers. A literature search was conducted on factors affecting long term hydraulic performance of the final closure cap drainage layer which will serve as the basis for designing future lab and field studies. In another report, Clemson University conducted a proof-ofconcept study of an analytical method of modeling flow and transport through a fractured cementitious 
SRNS-STI-2011-00024, Revision 0

matrix using various patterns of fractures, and proposed a method for developing an effective $\mathrm{Kd}$ as a function of fracture density. SRNL prepared a third report documenting the results of simulations performed by SIMCO Technologies, Inc. on the degradation of E-Area concrete vaults and grout barriers with long term exposure to SRS subsurface conditions. These studies are designed to fill data gaps in our current PA models.

Three reports documented performance of and changes in E-Area lysimeters. One report is a characterization plan for conducting a field investigation of tritium levels at the VL-26 lysimeter. The second report documents the results and conclusions of this field study. The third report documents the modification and removal of selected lysimeters to accommodate the new operational rainwater covers over STs 1-5.These studies provide for interpretation of vadose zone monitoring data and justify changes to the vadose zone monitoring system.

Twelve PA Maintenance activities were completed in FY2010, including three annual maintenance activities. The first was the annual update of the PA-CA maintenance plan that lays out the overall program scope, schedule and budget through a moving ten-year window. The second annual maintenance activity was the FY2009 PA and CA annual review that evaluates the previous year's LLW facility operations relative to the PA and CA baseline and describes past and future PA and CA work. The final annual maintenance activity involved updating the ELLWF Limits Database to include new limits produced in the one SA completed during FY2010.

Three workshops were held to maintain and upgrade modeler proficiency. One consisted of training on the PORFLOW code for new and existing users. A second workshop gave training on the GoldSim code for new and existing users. The final workshop consisted of training and discussions on handling of sensitivity and uncertainty issues in PA modeling. Three activities involved verification and acceptance of new versions of the PORFLOW and GoldSim codes which are being employed in the latest SA's and uncertainty analyses. GoldSim modeling improvements were jointly developed by SRNL and Neptune and Co. including an overall GoldSim model for STs, ETs and CIG trenches, and a GoldSim database containing geochemical parameter distributions to be used in probabilistic modeling. Finally, several improvements were made to the way in which the PORFLOW code is run that greatly improved efficiency.

\subsection{CHANGES}

The following changes have been or are being made to disposal operations as a result of recent PA activities. A summary discussion of these changes can be found in sections 3.3.1.1, 3.3.1.2, 3.4.1 and 3.4.2.5.

- Implementation of increased tritium limits to allow SLIT4 to be reopened for operation after two high tritium inventory containers were discovered to be buried in this trench.

- Installation of additional concrete anchors in the floor of the LAW Vault Cell 11 to support a facility's modification within the cell for processing waste on an interim basis.

- Closure of Engineered Trench 1 sump and construction of a new sump in Engineered Trench 2.

- Filling and operational closure of SLIT3 and SLIT4.

- Installation of operational storm water runoff covers over the first five sets of STs.

- Modification and demolition of selected vadose zone lysimeters to accommodate installation of stormwater covers over the first set of five slit trenches. 


\subsection{RECOMMENDED CHANGES}

A number of activities are underway or are planned which either may provide more operational flexibility for Solid Waste or increase confidence in PA results:

- Complete the revised analysis of operational storm water runoff covers over filled E-Area STs one through five using the actual cover emplacement timing.

- Complete the analysis for Slit Trench disposal of the Heavy Water Components Test Reactor vessel.

- $\quad$ Perform an evaluation for disposal of future 'tall' used storage equipment boxes with heights exceeding the standard 20-foot thick waste zone in Slit Trenches 8,9 and 10.

- $\quad$ Continue field and laboratory investigations to improve I\&A to the models (e.g., geochemical and material properties, interim cover durability, and any emerging items). Revise baseline data reports annually as necessary.

- Perform SAs to ensure that the lowest cost disposal options are selected consistent with DOE performance objectives. These analyses will include currently recognized issues as well as emergent items.

- Continue efforts to improve control of the technical baseline for disposal operations (e.g., UDQEs, baseline model reports, maintain Radioactive Waste Management Basis (RWMB) limits database, validation of PA with E-Area monitoring results, revision to the ELLWF Closure Plan and CA Monitoring Plan, and update the PA Maintenance Plan).

- Screen available groundwater modeling codes for potential use. Maintain and upgrade other computer codes and models as needed.

- Continue to resolve uncertainties with respect to the conceptual and numerical model representation of disposal units (e.g., refine the use of probabilistic methods in performing uncertainty analyses using GoldSim). 


\subsection{COMPOSITE ANALYSIS ANNUAL SUMMARY}

The original SRS CA (WSRC, 1997; WSRC, 1999) included both of the active LLW disposal facilities, the ELLWF and the SDF. The CA also included all sources of radioactive material in the central part of the SRS, which is called the General Separations Area (GSA). Thus, both of the chemical separations facilities, all of the high-level waste storage tanks, the Defense Waste Processing Facility (DWPF), and numerous other potential sources were considered. In total, the analysis included 114 potential sources of radioactive material and 115 radionuclides. Of these, only a few radionuclides (i.e., H-3, C-14, Np-237, and isotopes of uranium because of their inventories, transport properties and dose effects) and two sources (i.e., the Mixed Waste Management Facility [MWMF] and the Old Burial Ground [OBG] because of the size of the inventory and minimal containment) are significant.

In July 2010 DOE-HQ approved a new SRS Composite Analysis (SRNS, 2010c). Since the site operated under the original 1997 CA (WSRC, 1997) for most of FY10 this annual review is being performed against the original CA. Compliance with the $2010 \mathrm{CA}$ will be evaluated for the first time in next year's annual review.

This review evaluates the adequacy of the 1997 CA and verifies that SRS activities were conducted within the bounds of the analysis. Important factors considered in this review include source terms, monitoring and R\&D activities. Section 2.1 of this summary includes discussion on the adequacy of the CA. An evaluation of source terms is discussed in Section 2.2. Monitoring, as applied to the CA, is discussed in Section 2.3. In Section 2.4 R\&D activities in the context of the CA are discussed. In Section 2.5 changes that have taken place are discussed while Section 2.6 contains recommended changes in the CA.

\subsection{ADEQUACY OF COMPOSITE ANALYSIS}

This CA annual review has shown that SRS LLW disposal activities, as well as other activities, conducted in FY2010 did not adversely impact the CA. The ELLWF PA annual review (contained herein) and SDF PA annual review (SRR, 2010a) have shown that operations at the site's two LLW disposal facilities were within the bounds of the PA, thus, there was no impact on the CA. The CA review has shown that no significant changes in source terms or land use controls have occurred. None of the R\&D activities have resulted in any negative impact on the validity of the results of the current CA.

\subsection{SOURCE TERMS}

The CA annual review has concluded that there have been no significant changes in any of the source terms analyzed in the CA that would alter the analysis or conclusions of the CA. Specifically, operations at the ELLWF and SDF have been conducted within the bounds of currently approved radionuclide limits. In addition, no new major facility closures have occurred within the GSA since the last Annual Review that would replace original CA inventory estimates of final residual inventories.

\subsection{COMPOSITE ANALYSIS MONITORING}

The 1997 CA determined that the only significant migration pathway is groundwater that discharges to surface water streams. The only potential exposure pathway for the public is through exposure to surface water. Therefore, monitoring of groundwater was performed in close proximity to the facilities identified in the CA as primary contributors of contaminant flux to the groundwater (i.e., the ORWBG, MWMF, and the HTF). Monitoring of the surface water in Upper Three Runs and Fourmile Branch was performed to 
evaluate the projections in the $1997 \mathrm{CA}$ for the composite effects of all facilities considered. A discussion of how action levels were set can be found in section 4.3.

The CA monitoring plan was revised in FY2009 (Crapse, 2009) to make minor adjustments corresponding with changes in the current site monitoring program. This annual assessment of CA monitoring results for FY2010 reflects these revisions. The site program has evolved over the last several years resulting in some new monitoring locations, sampling frequencies and sample analytes at a number of facilities including changes at the ORWBG, MWMF and HTF. New wells and changes in analytes were selected in the monitoring plan revision to be consistent with those wells and analytes that are currently being sampled under the site monitoring program while still meeting the monitoring needs of the CA. In the HTF, nitrate was selected as an early indicator of contaminant migration. Nitrate monitoring locations at HTF were added in the revised Plan and the action level for nitrate was set to be $25 \%$ of the MCL (i.e., $2.5 \mathrm{ppm}$ ).

In FY2010 all gross alpha, nonvolatile beta and tritium results from the wells sampled around the ORWBG and MWMF were below action levels. Given the complex groundwater flow associated with the HTF, a relatively large number of locations were selected for current CA monitoring of nitrate at HTF. All groundwater locations sampled were below action levels. Two sample wells HAA 4D and HAA 11D were dry and could not be sampled. In the FY2009 these two wells exceeded the nitrate action level but were below the drinking water standard.

In FY2010 an action was taken under CA maintenance to determine if elevated nitrate concentrations at these two locations were above background nitrate or could be correlated with radionuclide migration. Actions taken in 2010 include reviewing the historical nitrate data in order to better establish a range for background nitrate concentration for HTF. Another action was to review historical data for HTF monitoring locations including nitrate data as well as a number of other analytes including gross alpha, nonvolatile beta, uranium, neptunium, Tc-99, I-129 and $\mathrm{pH}$. The nitrate concentration data were compared with other analytes at the same locations to determine whether the elevated nitrate could be correlated with any radionuclides or any other gross indicators for radionuclide migration. This review showed that well sample locations HAA 4D and 11D were elevated above background, but below drinking water standards. A review of historical data showed nitrate could not be correlated directly with any radionuclide data.

In the new revised $2010 \mathrm{CA}$ the $\mathrm{HTF}$ is no longer considered a major contributing source. Therefore, CA monitoring at such close proximity to HTF will not likely be warranted in future revisions of the CA Monitoring Plan. However, continued monitoring of these locations at the HTF Facility will continue as appropriate through SRS site programs such as the Tank Farm Monitoring Program as these facilities continue to operate and are decommissioned.

Tritium continues to be monitored as the only radionuclide expected to occur in SRS streams in the near term. In 2010 average annual tritium levels at all four stream monitoring locations remained below the action levels. The long term trend is that tritium concentrations in Four Mile Branch are decreasing.

\subsection{RESEARCH AND DEVELOPMENT}

The CA annual review has determined that there would be no changes in the conclusions of the CA as a result of R\&D activities. Specifically, as demonstrated in their respective PA Annual Reviews, all ELLWF (contained herein) and SDF (SRR, 2010a) PAs, SAs and UDQEs maintained operations within DOE 435.1 performance objectives resulting in no impact for the CA.

\subsection{CHANGES}

The new CA (SRNS, 2010c) was approved by DOE on June 10, 2010. This 2010 CA considers residuals for the entire SRS and is not limited to the GSA as in the 1997 CA. 


\subsection{RECOMMENDED CHANGES}

- Establish a formal CA maintenance program to protect key I\&A from the 2010 CA including SRS land use planning, SRS facility end state planning and residual radionuclide inventories.

- Prepare a new CA monitoring plan consistent with the points of assessment, major contributing sources and key risk driving radionuclides in the new 2010 SRS CA which has been expanded to include the entire site.

- Complete initial CA improvements identified by the LFRG review of the 2010 CA including; enhancements to the CA uncertainty analysis, updating the CA end state inventory report and expanding Lower Three Runs inventories.

- Start development of an SRS regional groundwater model identified as a need for the next CA revision by the LFRG Review Team.

- Beginning in FY2011, conduct the CA Annual Review against the new 2010 revision of the CA. 


\subsection{PERFORMANCE ASSESSMENT ANNUAL DETERMINATION}

\subsection{PERFORMANCE ASSESSMENT WASTE RECEIPTS}

A revised PA and DAS were approved and implemented in October 2008. The approved PA/SA (WSRC, 2008b) was used as a means to determine the allowable radionuclide concentrations and inventories in each type of disposal unit.

\subsubsection{Waste Receipts (Past and Future)}

The disposed radionuclide and volumetric inventory in FY2010 (between 10/01/09 and 10/01/10) was compared against the applicable PA/SA-limits and/or PA/SA-estimates for each of the LLW disposal units in E-Area. These disposal units included the (1) LAW Vault, (2) IL Vault, (3) Disposal Trenches (STs, ETs, and CIG Trenches), and the (4) NRCDAs.

\subsubsection{SOF (See Section 3.4.2.1 for explanation of SOF)}

Table 1 indicates the radionuclide inventory disposed in each of the E-Area disposal units in FY2010. 
Table 1. SOFs for E-Area Disposal Units (FY2010)

\begin{tabular}{|c|c|c|c|c|}
\hline $\begin{array}{c}\text { Type of } \\
\text { Disposal Unit }\end{array}$ & $\begin{array}{c}\text { Disposed } \\
\text { Radionuclides } \\
\text { Prior to FY2010 } \\
\text { (Curies) } \\
\end{array}$ & $\begin{array}{c}\text { Disposed } \\
\text { Radionuclides at } \\
\text { the End of FY2010 } \\
\text { (Curies) }\end{array}$ & $\begin{array}{c}\text { Percent } \\
\text { Increase in } \\
\text { FY2010 }\end{array}$ & $\begin{array}{c}\text { Most Limiting } \\
\text { SOF }^{1}\end{array}$ \\
\hline $\begin{array}{l}\text { LAW Vault } \\
\text { (Cells 1-9) }\end{array}$ & $2.50 \mathrm{E}+05$ & $3.14 \mathrm{E}+05$ & $25.5 \%^{3}$ & 0.10 \\
\hline IL Vault & $8.04 \mathrm{E}+05$ & $1.20 \mathrm{E}+06$ & $49.2 \%$ & 0.38 \\
\hline First Set of STs ${ }^{2}$ & $3.98 \mathrm{E}+01$ & $3.98 \mathrm{E}+01$ & $0.0 \%$ & 0.85 \\
\hline $\begin{array}{c}\text { Second Set of } \\
\text { STs }\end{array}$ & $1.64 \mathrm{E}+02$ & $1.64 \mathrm{E}+02$ & $0.0 \%$ & 0.87 \\
\hline Third Set of STs & $1.01 \mathrm{E}+02$ & $1.25 \mathrm{E}+02$ & $23.3 \%$ & 0.90 \\
\hline Fourth Set of STs & $3.73 \mathrm{E}+01$ & $1.40 \mathrm{E}+02$ & $276.2 \%$ & 0.99 \\
\hline Fifth Set of STs & $1.27 \mathrm{E}+05$ & $1.27 \mathrm{E}+05$ & $0.0 \%$ & 0.99 \\
\hline Sixth Set of STs & $1.09 \mathrm{E}+02$ & $1.25 \mathrm{E}+02$ & $15.0 \%$ & 0.79 \\
\hline $\begin{array}{c}\text { Seventh Set of } \\
\text { STs } \\
\end{array}$ & $4.53 \mathrm{E}+01$ & $6.64 \mathrm{E}+01$ & $46.5 \%$ & 0.63 \\
\hline Eighth Set of STs & $2.04 \mathrm{E}+01$ & $2.87 \mathrm{E}+01$ & $40.7 \%$ & 0.65 \\
\hline ET 1 & $1.82 \mathrm{E}+02$ & $2.11 \mathrm{E}+02$ & $15.9 \%$ & 0.74 \\
\hline ET 2 & $1.56 \mathrm{E}+02$ & $1.61 \mathrm{E}+02$ & $3.3 \%$ & 0.34 \\
\hline $\begin{array}{l}\text { NRCDA } \\
(643-7 E) \\
\end{array}$ & $8.00 \mathrm{E}+05$ & $8.00 \mathrm{E}+05$ & $0.0 \%$ & 0.94 \\
\hline $\begin{array}{l}\text { NRCDA } \\
(643-26 E) \\
\end{array}$ & $4.16 \mathrm{E}+05$ & $4.16 \mathrm{E}+05$ & $0.0 \%$ & 0.33 \\
\hline $\mathrm{CIG}$ & $9.39 \mathrm{E}+03$ & $9.42 \mathrm{E}+03^{4}$ & $0.4 \%$ & 0.44 \\
\hline
\end{tabular}

${ }^{1}$ For disposal units with air as the most limiting pathway, the SOF is based on the cumulative effect across all units.

${ }^{2}$ A set of STs consists of five individual trenches (typical).

${ }^{3}$ Increase in LAW Vault disposed radionuclides while reducing the disposed waste volume, using mining activities, is based on the amount of tritium disposed in FY2010.

${ }^{4}$ Slight increase in CIG disposed radionuclides while no waste disposed in FY2010 is based on waste characterization change. 


\subsubsection{Actual vs. Forecasted Radionuclide Inventory}

The FY2010 disposed radionuclide inventories are compared with the forecasted inventories for E-Area disposal units in Table 2. Forecasted radionuclide inventories were computed by multiplying the average concentration for each radionuclide derived from current disposal unit inventories by the volumetric waste forecast numbers at time of facility closure.

Table 2. FY2010 PA - Estimated Radionuclide Inventory vs. Actual \& Forecast Inventory

\begin{tabular}{|c|c|c|c|}
\hline Disposal Unit & $\begin{array}{c}\text { Actual Inventory As of } \\
\mathbf{1 0 / 0 1 / 1 0} \\
\text { (Curies) }\end{array}$ & $\begin{array}{c}\text { Forecasted Inventory } \\
\text { At Facility Closure } \\
(\mathbf{1 0 0 \%} \text { full) } \\
\text { (Curies) }\end{array}$ & $\begin{array}{c}\text { Projected } \\
\text { SOF } \\
\text { At Facility Closure } \\
\text { (100\% full) }\end{array}$ \\
\hline LAW Vault & $3.14 \mathrm{E}+05$ & $5.00 \mathrm{E}+05$ & 0.95 \\
\hline IL Vault & $1.20 \mathrm{E}+06$ & $1.00 \mathrm{E}+07$ & 0.95 \\
\hline First Set of STs ${ }^{2}$ & $3.98 \mathrm{E}+01$ & $3.98 \mathrm{E}+01^{2}$ & 0.85 \\
\hline Second Set of STs & $1.64 \mathrm{E}+02$ & $1.64 \mathrm{E}+02^{2}$ & 0.87 \\
\hline Third Set of STs & $1.25 \mathrm{E}+02$ & $1.25 \mathrm{E}+02^{2}$ & 0.90 \\
\hline Fourth Set of STs & $1.40 \mathrm{E}+02$ & $1.40 \mathrm{E}+02^{2}$ & 0.99 \\
\hline Fifth Set of STs & $1.27 \mathrm{E}+05$ & $1.27 \mathrm{E}+05^{2}$ & 0.95 \\
\hline Sixth Set of STs & $1.25 \mathrm{E}+02$ & $1.10 \mathrm{E}+03$ & 0.95 \\
\hline Seventh Set of STs & $6.64 \mathrm{E}+01$ & $1.10 \mathrm{E}+03$ & 0.95 \\
\hline Eighth Set of STs & $2.87 \mathrm{E}+01$ & $1.10 \mathrm{E}+03$ & 0.95 \\
\hline ET 1 & $2.11 \mathrm{E}+02$ & $3.90 \mathrm{E}+03$ & 0.95 \\
\hline ET 2 & $1.61 \mathrm{E}+02$ & $2.00 \mathrm{E}+03$ & 0.94 \\
\hline NRCDA (643-7E) & $8.00 \mathrm{E}+05$ & $8.00 \mathrm{E}+05^{2}$ & 0.95 \\
\hline NRCDA (643-26E) & $4.16 \mathrm{E}+05$ & $5.00 \mathrm{E}+06$ & $1.50 \mathrm{E}+07$ \\
\hline CIG & $9.42 \mathrm{E}+03$ & & 0.95 \\
\hline
\end{tabular}

${ }^{1}$ A set of Slit Trenches consists of 5 individual trenches (typical).

${ }^{2}$ No longer receiving waste. 


\subsubsection{Actual Volumetric Inventory vs. PA-Estimated}

A comparison of the actual and PA-estimated volumetric inventories of the disposed waste was made for the E-Area Vaults, disposal trenches and NRCDAs. Table 3 shows the actual waste volumes (for both stored and disposed wastes), the disposal unit capacity, and the calculated percent-filled. Waste in storage will be disposed in the future, so this analysis considers it disposed to gain a clear picture of current disposal capacity.

Table 3. FY2010 Status of ELLWF Disposal Unit Capacity

\begin{tabular}{|c|c|c|c|c|}
\hline Disposal Unit & $\begin{array}{c}\text { Disposed Volumes } \\
\text { As of 10/01/10 } \\
\mathbf{( m}^{\mathbf{3}} \mathbf{)}\end{array}$ & $\begin{array}{c}\text { PA-Estimated Disposal } \\
\text { Capacity } \\
\mathbf{( m}^{\mathbf{3}} \mathbf{(}\end{array}$ & $\begin{array}{c}\text { Percent } \\
\text { Filled } \\
\text { FY2010 } \\
\mathbf{( \% )}\end{array}$ & $\begin{array}{c}\text { Percent } \\
\text { Change since } \\
\text { FY2009 } \\
\mathbf{( \% )}\end{array}$ \\
\hline LAW Vault & 8,883 & 30,600 & 29 & $-9^{1}$ \\
\hline IL Vault & 2,183 & 4,284 & 51 & 2 \\
\hline First Set of STs & 14,264 & 14,264 & 100 & 0 \\
\hline Second Set of STs & 15,560 & 15,560 & 100 & 0 \\
\hline Third Set of STs & 16,953 & 16,953 & 100 & 11 \\
\hline Fourth Set of STs & 19,193 & 19,193 & 100 & 33 \\
\hline Fifth Set of STs & 28,125 & 28,125 & 100 & 0 \\
\hline Sixth Set of STs & 13,141 & $27,250^{2}$ & 48 & 5 \\
\hline Seventh Set \\
of STs
\end{tabular}

${ }^{1}$ Reduction of disposed volume in LAW Vault accounts for the mining effort in FY2010 in moving waste from the LAW Vault to Slit Trenches

${ }^{2}$ Revised PA estimated disposal capacity based on new projections in the field.

${ }^{3}$ Reduction in disposed volumes in ET 2 is based on the relocation of six large tanks from ET 2 to the Fourth Set of STs 


\subsubsection{Waste Types}

This section considers the waste types that have been disposed in the ELLWF. As required by the WAC (SRS, 2009), waste generators must fill out a waste stream characterization form (WSCF) for each waste stream and forward it to the Savannah River Nuclear Solutions (SRNS) SWM for approval prior to shipping. This characterization form includes the waste type and description. SWM reviews the characterization form for acceptability with the WAC. Currently, there are over 1,787 approved waste streams in WITS with 474 approved waste streams active as of the end of FY2010. A review of the characterization forms shows that the waste types listed in Table 4 have been received at the appropriate EArea disposal/storage unit. All of the waste types received in the E-Area disposal units were included and analyzed in the PA or supporting SAs.

Table 4. Disposal Unit Waste Types

\begin{tabular}{|c|c|c|c|c|c|c|c|}
\hline \multirow{3}{*}{ Waste Type } & \multicolumn{7}{|c|}{ Disposal Units } \\
\hline & \multirow{2}{*}{$\begin{array}{l}\text { LAW } \\
\text { Vault }\end{array}$} & \multirow{2}{*}{$\begin{array}{l}\text { ILNT } \\
\text { Vault }\end{array}$} & \multirow{2}{*}{$\begin{array}{c}\text { ILT } \\
\text { Vault }\end{array}$} & \multicolumn{3}{|c|}{ Trenches } & \multirow{2}{*}{ NRCDA } \\
\hline & & & & ST & ET & CIG & \\
\hline Job Control Waste & $\mathrm{X}$ & $\mathrm{X}$ & $\mathrm{X}$ & $\mathrm{X}$ & $\mathrm{X}$ & $\mathrm{X}$ & \\
\hline Construction Materials & $\mathrm{X}$ & $\mathrm{X}$ & $\mathrm{X}$ & $\mathrm{X}$ & $\mathrm{X}$ & & \\
\hline Scrap Metal & $\mathrm{X}$ & $\mathrm{X}$ & $\mathrm{X}$ & $\mathrm{X}$ & $\mathrm{X}$ & $\mathrm{X}$ & \\
\hline $\begin{array}{l}\text { Process Equipment \& } \\
\text { Auxiliary Equipment }\end{array}$ & $\mathrm{X}$ & $\mathrm{X}$ & $\mathrm{X}$ & $\mathrm{X}$ & $\mathrm{X}$ & $\mathrm{X}$ & $\mathrm{X}$ \\
\hline D\&D Debris & $\mathrm{X}$ & & & $\mathrm{X}$ & $\mathrm{X}$ & $\mathrm{X}$ & \\
\hline Soil, Rubble & $\mathrm{X}$ & & & $\mathrm{X}$ & & & \\
\hline Filter Media & $\mathrm{X}$ & $\mathrm{X}$ & $\mathrm{X}$ & $\mathrm{X}$ & $\mathrm{X}$ & & \\
\hline Vegetation/incinerator ash & $\mathrm{X}$ & $\mathrm{X}$ & $\mathrm{X}$ & $\mathrm{X}$ & $\mathrm{X}$ & & \\
\hline $\begin{array}{l}\text { Solidified liquids, sludges, } \\
\text { soils }\end{array}$ & $\mathrm{X}$ & $\mathrm{X}$ & $\mathrm{X}$ & $\mathrm{X}$ & X & $\mathrm{X}$ & \\
\hline Biological Waste & $\mathrm{X}$ & $\mathrm{X}$ & $\mathrm{X}$ & & & & \\
\hline Radioactive Sources & $\mathrm{X}$ & $\mathrm{X}$ & $\mathrm{X}$ & $\mathrm{X}$ & $X$ & $\mathrm{X}$ & \\
\hline Wood Products & $\mathrm{X}$ & $\mathrm{X}$ & $\mathrm{X}$ & $\mathrm{X}$ & $\mathrm{X}$ & & \\
\hline Crucibles & & & $\mathrm{X}$ & & & & \\
\hline
\end{tabular}

ILNT = Intermediate Level Non-Tritium Vault; ILT = Intermediate Level Tritium;

\subsection{E-AREA MONITORING PROGRAM}

This section of the PA Annual Review describes activities completed in FY2010 in support of the EMOP (Millings, 2009a). The EMOP has been in operation since 1999 and is designed to evaluate waste disposal operations versus criteria established by the facility PA (WSRC, 2008b) and the CA (WSRC, 1997). The EMOP is implemented in accordance with DOE Order 435.1. The objectives of the EMOP are: (1) to monitor trends in performance (2) to provide feedback for the PA model and (3) to evaluate the need for corrective action prior to exceeding PA performance objectives. 
In fact, the E-Area Monitoring Program is designed to allow opportunities for investigation of events to continue to gain more information as monitoring occurs. The action levels are selected based on values that are $1 / 4$ of that required to meet groundwater protection limits at the 100 meters compliance point. SWM's objective is to utilize the available radionuclide margin for trench disposal without exceeding allowable limits. Therefore, it is expected that the action levels will be exceeded. This allows a trigger to ensure that continuous evaluation of results will occur. It should be noted that action levels would have to be simultaneously exceeded by a factor of 4 over a significant portion of the trench in a number of the deepest lysimeters (closest to the aquifer) before there is a danger of exceeding groundwater drinking standards.

According to the current PA, groundwater is the most significant pathway for release from the ELLWF. Therefore, the EMOP includes the monitoring of various areas that have the potential of contributing constituents of concern to the groundwater. Sections 3.2.1 through 3.2.4 discuss and provide monitoring results for the following areas: (3.2.1) Vadose Zone, (3.2.2) Sump Water, (3.2.3) Groundwater, and (3.2.4) Vault Integrity.

Table 5 shows a summary of the monitoring plan for each of these areas (Millings, 2009a; Crapse, 2009). Table 6 provides a summary of the monitoring results from FY2010.

Table 5. PA Monitoring Plan Summary Table

\begin{tabular}{|c|c|c|c|c|}
\hline Area & $\begin{array}{l}\text { Monitoring } \\
\text { Location }\end{array}$ & $\begin{array}{l}\text { Sampling } \\
\text { Frequency }\end{array}$ & $\begin{array}{c}\text { Radionuclide/Other } \\
\text { Substance }\end{array}$ & Action Levels ${ }^{1}$ \\
\hline Vadose Zone & $\begin{array}{l}\text { Beneath and } \\
\text { adjacent to the } \\
\text { trenches }\end{array}$ & Twice per year & Tritium & $\begin{array}{c}\text { East ST }-63.8 \mathrm{pCi} / \mathrm{mL} \\
\text { Center ST }-61.2 \mathrm{pCi} / \mathrm{mL} \\
\text { West ST }-46.9 \mathrm{pCi} / \mathrm{mL} \\
\text { ET }-101.3 \mathrm{pCi} / \mathrm{mL} \\
\text { CIG }-752.0 \mathrm{pCi} / \mathrm{mL}\end{array}$ \\
\hline \multirow{3}{*}{ Sump Water } & \multirow{3}{*}{$\begin{array}{c}\text { Vault / } \\
\text { Engineered } \\
\text { Trench Sumps }\end{array}$} & \multirow{3}{*}{$\begin{array}{l}\text { Prior to pumping } \\
\text { when threshold } \\
\text { liquid levels are } \\
\text { exceeded }\end{array}$} & Gross Alpha & $\begin{array}{c}1.35 \mathrm{E}+3 \mathrm{pCi} / \mathrm{L} \\
(\text { or } \geq 3.0 \mathrm{dpm} / \mathrm{ml})\end{array}$ \\
\hline & & & Nonvolatile Beta & $\begin{array}{c}7.20 \mathrm{E}+3 \mathrm{pCi} / \mathrm{L} \\
\text { (or } \geq 16.0 \mathrm{dpm} / \mathrm{ml} \text { ) }\end{array}$ \\
\hline & & & Tritium & $\begin{array}{c}8.0 \mathrm{E}+8 \mathrm{pCi} / \mathrm{L} \\
(\text { or } \geq 1.78 \mathrm{E}+6 \mathrm{dpm} / \mathrm{ml})\end{array}$ \\
\hline \multirow{3}{*}{ Groundwater } & \multirow{3}{*}{$\begin{array}{l}\text { BGX and BGO } \\
\text { Well Series } \\
\text { bordering the } \\
\text { ELLWF }\end{array}$} & \multirow{3}{*}{ Annual } & Gross Alpha & $7.5 \mathrm{E}+2 \mathrm{pCi} / \mathrm{L}$ \\
\hline & & & Nonvolatile Beta & $1.6 \mathrm{E}+3 \mathrm{pCi} / \mathrm{L}$ \\
\hline & & & Tritium & 7.5E+7 pCi/L \\
\hline $\begin{array}{l}\text { Vault } \\
\text { Concrete / } \\
\text { Trench Cover } \\
\text { Monitoring }\end{array}$ & $\begin{array}{l}\text { Visible portions } \\
\text { of vault units; } \\
\text { subsidence } \\
\text { inspections of } \\
\text { vaults and trench } \\
\text { covers }\end{array}$ & $\begin{array}{l}\text { Periodic; per } \\
\text { latest SWM } \\
\text { procedure }\end{array}$ & $\mathrm{N} / \mathrm{A}$ & N/A \\
\hline
\end{tabular}

Sources: PA Monitoring Plan for the ELLWF (Millings, 2009a); sampling procedure for Engineered Trench Sump (SWM, 2010a); sampling procedure for the E-Area Low Level Sump (SWM, 2010b); trench cover inspection procedure (SWM, 2010e); Radiation Monitoring Procedure: Water Sample Analysis (5Q1.2, Procedure 302); Procedure 724-EAV-50 (SWM, 2010c). 
SRNS-STI-2011-00024, Revision 0

Table 6. Summary of PA Monitoring Results for FY2009

\begin{tabular}{|c|c|c|}
\hline \multirow{2}{*}{ Disposal Unit } & \multicolumn{2}{|c|}{ Monitoring Location } \\
\cline { 2 - 3 } & Action Level Lysimeters & Sump \\
\hline LAW Vault & n/a & Below Action Levels \\
\hline IL Vault & n/a & Below Action Levels \\
\hline Slit Trench 1 & $\begin{array}{c}\text { Above Action Level at one lysimeter } \\
\text { cluster (VL-26-West) }\end{array}$ & n/a \\
\hline Slit Trench 2 & Below Action Level & n/a \\
\hline Slit Trench 3 & Below Action Level \\
\hline Slit Trench 4 & Below Action Level & n/a \\
\hline Slit Trench 5 & Below Action Level & n/a \\
\hline Slit Trench 6 & Below Action Level \\
\hline Slit Trench 7 & Above Action Level at one lysimeter \\
cluster (ST7-VL-2) & n/a \\
\hline Slit Trench 8 & Below Action Level & Below Action Levels \\
\hline Engineered Trench 1 & Below Action Level & Below Action Levels \\
\hline Engineered Trench 2 & Below Action Level & n/a \\
\hline CIG Trench & Below Action Level & \\
\hline
\end{tabular}

\subsubsection{Vadose Zone Monitoring}

E Area, located in the central portion of the SRS, is the principal disposal facility for solid low-level radioactive wastes at the SRS. The disposal trenches and vaults vary in size and are typically constructed within the upper $22 \mathrm{ft}$ to $28 \mathrm{ft}$ of soil. The water table typically occurs between 65 and $79 \mathrm{ft}$ below land surface, depending on the ground surface elevations. In 1999, a vadose zone monitoring system (VZMS) was initiated to collect soil property data and soil moisture samples. As part of this program, a network of suction lysimeters was installed within the vadose zone that allow repeated sampling of soil moisture from the soil beneath and adjacent to the disposal areas. Since 1999, new lysimeters have been installed and sampled as new disposal areas were built in the ELLWF. Sampling of the lysimeters is conducted twice a year according to established site procedures (SWM, 2009b). This section summarizes new lysimeter installations, sampling results and maintenance of existing lysimeters for FY2010.

\subsubsection{Modifications to the VZMS}

Figure 1 shows the current VZMS for the STs, ETs and CIG Trenches. It also provides the locations of lysimeter clusters that were abandoned in FY2010. Table 7 provides a list of lysimeters abandoned in FY2010. The construction of the sump at ET2 resulted in the abandonment of one lysimeter cluster (ET2VL-13). Before beginning construction of the stormwater runoff covers for the STs, thirty-five lysimeter clusters were abandoned in order to avoid interferences with the stormwater runoff covers. In addition, the sampling pads of many existing clusters were modified (raised or lowered) to avoid interferences with the stormwater runoff covers. 


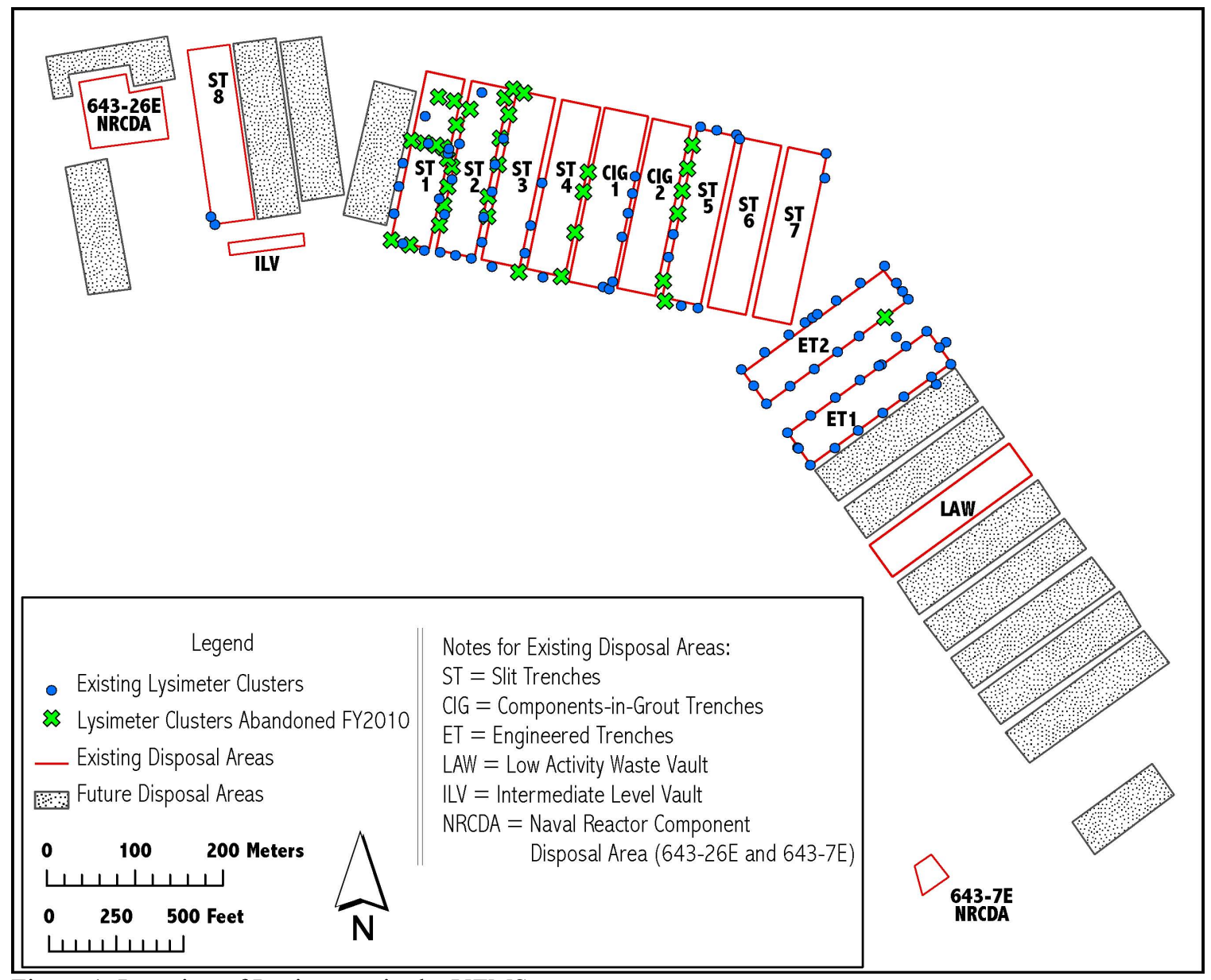

Figure 1. Location of Lysimeters in the VZMS 
SRNS-STI-2011-00024, Revision 0

Table 7. Lysimeters Abandoned in FY2010

\begin{tabular}{|c|c|c|c|c|}
\hline \multicolumn{3}{|c|}{ Lysimeter Clusters } & \multirow{2}{*}{$\begin{array}{c}\text { Location } \\
\text { Slit Trench } 1\end{array}$} & \multirow{2}{*}{$\begin{array}{c}\begin{array}{c}\text { Reason for } \\
\text { Abandonment }\end{array} \\
\begin{array}{c}\text { Construction } \\
\text { stormwater runoff } \\
\text { cover }\end{array}\end{array}$} \\
\hline $\begin{array}{l}\text { AL-1 } \\
\text { AL-2 } \\
\text { AL-3 } \\
\text { AL-4 }\end{array}$ & $\begin{array}{c}\text { AT-7 } \\
\text { AT-9 } \\
\text { AT-10 } \\
\text { VL-4 } \\
\text { VL-5 }\end{array}$ & $\begin{array}{c}\text { VL-24-South } \\
\text { VL-28-North } \\
\text { ST1-VL-2 } \\
\text { ST1-VL-3 } \\
\text { ST1-VL-4 }\end{array}$ & & \\
\hline $\begin{array}{l}\text { ST2-VL-2 } \\
\text { ST2-VL-3 }\end{array}$ & ST2-VL-5 & VL-36 & Slit Trench 2 & $\begin{array}{c}\text { Construction } \\
\text { stormwater runoff } \\
\text { cover }\end{array}$ \\
\hline $\begin{array}{l}\text { ST3-VL-1 } \\
\text { ST3-VL-2 }\end{array}$ & $\begin{array}{l}\text { ST3-VL-6 } \\
\text { ST3-VL-9 }\end{array}$ & $\begin{array}{l}\text { ST3-VL-11 } \\
\text { ST3-VL-13 } \\
\text { ST3-VL-17 }\end{array}$ & Slit Trench 3 & $\begin{array}{c}\text { Construction } \\
\text { stormwater runoff } \\
\text { cover }\end{array}$ \\
\hline ST4-VL-1 & ST4-VL-4 & $\begin{array}{l}\text { ST4-VL-6 } \\
\text { ST4-VL-7 }\end{array}$ & Slit Trench 4 & $\begin{array}{c}\text { Construction } \\
\text { stormwater runoff } \\
\text { cover }\end{array}$ \\
\hline \multirow[t]{2}{*}{$\begin{array}{l}\text { ST5-VL-3 } \\
\text { ST5-VL-4 }\end{array}$} & $\begin{array}{l}\text { ST5-VL-7 } \\
\text { ST5-VL-8 }\end{array}$ & $\begin{array}{l}\text { ST5-VL-9 } \\
\text { ST5-VL-10 }\end{array}$ & Slit Trench 5 & $\begin{array}{c}\text { Construction } \\
\text { stormwater runoff } \\
\text { cover }\end{array}$ \\
\hline & ET2-VL-13 & & $\begin{array}{c}\text { Engineered } \\
\text { Trench } 2\end{array}$ & $\begin{array}{l}\text { Construction new } \\
\text { sump }\end{array}$ \\
\hline
\end{tabular}

\subsubsection{Vadose Zone Action Levels}

The DOE Order 435.1 Performance Measure for groundwater protection is to ensure that the disposal of LLW does not cause groundwater to exceed Environmental Protection Agency (EPA) drinking water standards for radionuclides at a compliance point that is 100 meters from the disposal units. In the monitoring plan for the VZMS, tritium was selected for monitoring because its mobility makes it a good early indicator for contaminant movement. The established drinking water standard for tritium is 20 $\mathrm{pCi} / \mathrm{mL}$.

According to PA modeling predictions, elevated tritium concentrations are expected in the vadose zone beneath the ELLWF. Therefore, an action level for tritium has been established for the deep lysimeters (closest to aquifer) as a guideline to indicate whether tritium may be entering the groundwater at levels that will exceed the drinking water standard at the 100-meter compliance point.

As part of the updated PA Monitoring Plan, separate action levels have been calculated for each disposal unit grouping (e.g., East ST, Center ST, West ST and CIG Trenches and ET) (Millings, 2009a). This grouping is the same as the grouping used in the latest E-Area PA (WSRC, 2008b) and includes:

- $\quad$ East ST = "future disposal areas" east of ST7; 8 units

- $\quad$ Center ST = ST 1 through ST7; 7 units

- West ST = ST8 plus five "future disposal areas"; 6 units

- $\quad$ CIG Trenches $=2$ units

- $\quad \mathrm{ET}=2$ units

The action levels for tritium were calculated using the inventory limit for each disposal unit grouping and the peak activity concentration to the groundwater from the PA modeling. This methodology is based on that used in previous PA monitoring plans (Holmes-Burns, 1999; Cook, 2002) but takes into account the 
modeling results (including plume overlap) from the latest E-Area PA (WSRC, 2008b). Tritium activity concentrations in the deepest lysimeters (i.e., closest to the water table) are compared to the calculated action levels. Table 5 provides the calculated action levels for each disposal unit grouping.

Action level calculations incorporate several conservatisms and are meant to indicate a point in time at which further investigations should be made. A value above the calculated action level does not indicate that exceedances of the drinking water standard are expected at the compliance point. Action level lysimeters with tritium activity concentrations above their action level will be evaluated in terms of temporal, depth, and geographic occurrence to determine whether further action is needed (note: hereafter the usage of "tritium concentration" refers to "tritium activity concentration").

\subsubsection{Baseline Tritium Levels}

Baseline (or "background") tritium concentrations in the vadose zone are expected to reflect rainfall infiltration. Rainfall tritium concentrations vary both geographically between sites and temporally within a site. Examples of local, temporal and regional geographic tritium variations are shown by the minimum and maximum rainfall tritium values from the OBG at SRS between 2001 and 2009, $0.1 \mathrm{pCi} / \mathrm{mL}$ to 17.7 $\mathrm{pCi} / \mathrm{mL}$, and those of Savannah, Georgia for the same period, non-detected to $1.1 \mathrm{pCi} / \mathrm{mL}$ (SRS Annual Environmental Reports: Arnett and Mamatey, 2001; Mamatey, 2003; Mamatey, 2004; Mamatey, 2005; Mamatey, 2006; Mamatey, 2007; Mamatey, 2008; Mamatey, 2009; Mamatey, 2010).

Historically, a vadose zone "background" value of $10 \mathrm{pCi} / \mathrm{ml}$ has been used in SRS E-Area related documents, such as the FY2009 Annual Review ELLWF PA and CA (Swingle et al, 2010). This value was derived based on historical rainfall tritium concentrations near E-Area. The OBG is located adjacent to EArea, thus its rainfall tritium values can serve as proxy for E-Area proper. Tritium concentrations in rainfall at E Area are expected to be higher than in a non-anthropogenically affected area because of the nearby Tritium Facility.

The mean, minimum and maximum OBG rainfall tritium concentrations for the 8-year period from 2001 to 2009 are $3.8 \mathrm{pCi} / \mathrm{mL}, 0.1 \mathrm{pCi} / \mathrm{mL}$, and $17.7 \mathrm{pCi} / \mathrm{mL}$, respectively. Because vadose zone tritium concentrations could reflect the entire range of rainfall concentrations, depending on sampling depth and rainfall events, the $10 \mathrm{pCi} / \mathrm{mL}$ value appears reasonable as a baseline value against which to compare tritium samples from the vadose zone. It is important to note that the baseline tritium concentration is provided as a reference point for comparison with the lysimeter monitoring results. Tritium concentrations greater than $10 \mathrm{pCi} / \mathrm{mL}$ in the deep lysimeters are expected due to operation of the disposal areas at the ELLWF. Action level lysimeters with tritium concentrations above $10 \mathrm{pCi} / \mathrm{mL}$ will be noted in the annual review to check for trends and for tritium concentrations that approach the Action Level. Action Level lysimeters are defined as the deepest lysimeters (i.e., closest to the water table) (Millings, 2009a).

\subsubsection{Monitoring Results for the Action Level Lysimeters}

Results of the monitoring program indicate that the tritium concentrations in the Action Level lysimeters are below the Action Levels at all of the disposal units except for one lysimeter at ST1 (VL-26-West) and one lysimeter at ST7 (ST7-VL-2).

ST7-VL-2 is a relatively new lysimeter cluster with little data. Since its installation, tritium concentrations in this action level lysimeter have hovered near the action level. No elevated tritium has been observed in the shallow lysimeters at this cluster or in any of the lysimeters at the adjacent clusters. As with VL-26West, a hierarchical approach will be taken to investigate these data. This approach will likely include reviewing data from adjacent lysimeter clusters along with assessing existing knowledge about the geology and disposal history for the specific areas.

Figure 2 through Figure 10 show tritium concentrations in the Action Level lysimeters in relation to the specified Action Levels at the STs, ETs and CIG Trenches. 
SRNS-STI-2011-00024, Revision 0

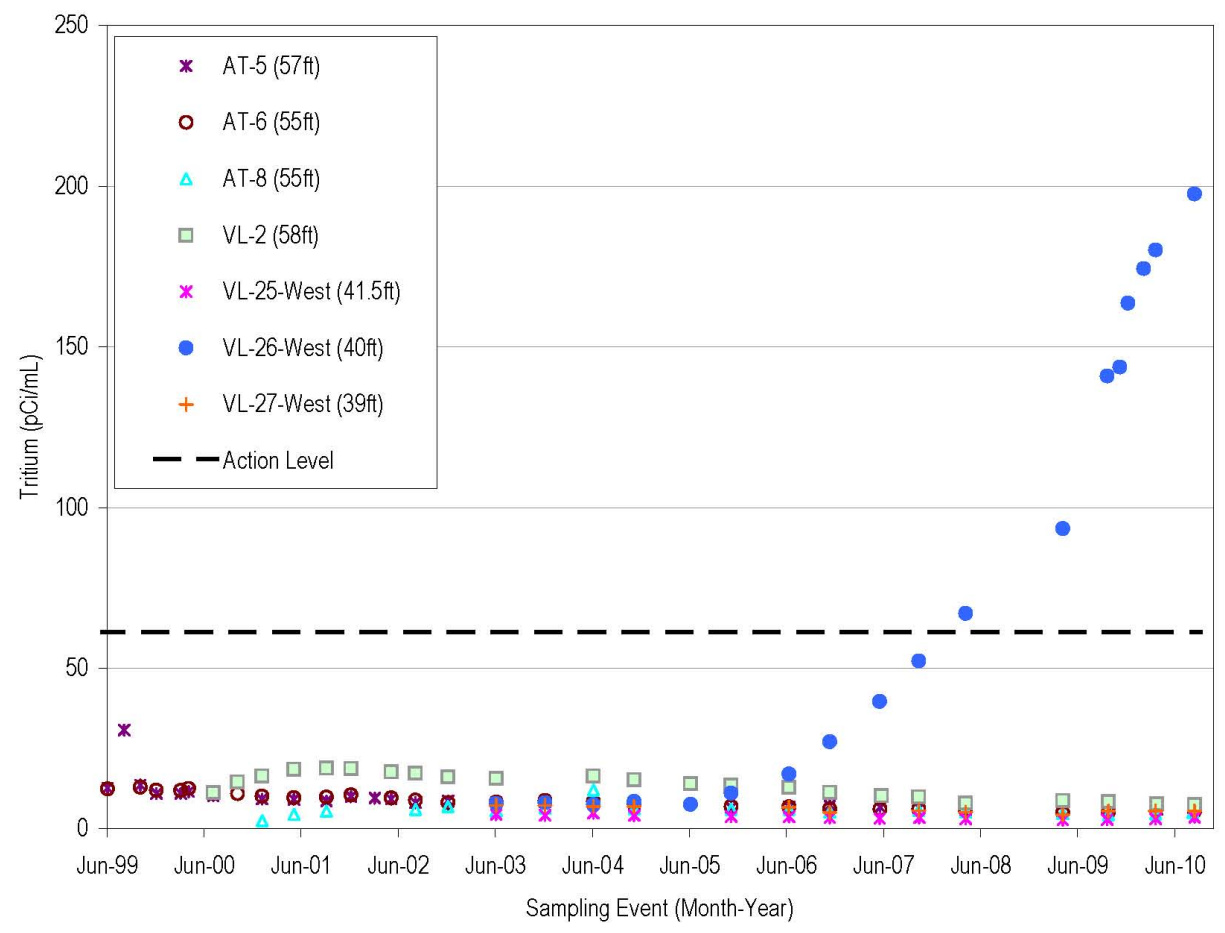

Figure 2. Concentration in Action-Level Lysimeters at ST1

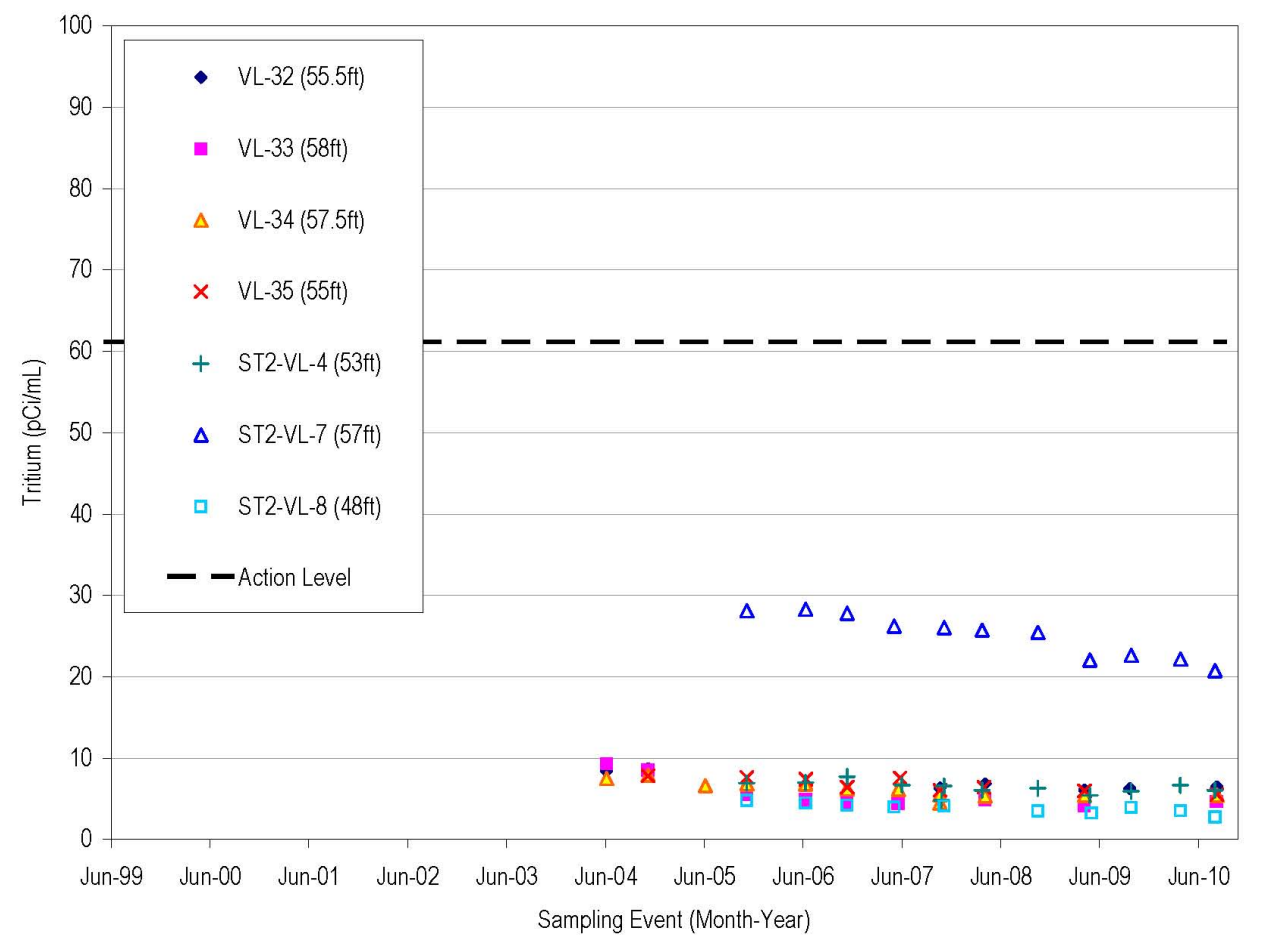

Figure 3. Tritium Concentrations in Action-Level Lysimeters at ST2 
SRNS-STI-2011-00024, Revision 0

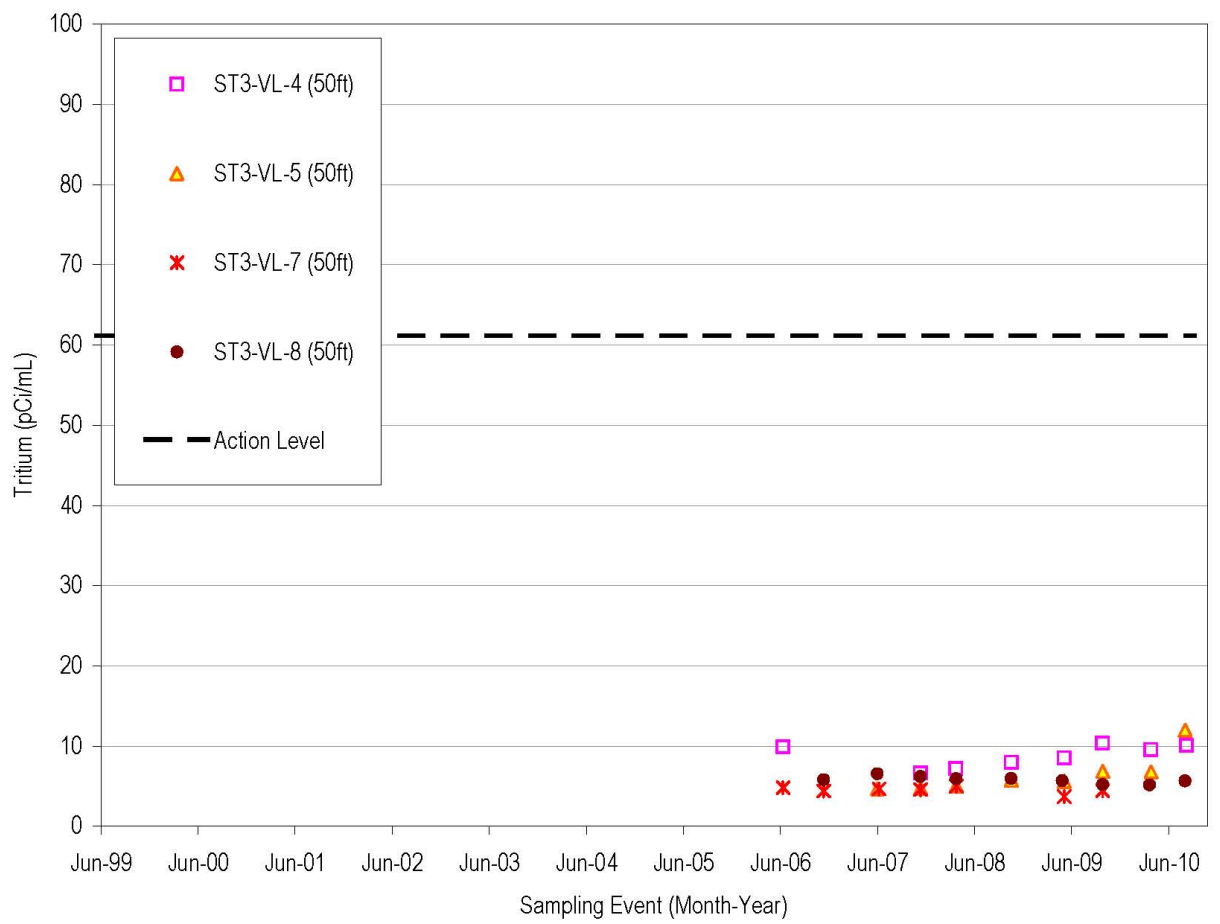

Figure 4. Tritium Concentrations in Action-Level Lysimeters at ST3

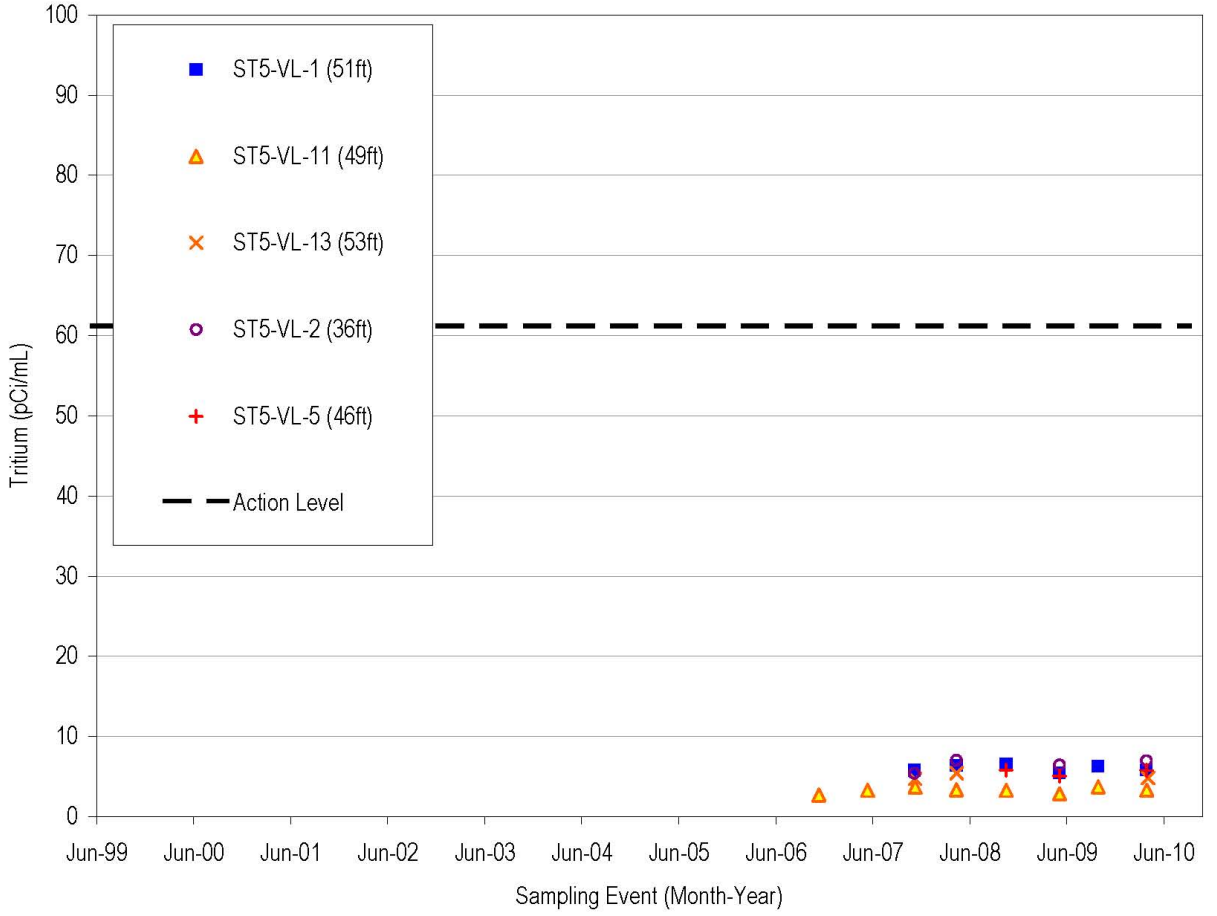

Figure 5. Tritium Concentrations in Action-Level Lysimeters at ST5 
SRNS-STI-2011-00024, Revision 0

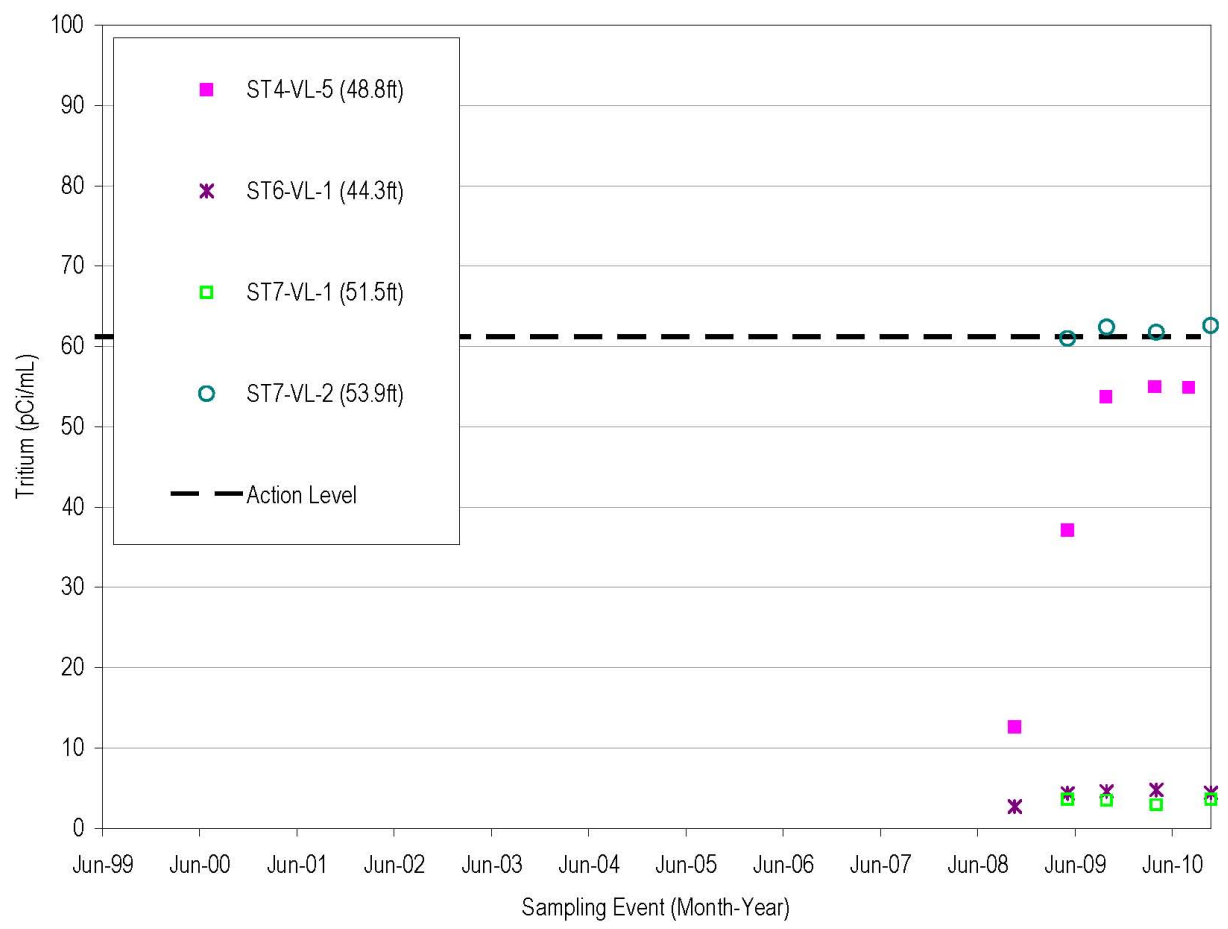

Figure 6. Tritium Concentrations in Action-Level Lysimeters at STs 4, 6 \& 7

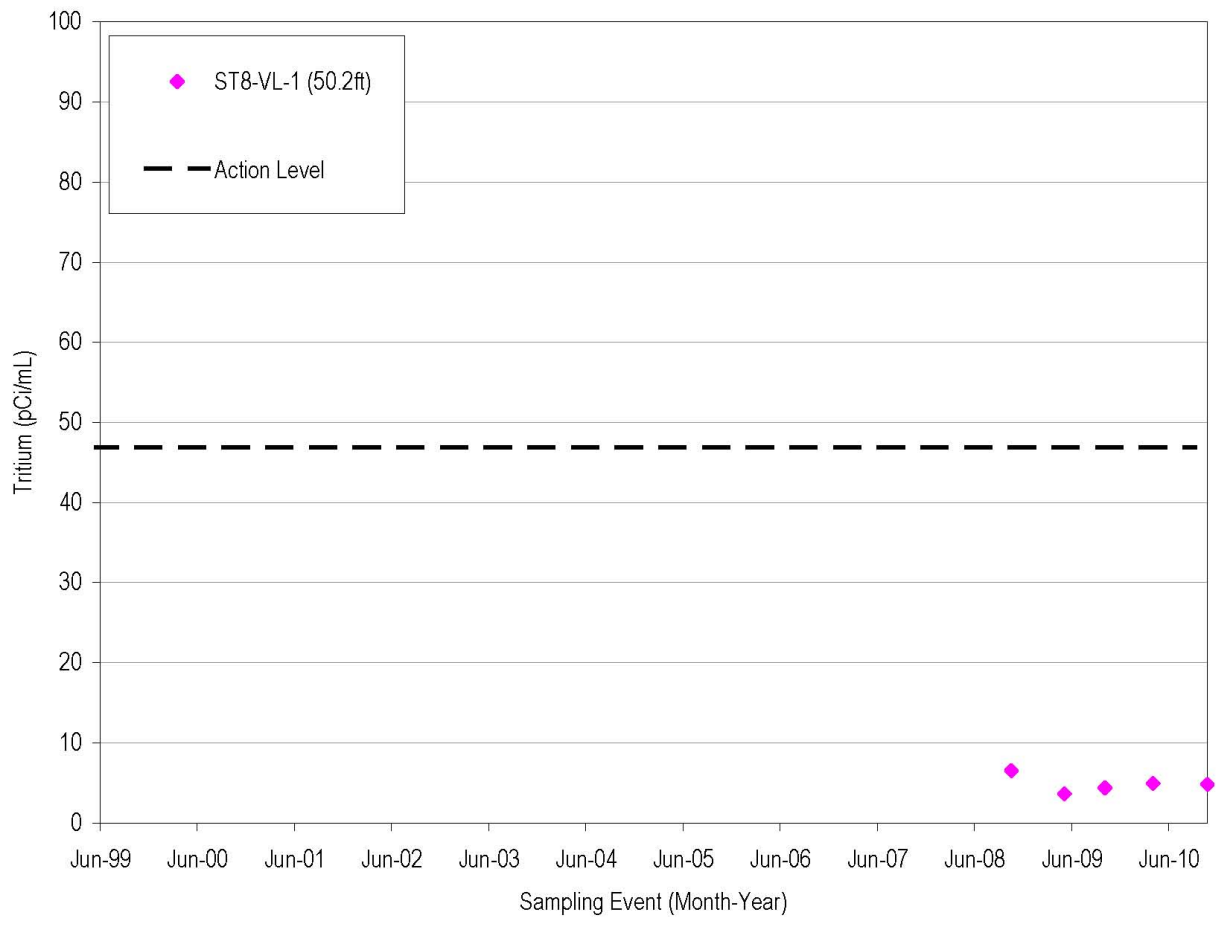

Figure 7. Tritium Concentrations in Action-Level Lysimeters at ST 8 


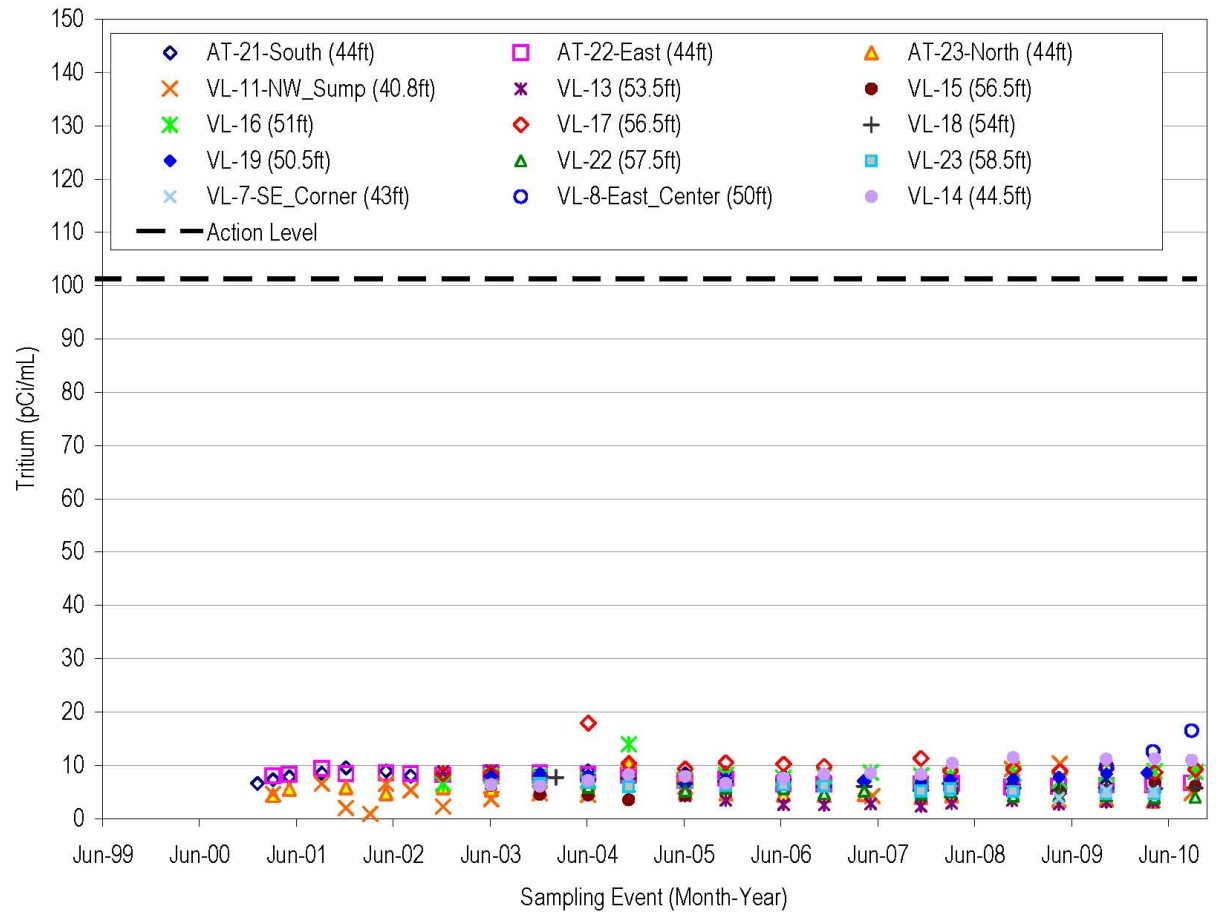

Figure 8. Tritium Concentrations in Action-Level Lysimeters at ET1

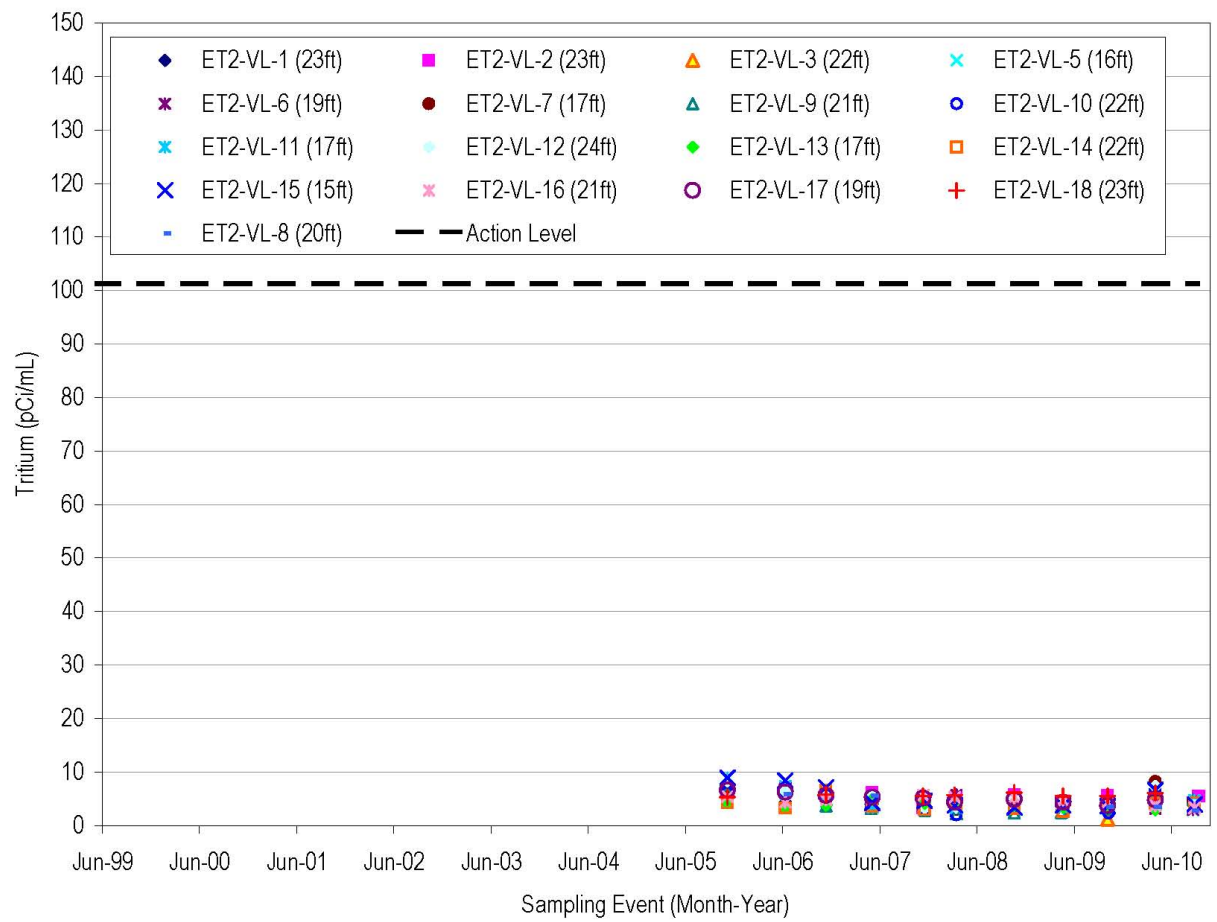

Figure 9. Tritium Concentrations in Action-Level Lysimeters at ET2 
SRNS-STI-2011-00024, Revision 0

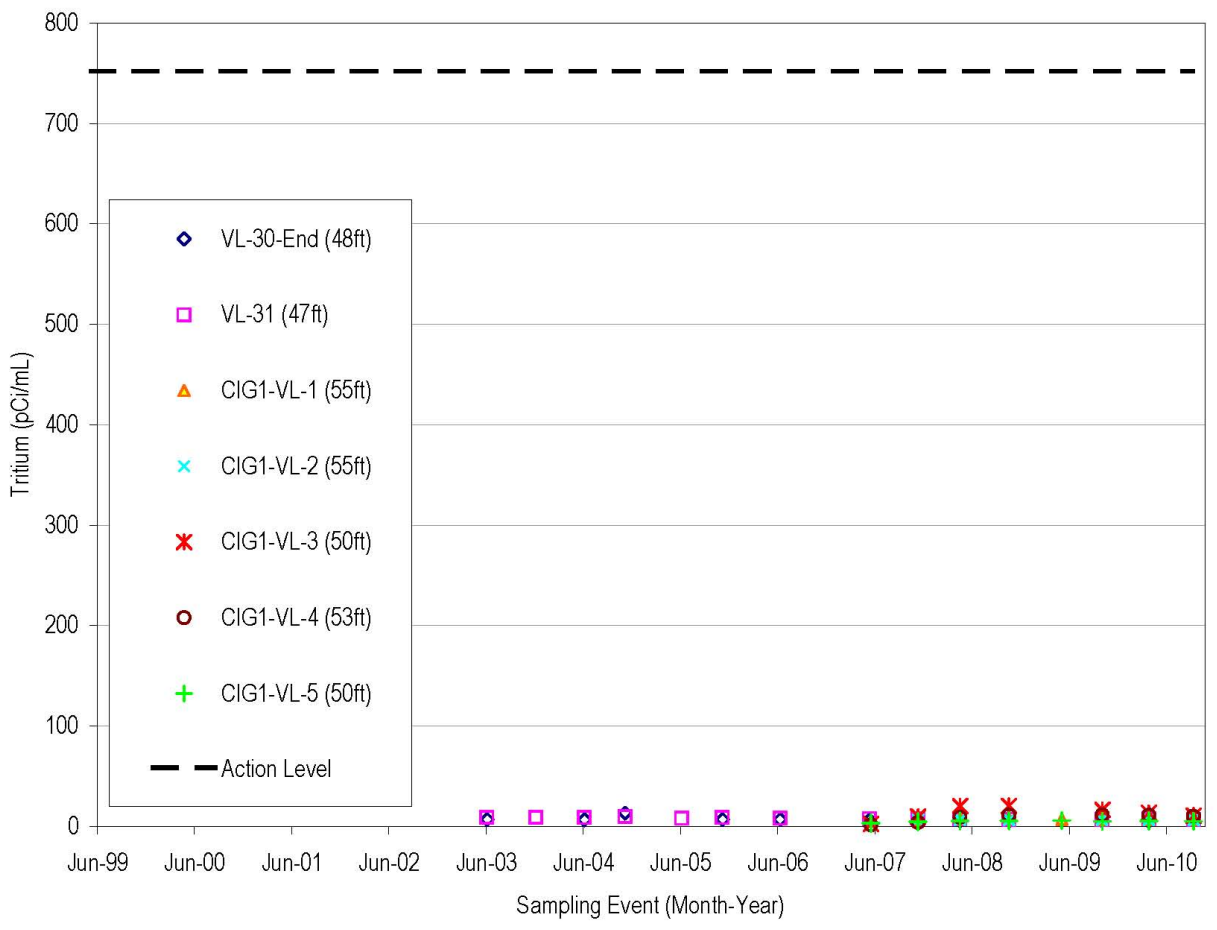

Figure 10. Tritium Concentrations in Action-Level Lysimeters at CIG Trench

Most of the action level lysimeters had tritium concentrations near or below the $10 \mathrm{pCi} / \mathrm{mL}$ baseline tritium concentration. Nine of the action level lysimeters had tritium concentrations greater than $10 \mathrm{pCi} / \mathrm{mL}$ during the last annual sampling event (Fall 2009 and Spring 2010). Table 8 provides the lysimeter names and tritium concentrations for these lysimeters. Tritium concentrations in these lysimeters will be reviewed and compared with the Action Level as new data is acquired. Comparisons with results from last FY are provided on the table in the comment column. In most cases, the data for this past year of sampling are similar to previous data. Several exceptions are noted and include ST4-VL-5, ST7-VL-2 and VL-26-West. ST4-VL-5 and ST7-VL-2 are relatively new lysimeter clusters with two years of data now available. A hierarchical approach will be taken to investigate these data. This approach will likely include reviewing data from adjacent lysimeter clusters along with existing knowledge about the geology and disposal history for the specific areas. In FY2010, a field characterization study for VL-26-West was conducted. Results from this study are provided below.

\subsubsection{VL-26 Field Characterization}

As noted in the last annual PA monitoring report (Swingle et al., 2010), tritium activity in the VL-26 action level lysimeter began exceeding its action level in 2008. In contrast, little tritium has been observed in the adjacent clusters (VL-25 and VL-27).

As outlined in the PA Monitoring Plan (Millings, 2009a), action levels are designed to serve as conservative markers to indicate when further review is needed. Recent updates to the PA model (WSRC, 2008b) and PA Monitoring Plan (Millings, 2009a) have generated lower action levels (a decrease from 100 $\mathrm{pCi} / \mathrm{mL}$ to $61.2 \mathrm{pCi} / \mathrm{mL}$ for ST 1). Multiple conservatisms are built into the action level such as 1) the establishment of an action level at $1 / 4$ of the limiting water table concentration that would produce an exceedance at the 100-meter well and 2) the assumption that all points beneath the trenches attain the peak flux calculated by the model in order to achieve the maximum contaminant level (MCL) at the 100-meter well.

Tritium concentrations in the action level lysimeter at VL-26-West are above the action level of 61.2 $\mathrm{pCi} / \mathrm{mL}$, however the concentrations are still below the limiting water table concentration that would 
SRNS-STI-2011-00024, Revision 0

produce an exceedance of performance measures at the 100-meter well. The conservative establishment of an action level at $1 / 4$ of the limiting water table concentration means that the flux to the water table would have to be $244.8 \mathrm{pCi} / \mathrm{mL}(61.2 \mathrm{X} 4)$ to exceed the MCL at the 100 -meter well. The second conservatism assumes that this flux is being generated at all points beneath the trenches in order to exceed the MCL at the 100-meter well. However, data from the adjacent lysimeters suggest no nearby extensive tritium source to the north or south of VL-26-West. The ST footprint to the west of VL-26-West does not yet contain any disposed waste. Therefore, the source of elevated tritium in VL-26-West is almost certainly to the east from disposal in ST 1 segments and is not widespread enough to affect the adjacent clusters (VL25-West and VL-27-West). Since the nearby lysimeters and other lysimeters at ST 1 do not show values above the action level, all points beneath the trenches are not producing the flux to the water table required to exceed the MCL at the 100-meter compliance well.

Once a value is detected above an action level, a hierarchical approach is recommended to evaluate the situation. As noted in the previous annual PA report, several actions were initiated to address the tritium activity concentrations at VL-26-West (Swingle et al., 2010). These initial actions included a review of existing data for VL-26-West (e.g., tritium data, geology, and disposal history) (Millings, 2009b) and onedimensional (GoldSim) modeling using existing data (Smith, 2009). One dimensional vadose zone modeling was employed to attempt a match with vadose zone well tritium concentrations and trench source terms. This effort will be followed up with three dimensional modeling.

As a follow-up to these early actions, a field study was performed in March 2010 to investigate elevated tritium activity in the lower lysimeters at the VL-26 cluster (Millings et al, 2010). The VL-26 field characterization entailed drilling two vertical boreholes and two angled boreholes. Vertical borehole EVZ-1 was completed into the water table, to a total depth of $101 \mathrm{ft}$ below land surface (bls). The core from this borehole was visually described and sampled for analyses of tritium and water content. Groundwater samples from this borehole were analyzed for tritium, iodine-129 and cobalt-60. Vertical core EVZ-2 was drilled to collect six Shelby tubes for soil property analyses. Angled borings EVZ-3 and EVZ-4 were completed underneath ST1 near VL-26, collecting sediment samples for tritium, iodine-129, cobalt-60 and soil moisture analyses. All boreholes were grouted to the surface upon completion of sampling.

This characterization revealed an area of localized tritium in the vadose zone, approximately 26 to $33 \mathrm{ft}$ bls and immediately adjacent to the ST wall. In two groundwater samples collected from borehole EVZ-1, tritium activities were within the documented range for the Lower Aquifer Zone (LAZ) plume that emanates from the adjacent Mixed Waste Management Facility/Low-Level Radioactive Waste Disposal Facility. Cobalt-60 and iodine-129 were not detected in groundwater or soil samples analyzed as part of this effort.

Soil properties from EVZ-2 Shelby tubes are consistent with the dual-layer vadose zone documented by Phifer et al. (2006). Characterization at EVZ-1 confirms that the water table currently occurs at about $77 \mathrm{ft}$ bls; this is beneath the Tan Clay Confining Zone (TCCZ), which in this area is a 5.5-ft thick competent clay occupying the zone 61.5 to $67 \mathrm{ft}$ bls. Locally, the TCCZ acts as a confining layer impeding flow from the vadose zone into the groundwater.

The soil and water analyses indicate that the tritium emanating from ST 1 near VL-26 is fairly localized and has had no discernable effect on groundwater near the ST. 
SRNS-STI-2011-00024, Revision 0

Table 8. Action Level Lysimeters with Tritium Concentrations $>10 \mathrm{pCi} / \mathrm{mL}$ in FY2010

\begin{tabular}{|c|c|c|c|c|c|c|}
\hline Station ID & $\begin{array}{c}\text { Lysimeter } \\
\text { Depth } \\
\text { ft bls } \\
\text { (Elevation } \\
\text { ft msl) }\end{array}$ & $\begin{array}{c}\text { Fall } \\
2009 \\
\text { Tritium } \\
\text { (pCi/mL) }\end{array}$ & $\begin{array}{c}\text { Spring } \\
2010 \\
\text { Tritium } \\
\text { (pCi/mL) }\end{array}$ & $\begin{array}{l}\text { General } \\
\text { Location } \\
\text { of Station }\end{array}$ & Comment & $\begin{array}{c}\text { Action } \\
\text { Level } \\
(\mathbf{p C i} / \mathbf{m L})\end{array}$ \\
\hline CIG1-VL-3 & $\begin{array}{c}50 \mathrm{ft} \\
(233 \mathrm{ft} \mathrm{msl})\end{array}$ & 16.3 & 13.5 & $\begin{array}{c}\text { CIG } \\
\text { Trench }\end{array}$ & $\begin{array}{c}\text { Concentration of } \\
20.8 \mathrm{pCi} / \mathrm{mL} \\
\text { FY2009 }\end{array}$ & 752.0 \\
\hline CIG1-VL-4 & $\begin{array}{c}53 \mathrm{ft} \\
(232 \mathrm{ft} \mathrm{msl})\end{array}$ & 11.1 & 10.8 & $\begin{array}{c}\text { CIG } \\
\text { Trench }\end{array}$ & $\begin{array}{c}\text { Concentration of } \\
10.9 \mathrm{pCi} / \mathrm{mL} \\
\text { FY2009 } \\
\end{array}$ & 752.0 \\
\hline $\begin{array}{l}\text { VL-8-East } \\
\text { Center }\end{array}$ & $\begin{array}{c}50 \mathrm{ft} \\
(234.9 \mathrm{ft} \\
\mathrm{msl})\end{array}$ & 9.8 & 12.6 & ET1 & No historical data & 101.3 \\
\hline VL-14 & $\begin{array}{c}44.5 \mathrm{ft} \\
(239 \mathrm{ft} \mathrm{msl})\end{array}$ & 11.1 & 11.2 & ET1 & $\begin{array}{c}\text { Concentration of } \\
11.4 \mathrm{pCi} / \mathrm{mL} \\
\text { FY2009 }\end{array}$ & 101.3 \\
\hline $\begin{array}{l}\text { VL-26- } \\
\text { West }\end{array}$ & $\begin{array}{c}40 \mathrm{ft} \\
(245 \mathrm{ft} \mathrm{msl})\end{array}$ & 140.9 & 180.1 & ST 1 & $\begin{array}{c}\text { Concentration of } \\
93.4 \mathrm{pCi} / \mathrm{mL} \\
\text { FY2009 }\end{array}$ & 61.2 \\
\hline ST2-VL-7 & $\begin{array}{c}57 \mathrm{ft} \\
(231 \mathrm{ft} \mathrm{msl})\end{array}$ & 22.6 & 22.2 & ST 2 & $\begin{array}{l}\text { Concentrations of } \\
25.4 \text { and } 22.0 \\
\text { pCi } / \text { mL FY } 2009\end{array}$ & 61.2 \\
\hline ST3-VL-4 & $50 \mathrm{ft}$ & 10.4 & 9.8 & ST 3 & $\begin{array}{c}\text { Concentrations of } \\
8.0 \text { and } 8.5 \mathrm{pCi} / \mathrm{mL} \\
\text { FY2009 }\end{array}$ & 61.2 \\
\hline ST4-VL-5 & $\begin{array}{c}48.8 \mathrm{ft} \\
(238 \mathrm{ft} \mathrm{msl})\end{array}$ & 53.7 & 55.0 & ST 4 & $\begin{array}{c}\text { Concentrations of } \\
12.6 \text { and } 37.1 \\
\text { pCi/mL FY2009 }\end{array}$ & 61.2 \\
\hline ST7-VL-2 & $\begin{array}{c}53.9 \mathrm{ft} \\
(231.7 \mathrm{ft} \\
\mathrm{msl})\end{array}$ & 62.4 & 61.7 & ST 7 & $\begin{array}{c}\text { Concentration of } \\
61.0 \mathrm{pCi} / \mathrm{mL} \\
\text { FY2009 }\end{array}$ & 61.2 \\
\hline
\end{tabular}




\subsubsection{Sump Water}

\subsubsection{ELLWF Vault / ET Sump Monitoring Program}

Analyses of samples taken from the vault and trench sumps are intended as a method to provide an "early warning" of contaminant releases before they exit the vault environment and enter the vadose zone, the water table and underlying aquifer units. SWM monitors the vault sumps through procedure SW15.1-SOPLLS-01, E-Area Low Level Sump Sampling and Pumping (U) and the ET sump through procedure SW15.1SOP-ESUMP-01, Engineered Trench Sump Sampling and Pumping (U) (SWM, 2010b; SWM, 2010a).

These procedures provide instructions for sampling and pumping the vaults and ET sumps. The sumps are checked for liquid levels and if liquid level thresholds are exceeded the contents are sampled for evaluation against beta-gamma, alpha and tritium limits at a minimum. The current Response (or Release) Limits are to be less than or equal to three (3) dpm/mL alpha, sixteen (16) dpm/mL beta-gamma and $1.78 \mathrm{E}+06$ $\mathrm{dpm} / \mathrm{mL}$ tritium. If the sample does not exceed any of these parameter limits, the sump contents are pumped to an outfall near the facility. If the sample exceeds one of these parameter limits, then resampling is performed. If the resampling results also exceed limits, then these procedures require SWM Low Level Waste Engineering, SWM Radiological Control Operations and SWM Environmental Compliance to be contacted for further guidance. Such guidance can involve an action plan to address the specific sump's contents.

\subsubsection{Sump Data and Conclusions}

The "Response Limits" of the sump sampling procedure discussed above and provided in Table 5 serve as the Action Levels for the sump monitoring. The results of the FY2010 ELLWF Sump Monitoring Program showed thirty-two (32) separate samples were taken from the ET sump and ten (10) separate samples from the sumps at the LAW Vault and IL Vault. All sample results were below the Action Levels. As part of standard operational routine, sump water will continued to be monitored to identify trends and ensure compliance with discharge limits. In FY2010, a new sump was constructed for ET2 which will replace the sump in ET1. ET1 sump will be closed along with the closure of ET1. At the end of FY2010, the ET2 sump was not ready for operation. ET1 and its sump are planned for closure in FY2011.

\subsubsection{Groundwater Monitoring}

\subsubsection{Groundwater Monitoring Program}

The ELLWF operating facilities are governed by the WAC derived from the PA and other requirements. Operating in this manner assures that groundwater radionuclide concentrations due to the current operation will not approach regulatory limits. Groundwater and vadose zone monitoring are performed to verify ELLWF environmental protection performance. The monitoring approaches are described in the PA Monitoring Plan for the ELLWF (Millings, 2009a).

The ELLWF is sited down-gradient of an older disposal facility, the MWMF, that was operated without the benefit of performance-based disposal limits and is the source of a tritium plume extending beneath portions the ELLWF. Therefore, groundwater monitoring data from the ELLWF perimeter wells is evaluated with respect to the Action Levels developed for the CA Monitoring Plan (Crapse, 2009). Locations of the ELLWF perimeter wells are shown on Figure 11. Action levels are provided on Table 9. The action levels specified by the CA Monitoring Plan are based on $25 \%$ of the projected peak groundwater concentrations for gross alpha, nonvolatile beta, and tritium beneath the MWMF as calculated in the CA (Crapse, 2009). A value above these Action Levels in the wells adjacent to the ELLWF would prompt further investigation as to the cause or source of the measured value whether from the MWMF or from the ELLWF. 
The MWMF and ELLWF are located near a groundwater divide. Figure 12 depicts the downward and lateral flow to either side of the groundwater divide that results from the topographic ridge along which the ELLWF and MWMF are located. Shallow groundwater beneath the Old Radioactive Waste Burial Ground (ORWBG) flows southerly, toward Fourmile Branch. Shallow groundwater beneath the ELLWF and MWMF flows northerly, toward Upper Three Runs.

Near the groundwater divide, the water table occurs in the Upper Aquifer Zone (UAZ). As the water table flows northerly away from the divide, the water table drops in elevation below the TCCZ and is then part of the LAZ. Some of the water table wells near the perimeter of the ELLWF are screened in the UAZ and some are screened in the LAZ depending on their location. The tritium plumes from the MWMF are found in the both the UAZ and LAZ underneath the ELLWF.

Figure 13 and Figure 14 depict regional tritium plumes in the UAZ and LAZ to the north and south of the groundwater divide. Figure 15 and Figure 16 show the tritium plumes in the UAZ and LAZ from beneath the closed and capped MWMF moving to the north beneath the ELLWF. Colors designate approximate plume concentrations with orange representing groundwater concentrations greater than $10,000 \mathrm{pCi} / \mathrm{mL}$, green representing concentrations $1,000-10,000 \mathrm{pCi} / \mathrm{mL}$, blue representing concentrations $100-1,000$ $\mathrm{pCi} / \mathrm{mL}$ and yellow representing concentrations $20-100 \mathrm{pCi} / \mathrm{ml}$. Red numbers provide the tritium values in $\mathrm{pCi} / \mathrm{mL}$; "NS" indicates that a well was not sampled. These plume maps are based on $3^{\text {rd }}$ quarter 2009 groundwater data from the GSA and are documented in the most recent Annual Corrective Action Report for the F Area Hazardous Waste Facility, H Area Hazardous Waste Facility and Mixed Waste Facility (SRNS, 2010b). It is important to note that the tritium plume emanating from the MWMF flows under parts of the ETs, STs, and CIG Trenches. Tritium concentrations in the groundwater can potentially affect tritium levels observed in the lower lysimeters if the lysimeters are located near or in the water table. As part of the current monitoring program, if tritium is detected in the lower lysimeters at levels above the action level, further investigation is conducted to attempt to determine the source of the tritium, either from the existing MWMF plume or from the ELLWF.

\subsubsection{Evaluation of Groundwater Data}

Perimeter well data (i.e., BGO-D and BGX-D series wells) were less (in some cases, orders of magnitude less) than the corresponding Action Levels shown in Table 9 for monitored radionuclides: gross alpha, nonvolatile beta, and tritium. 


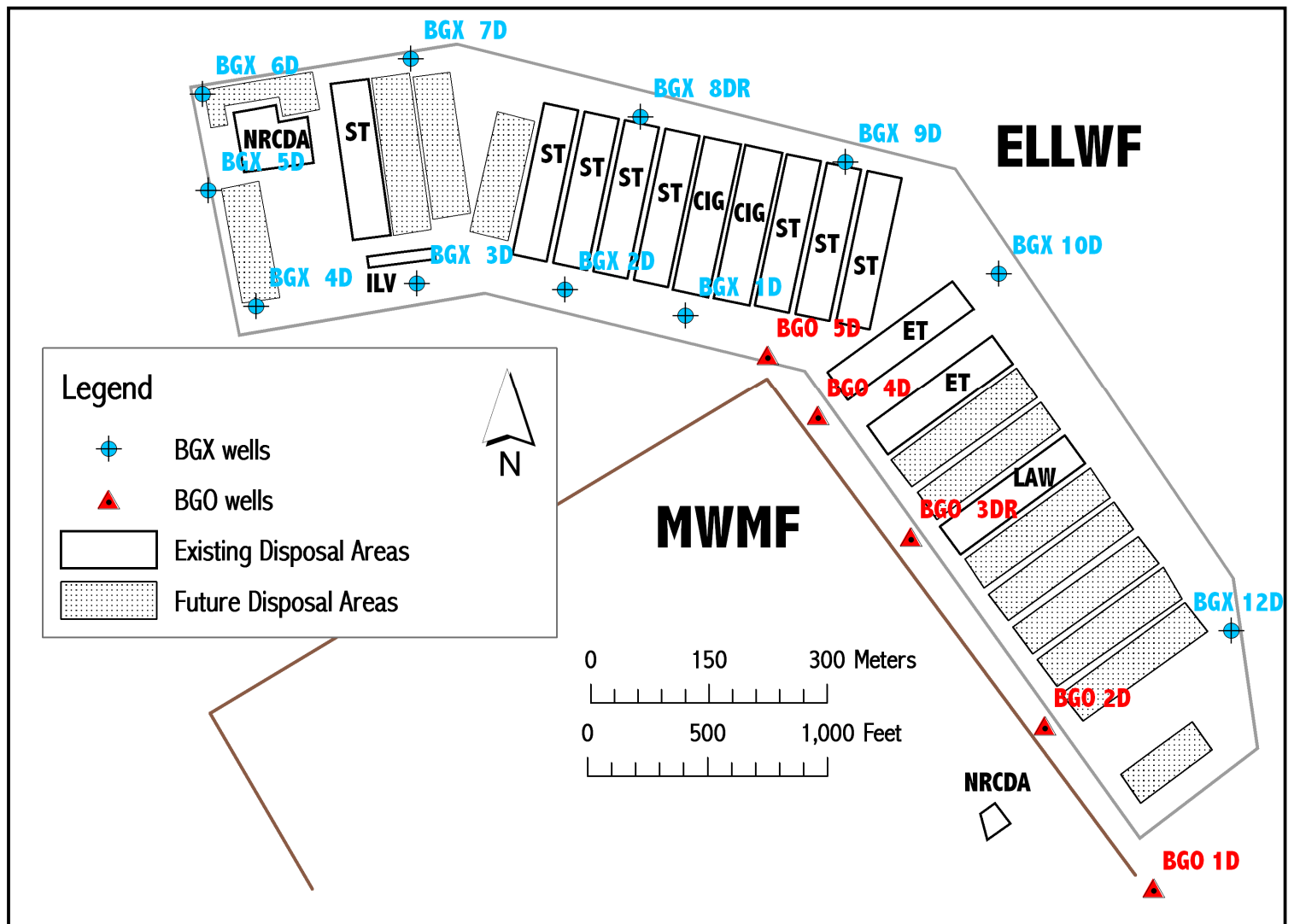

Figure 11. Map of the BGO and BGX Water Table Wells in E-Area Vicinity 


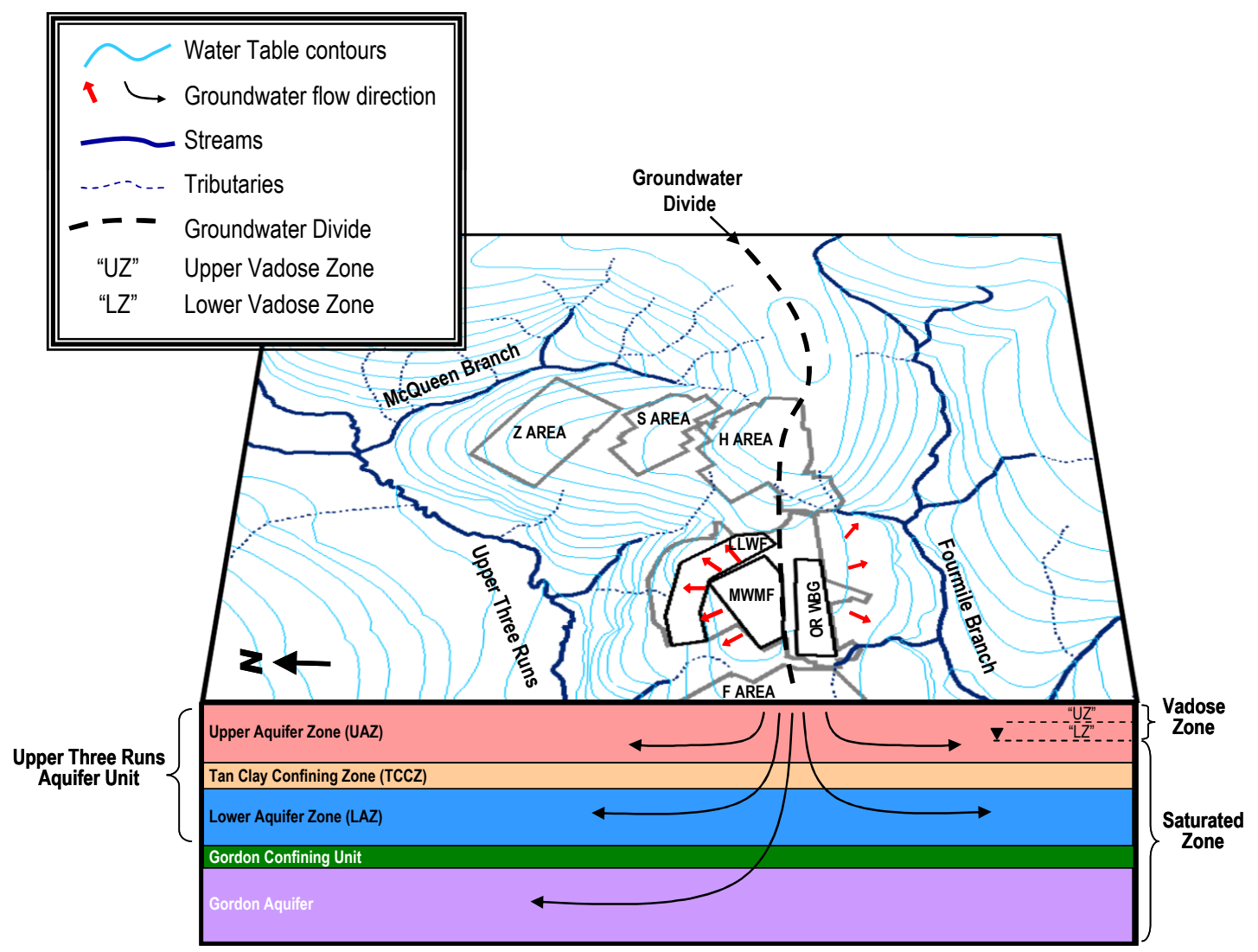

Figure 12. Groundwater Divide and Shallow Groundwater Flow Directions in E-Area Vicinity 


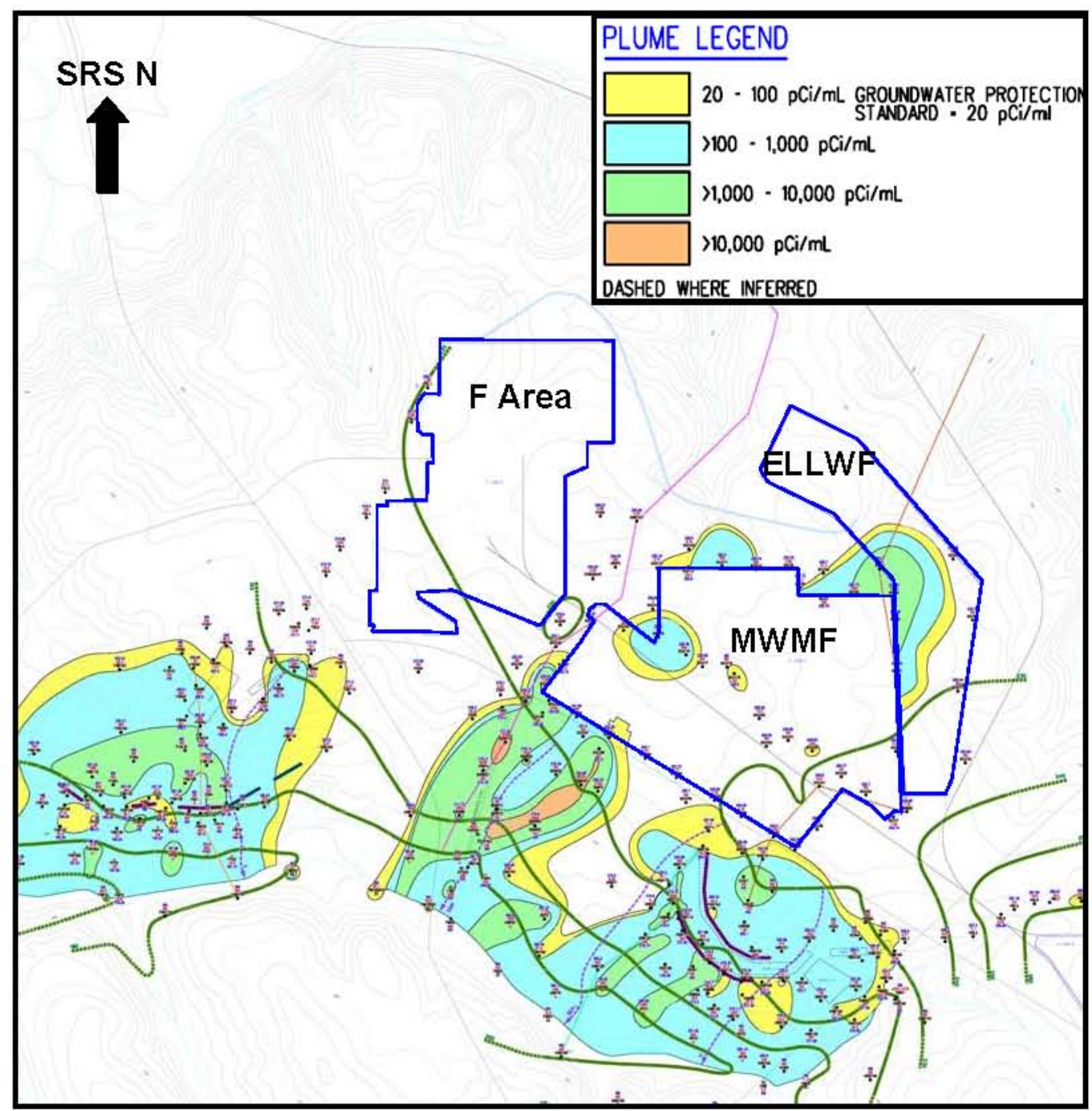

Figure 13. E-Area Vicinity Tritium Plumes Moving to North and South Sides of Groundwater Divide in UAZ 


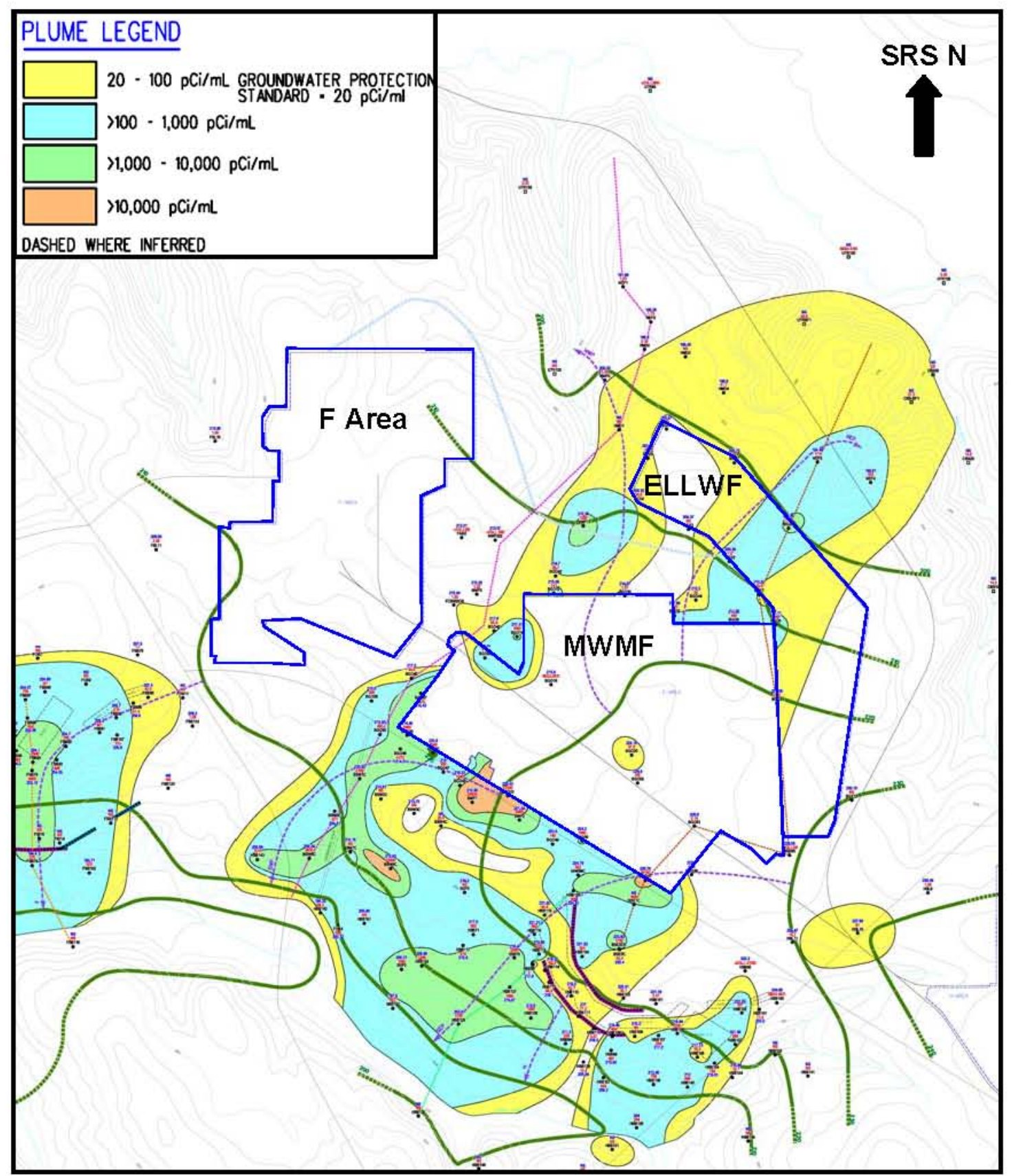

Figure 14. E-Area Vicinity Tritium Plumes Moving to North and South Sides of Groundwater Divide in Lower Aquifer Zone 
SRNS-STI-2011-00024, Revision 0

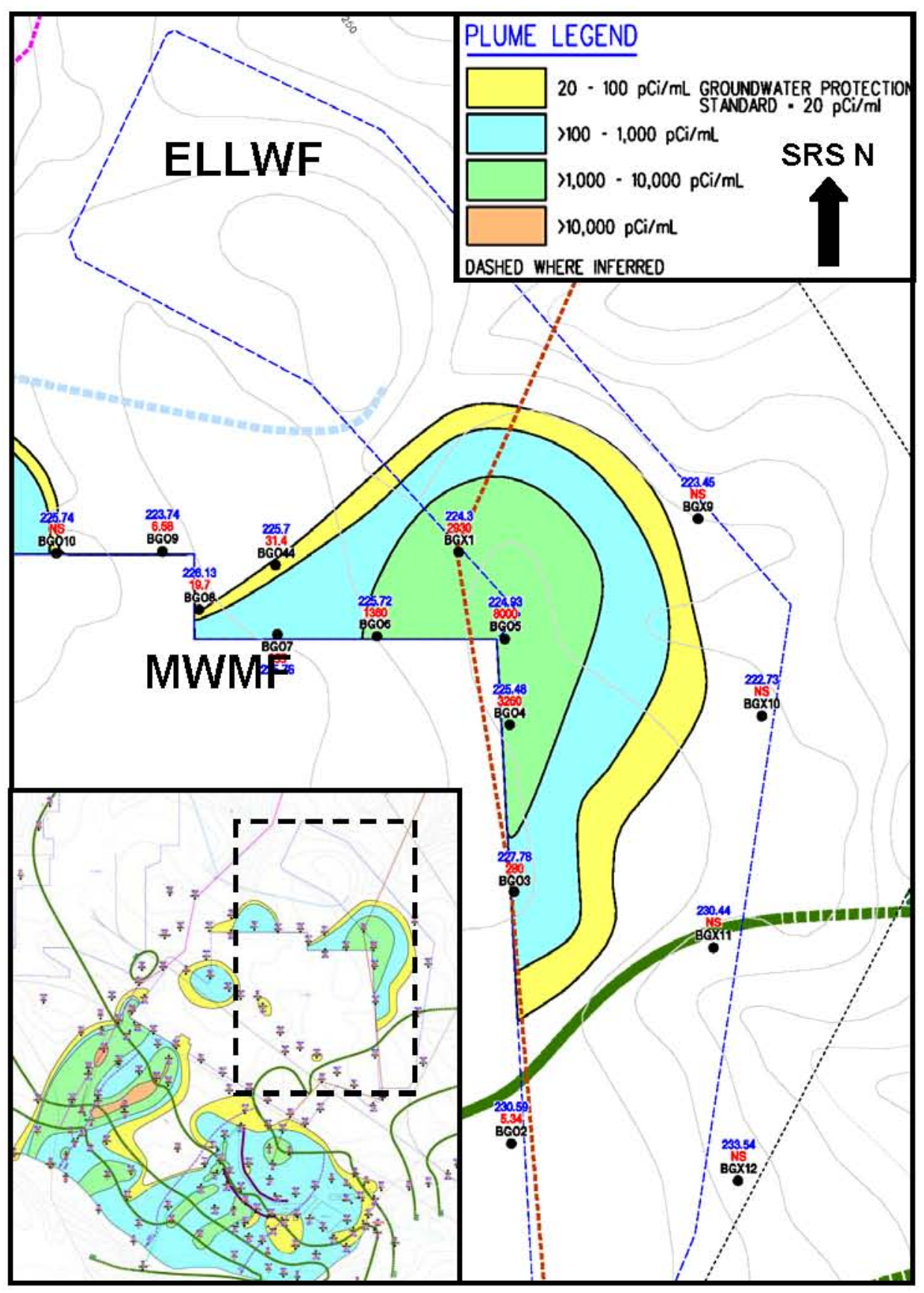

Figure 15. Tritium Plumes Moving from MWMF to ELLWF in UAZ 


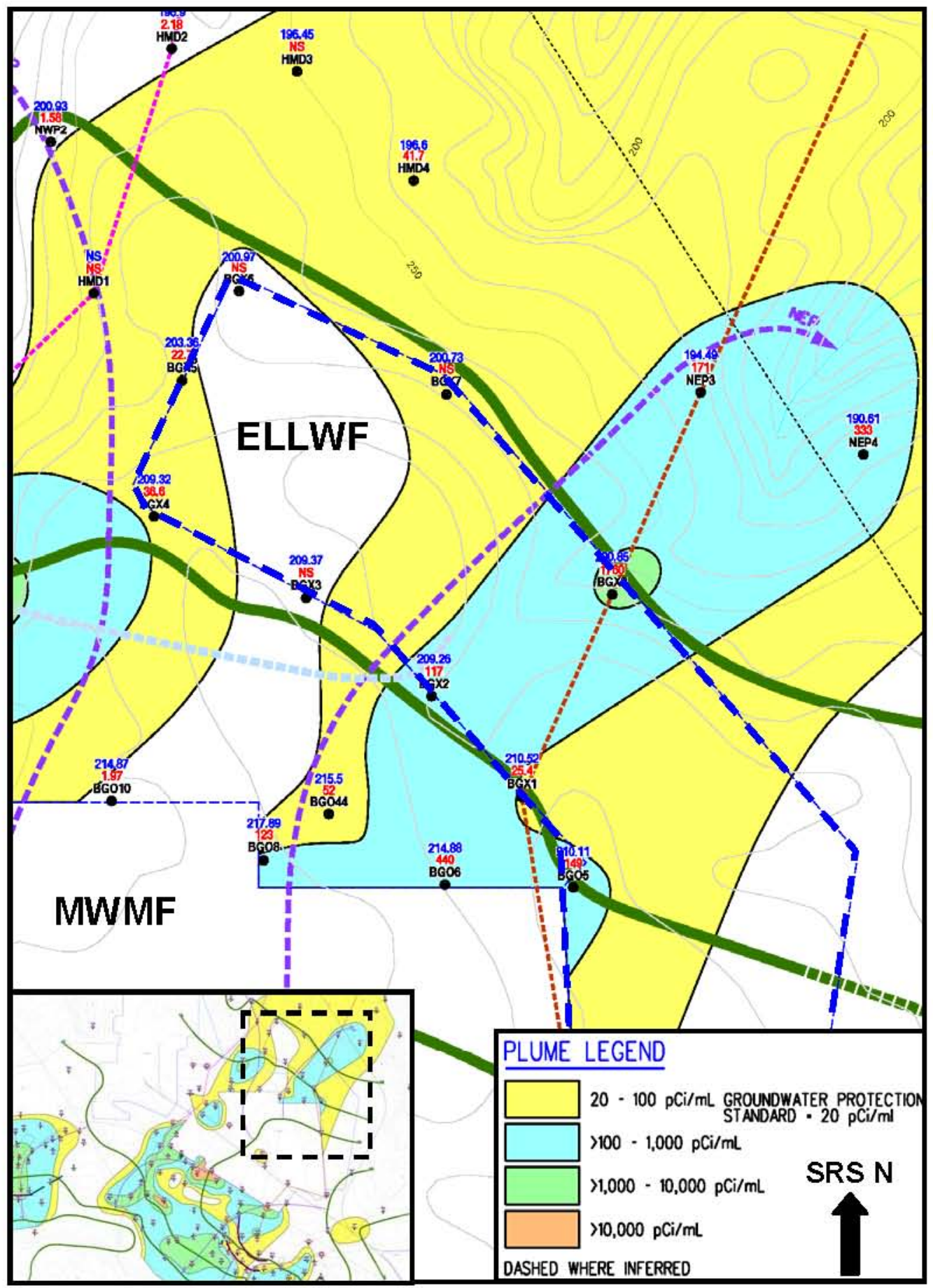

Figure 16. Tritium Plumes Moving from MWMF to ELLWF in Lower Aquifer Zone 
Table 9. BGO and BGX Monitoring Well Data Summary for FY2010

\begin{tabular}{|c|c|c|c|c|}
\hline Well Location & $\begin{array}{c}\text { Gross Alpha } \\
\text { (pCi/L) } \\
\text { (Action Level = } \\
756 \mathrm{pCi} / \mathrm{L}) \\
\end{array}$ & $\begin{array}{c}\text { Nonvolatile Beta } \\
(\mathrm{pCi} / \mathrm{L}) \\
(\text { Action Level }= \\
1600 \mathrm{pCi} / \mathrm{L})\end{array}$ & $\begin{array}{l}\text { Tritium }(\mathrm{pCi} / \mathrm{L}) \\
(\text { Action Level }= \\
7.57 \mathrm{E}+7 \mathrm{pCi} / \mathrm{L})\end{array}$ & $\begin{array}{c}\text { Exceeds } \\
\text { Action Levels? }\end{array}$ \\
\hline BGO1D & $\begin{array}{l}1.08 * \\
1.62 * *\end{array}$ & $\begin{array}{l}3.64 * \\
2.20 * *\end{array}$ & $\begin{array}{l}6.17 \mathrm{E}+03 \\
6.91 \mathrm{E}+03\end{array}$ & No \\
\hline $\mathrm{BGO} 2 \mathrm{D}$ & $\begin{array}{l}3.15 * * \\
2.28 * * \\
1.69 * *\end{array}$ & $\begin{array}{l}2.87 * \\
2.70 * * \\
2.60 * *\end{array}$ & $\begin{array}{l}5.09 \mathrm{E}+03 \\
4.70 \mathrm{E}+03 \\
4.88 \mathrm{E}+03 \\
4.93 \mathrm{E}+03 \\
\end{array}$ & No \\
\hline BGO3DR & $\begin{array}{l}3.59 * * \\
3.39 * *\end{array}$ & $\begin{array}{l}12.4 * * \\
3.37 *\end{array}$ & $\begin{array}{l}2.27 \mathrm{E}+05 \\
1.73 \mathrm{E}+05\end{array}$ & No \\
\hline BGO4D & $\begin{array}{c}1.54 * \\
0.89 * *\end{array}$ & $\begin{array}{l}4.31 * * \\
1.14 * *\end{array}$ & $\begin{array}{c}1.08 \mathrm{E}+06 \\
1.76+06 \\
1.73 \mathrm{E}+06 \\
\end{array}$ & No \\
\hline BGO5D & $\begin{array}{l}1.39 * \\
1.95 * *\end{array}$ & $\begin{array}{l}6.76 * * \\
1.35 *\end{array}$ & $\begin{array}{l}8.48 \mathrm{E}+06 \\
7.61 \mathrm{E}+06\end{array}$ & No \\
\hline BGX 1D & $1.49 *$ & $1.35 *$ & $\begin{array}{l}2.71 \mathrm{E}+06 \\
2.57 \mathrm{E}+06\end{array}$ & No \\
\hline BGX 2D & $1.13 *$ & $1.31 *$ & $1.17 \mathrm{E}+05$ & No \\
\hline BGX 5D & $4.34 * *$ & $7.27 * *$ & $2.14 \mathrm{E}+04$ & No \\
\hline BGX 8DR & $2.89 * *$ & $1.29 *$ & $\begin{array}{l}1.53 \mathrm{E}+06 \\
1.42 \mathrm{E}+06\end{array}$ & No \\
\hline
\end{tabular}

BGO Sampling: For BGO1D, BGO2D, BGO3DR, BGO4D and BGO5D, sampling conducted in January and July 2010.

BGX Sampling: For BGX1D and BGX8DR, sampling conducted in January and July 2010; for BGX2D and BGX5D, sampling conducted in July 2010; no data available for BGX3D, BGX4D, BGX6D, BGX7D, BGX9D, BGX10D or BGX12D.

Raw laboratory counting values are provided on the table; values with * are below the laboratory's quantitation limits (EPA "U" qualifier); values with ** are below the laboratory's quantitation limits but were able to be estimated (EPA "J" qualifier). For cases where data has been verified and validated, EPA qualifiers have been applied to the data (either "U" or "J").

Data are evaluated against action levels developed for the CA. These action levels are based on $25 \%$ of the projected peak groundwater concentrations for gross alpha, nonvolatile beta, and tritium beneath each facility as calculated in the CA. 


\subsubsection{Vault Integrity and Trench Cover Monitoring}

In addition to exposure pathways, certain facility features are relevant to monitoring release of constituents to the surrounding environment. Vault walls, roof, and floor are inspected every two years to monitor cell integrity per Procedure 724-EAV-50, “E-Area Vaults Subsidence and Low Activity Waste Vault Concrete Degradation Inspection (U)" (SWM, 2010c). The maintenance inspections required by this procedure for those relevant features were incorporated into the monitoring plan.

The most recent vault inspection was performed on February 26, 2009. This inspection requires general visual inspection of all exterior and accessible interior walls, looking for significant (obvious, substantial) cracking or degradation. The inspection results were satisfactory, and therefore, resulted in the determination that a formal, quantitative inspection was not required. Minor cracks in the vault walls were observed and noted. The notes are being maintained for future reference and trending.

Inspections of the soil cover over STs no longer receiving waste are conducted on a weekly time period (SWM, 2010e). A few sink holes and erosion areas were noted in these inspections. Solid Waste addressed each area of concern with grading equipment and soil fill material.

Inspections of the CIG cover are performed on a quarterly basis (SWM, 2010d). Four inspections were conducted in FY2010. In each inspection, no issues were found with the cover.

\subsection{RESEARCH AND DEVELOPMENT}

One new SA and one UDQE were completed in FY2010. Sixteen other PA-related tasks were completed in FY2010. Twelve PA maintenance activities were also completed. These tasks are described in Section 3.3.1. Tasks planned or underway in FY2011 are briefly discussed in Section 3.3.2.

\subsubsection{Past Events}

\subsubsection{Special Analyses}

Special Analysis of Two Waste Packages Exceeding WAC in Slit Trench Disposal Unit 4. SRNL completed a four-month long SA in May to support approval for returning one of the STs to operation. Operations at ST 4 had been halted due to inadvertent disposal of waste that did not meet the WAC for tritium. SWM discovered seven packages of LLW were incorrectly placed into ST 4 because of incorrect container labeling. Five of the waste packages were located in an area that had not yet been covered with soil and four of these packages were retrieved. The fifth package was determined to be within waste acceptance criteria and was not retrieved. The remaining two waste packages were in a section of the trench that had been covered with soil. SWM planning efforts to retrieve the remaining two waste packages had begun; however, the work promised to be much more hazardous and operationally challenging than the retrieval of the first four waste packages and would have resulted in the trench being out of operation for three to six months at a cost of \$1-2M. The modeling conclusively demonstrated the tritium inventory from these two waste packages is well within new tritium groundwater limits established in this SA. SRNL presented the results of the SA to the SWM Performance Assessment Review Committee (PARC) and received approval on May $12^{\text {th }}$. The Committee and DOE approved the SA and SWM returned ST 4 to operation on May $25^{\text {th }}$ at a significant reduction in cost and risk to personnel. (Collard et al, 2010)

\subsubsection{Unreviewed Disposal Question Evaluations}

Low-Activity Waste Vault Cell 11 Concrete Anchors Evaluation. During FY2010, SRNL prepared a report describing the evaluation of a proposed activity by SWM to install additional concrete anchors in the floor of the E-Area LAW Vault Cell 11 to support an extension of the temporary airlock enclosure.

Approximately 55 anchor bolts are expected to be installed in the Cell 11 concrete floor to secure the 
airlock extension walls. The proposed action is considered a change to the disposal facility from what has been previously described or analyzed in the most recent (2008) PA. Based on the SRNL evaluation, the proposed activity will not adversely affect operation of LAW Vault Cell 11 and is within the current PA conceptual envelope. SRNL presented the results of the evaluation to the SWM PARC on August 12. The PARC approved the proposed activity that can now proceed under the conditions specified by SRNL. (Jones and Phifer, 2010)

\subsubsection{Preliminary Studies}

Re-Assessment of the Condition of the SRS Bamboo Nursery. A re-assessment of the condition of the Bamboo Nursery that was established in 1991 was conducted during the summer of 2009. This effort was a follow-up to the last assessment in 2005 to determine the continued development of the bamboo stand, and its ability to delay the "invasion" of woody perennial species into areas occupied by dense bamboo stands. The bamboo has continued to fully occupy much of the nursery site and only a small number of new pine seedlings have become established in the four years since the last evaluation. The possible use of bamboo as a closure cap vegetation species was evaluated and possible future research and operational issues were identified within the report. (Nelson, 2009).

Neptunium IV and V Sorption to SRS Sediments. The objective of this study was to quantify the extent that neptunium (Np) sorbs to SRS sediments under varying groundwater conditions. Measurement of sorption under baseline conditions indicated that Np sorbed more strongly to SRS sandy sediments than originally expected. The presence of natural organic matter (NOM) resulted in an increase in Np sorption. This behavior is hypothesized to be the result of formation of a ternary Np-NOM-sediment complex. Slight increases in the $\mathrm{Np}$ sorption were observed when performing experiments in the presence of chemical reductants (dithionite, ascorbic acid, zero-valent iron) or under anaerobic conditions. Presumably, the increased sorption can be attributed to a slight reduction of $\mathrm{Np}(\mathrm{V})$ to $\mathrm{Np}(\mathrm{IV})$, the stronger sorbing form of $\mathrm{Np}$. The most significant result of this study is the finding that Np weakly sorbs to both sediments tested and that $\mathrm{Np}$ only has a slight tendency to reduce to its stronger sorbing form, even under the most strongly reducing conditions expected under natural SRS conditions. Based on these new measurements and the revelations about $\mathrm{Np}$ redox chemistry, new Np distribution coefficients, $\mathrm{K}_{\mathrm{d}}$ values, were recommended for use in future SRS performance assessment calculations. This will have an impact to the LLW-PA because 1) sandy sediment is the dominant sediment under the LLW facilities and 2) Np sorption is a key parameter governing risk. (Kaplan, 2009a)

Conditions Impacting Corrosion of Discarded ETP Carbon Vessels. Spent carbon from the Effluent Treatment Project has been dispositioned in stainless steel vessels in the STs of Savannah River Site's ELLWF. A previous structural integrity evaluation was performed under the assumption that corrosion occurred only on the external surfaces of the vessels. A new evaluation is being performed by SRNL under the assumption that both external and internal corrosion may impact the long-term structural integrity of the vessels. In support of this evaluation, a literature review and an analysis of the applicable data were completed to identify the conditions driving exterior and interior corrosion of the vessels. Specifically, the exterior conditions that were addressed included: a) the backfill soil type; b) the resistivity; and c) the $\mathrm{pH}$. The interior conditions that were addressed included: a) the distribution of solid, liquid, and gaseous phases in the vessels; $b$ ) the chemical composition of the liquid; c) the resistivity of the liquid; d) the $\mathrm{pH}$ of the liquid; and e) the gases in the headspace. Changes in the interior conditions due to the influence of microbial activity over time were also addressed. (Reboul and Brigmon, 2009).

ETP Carbon Vessel Post Burial Assessment. A calculation was made to estimate time-to-failure for ETP carbon vessels buried in E-Area STs and subjected to corrosion degradation over a 130-year control period and beyond. Based on the use of bounding soil conditions, and the estimated upper and lower bounding corrosion rates $(0.001 \mathrm{in} / \mathrm{yr}$ upper bound based on pitting and $0.00004 \mathrm{in} / \mathrm{yr}$ lower bound based on general corrosion, doubled to account for inside and outside of the vessel), ETP carbon vessels will not collapse due to dynamic compaction of the entire overlaying soil column, and addition of a final soil cap prior to final closure. Based on the corrosion rates utilized, the vessels will become hydraulically active 133 years after burial. (Estochen, 2010a) 
SRNS-STI-2011-00024, Revision 0

Rapid Response Evaluation of Onsite Disposal Options for HWCTR. Site Deactivation and Decommissioning (SDD) is planning an American Recovery and Reinvestment Act (ARRA) project to dismantle and remove the deactivated and de-inventoried HWCTR for disposal under CERCLA later this year. Back in January 2010, SW Engineering and Regulatory Integration requested that SRNL to perform a rapid response analysis of HWCTR to support a key decision to either proceed with design/planning for off-site disposal or pursue onsite disposal in E-Area. SRNL developed one and two-dimensional models of a proposed ST disposal configuration of HWCTR and performed vadose zone modeling simulations using these two models to obtain contaminant flux to the water table ( $\mathrm{pCi} / \mathrm{yr}$ per $\mathrm{Ci}$ disposed) and compared peaks from key risk-driving radionuclides with baseline PA results. SRNL evaluated three key enhancements: 1) taking advantage of corrosion-controlled release of activation products from HWCTR's stainless steel heat shield, 2) employing the latest site-specific radionuclide sorption coefficients, or $\mathrm{K}_{\mathrm{d}}$ 's, for the key risk-driving radionuclides, and 3) including grout for solubility control and structural stability. These enhancements reduced the peak flux values for the radionuclides of interest by several orders of magnitude leading to the preliminary conclusion of an acceptable level of impact on concentrations at the 100-m well, the point of assessment (POA) for DOE PAs. As a result of this preliminary evaluation, the customer decided to proceed with onsite disposal thus saving the significant cost of off-site disposal and helping to ensure that the D\&D of HWCTR could be completed within the time frame of ARRA funding. DOE subsequently issued an Action Memorandum for the Removal Site Evaluation Report/Engineering Evaluation/Cost Analysis (RSER/EE/CA) for HWCTR selecting Alternative 3, In Situ Decommissioning with Reactor Vessel and Steam Generator Removal. Under this alternative, the reactor vessel and steam generators would be removed and disposed at an appropriate disposal facility.

Radionuclide Characterization of HWCTR Reactor Vessel. SWE and Regulatory Integration and Environmental Services (RI\&ES) requested that SRNL develop a defensible estimate of radionuclide inventory associated with various HWCTR components to determine if onsite disposal in E Area was an option. Activation and fission products in the various components of the HWCTR reactor vessel were quantified using Monte Carlo N-Particle Transport and ORIGEN-S modeling. The characterized components include: a) activated thermal shields, b) activated reactor-vessel liner walls and c) retained contamination from failed irradiated fuel assemblies. The total radionuclide inventories associated with HWCTR were computed by summing the contributions of the various components. Results of the characterization were issued to SDD in the form of an E7 Engineering Calculation, Q-CLC-A-00033, as requested by SDD. From this calculation, SWM Engineering determined that HWCTR disposal would exceed numerous limits for the E-Area Slit Trenches and LAW Vault, the only two E-Area disposal units permitted to receive CERCLA waste under CERCLA offsite rule authority granted by the EPA. (The IL Vault is also approved for CERCLA waste, but was not considered because the weight of the reactor prevents crane use near the IL Vault. (Vinson et al, 2010)

Radionuclide Characterization of the HWCTR Steam Generators. Radionuclide characterization of the steam generators for HWCTR was performed to support disposition of the generators. Three sources of radionuclide contamination were identified and quantified: 1) corrosion of activated thermal shields in HWCTR, 2) corrosion of the activated vessel liner in HWCTR and 3) irradiated uranium released from the failed fuel assemblies of HWCTR. Results of the characterization indicate that the total radionuclide inventory associated with the steam generators is within the WAC limits for ST disposal. An E7 calculation, Q-CLC-A-00034, quantifying the distribution of radionuclides in the steam generators has been issued. (Reboul and Vinson, 2010)

Heavy Water Components Test Reactor Supporting Structural Calculation. SRNL completed calculations documenting the corrosion response and structural behavior of the HWCTR vessel over time in an E-Area ST disposal environment (M-CLC-E-00048). This evaluation predicted that following disposal, the reactor vessel will become hydraulically active in 28 years and structurally unstable after 886 years. These results were used as input to the HWCTR SA model. (Estochen, 2010b)

Slit Trench Infiltration Estimates and Waste Zone Properties. Two reports that discuss infiltration projections and a revised waste zone representation have been produced to support future special analyses. The first report provides Slit Trench closure cap infiltration estimates for both the intact and subsided condition for ten and fourteen-foot trench spacings. A second document provides a revised hybrid Slit 
SRNS-STI-2011-00024, Revision 0

Trench waste representation that combines bulk waste and containerized waste representations in a manner that conserves mass so that radionuclide retardation is not unduly conservative or non-conservative. The hybrid Slit Trench waste properties were determined based upon the estimate that over the past 15 years approximately $67 \%$ of all waste disposed was considered bulk waste and $33 \%$ of the waste was considered containerized waste. (Phifer, 2010a and 2010b)

Geochemical Data Package for Performance Assessment Calculations Related to the Savannah River Site. SRS disposes of low-activity radioactive waste within subsurface-engineered facilities. One of the tools used to establish the capacity of a given site to safely store radioactive waste is the PA. The objective of this document is to provide the geochemical values for the DOE 435.1 PA calculations. This work is being conducted as part of the on-going maintenance program that permits the PA to periodically update existing calculations when new data becomes available and builds upon earlier PA geochemical data compilations. (Kaplan, 2009b)

Closure Cap Drainage Layer Hydraulic Conductivity Over Time: Literature Search. The drainage layer within a closure cap is one of the fundamental parameters controlling closure cap performance. SRNL issued results of a literature search to identify references related to closure cap drainage layer long-term hydraulic performance. The search focused on closure-cap drainage layer studies as well as colloid transport and deposition within vadose sands, a potential mechanism for drainage layer plugging. The information will serve as the basis for a laboratory and field testing program plan for quantifying long-term drainage layer performance. (Jones, 2010)

Iodine Geochemistry in the SRS Subsurface and Wetland Sediments. This report provides a summary of work performed in FY2010 by SRNL and the Savannah River Ecology Laboratory (SREL) for SWM and the Office of Science related to radioiodine in the SRS subsurface environment and also provides a discussion of the implications for Solid Waste disposal. For the first time, $\mathrm{K}_{\mathrm{d}} \mathrm{S}$ are reported as a function of iodine speciation. Speciation of radioiodine in SRS soils showed that the more strongly sorbing species of iodine, namely iodate, was present. SREL contributed an important data set showing that iodate, sorbs much more strongly to our sediments than iodide, the presumed species. SRNL has developed in-house capabilities to measure iodide and iodate at environmental concentration levels. SRNL is now one of the few labs in the nation that has this analytical capability, which will help us to justify increasing radioiodine $\mathrm{K}_{\mathrm{d}} \mathrm{S}$ that are used in SRS Performance Assessments and Composite Analyses. (Kaplan et al, 2010)

Summary Report for the VL-26 Lysimeter Field Characterization at Slit Trench 1. SRNL issued results and recommendations to Solid Waste for the VL-26 lysimeter field characterization, which was conducted on the southwestern side of ST 1 at the ELLWF. Tritium analyses from the Spring and Fall 2009 sampling events showed that the deepest lysimeter at the VL-26 cluster exceeded its specified action level for tritium. As part of the VL-26 characterization, SRNL conducted a field investigation that entailed rotosonic drilling to collect core and groundwater for laboratory analysis. The soil and water analyses indicate that the tritium emanating from ST 1 near VL-26 is fairly localized and has had no discernable effect on groundwater near the ST. A discussion of the results of the field investigation is provided in Section 3.2.1.5 of this Annual Review report. (Millings and Bagwell, 2010; Millings et al, 2010)

Lysimeter Demolitions and Modification at Slit Trenches. To accommodate the installation of a stormwater cover, SRNL reviewed the sampling histories and tritium data for the 13 lysimeter stations at ST 5 in E-Area, and recommended simplifying the lysimeter network by demolishing all but the most critical or best performing lysimeters. During May 2010, SRNL provided technical guidance and field oversight for a subcontract task to demolish unneeded lysimeter stations and to retrofit remaining stations to accommodate the stormwater runoff cover. During this assessment period, SRNL produced a memorandum report of these. Also, during this period SRNL completed similar modifications to lysimeter stations at Slit Trenches 1-4 which will be documented in a second report. (Bagwell, 2010)

E-Area Concrete and Grout Durability Simulations by SIMCO Technologies. SRNL prepared a report summarizing simulation results generated by SIMCO Technologies, Inc. using their STADIUM ${ }^{\circledR}$ code for leaching of surrogate E-Area cementitious barriers exposed to solutions with $\mathrm{pHs}$ between 12.4 and 7. The $\mathrm{pH} 7$ solution is utilized as a surrogate for SRS groundwater / vadose zone water because the vaults are in 
SRNS-STI-2011-00024, Revision 0

the vadose zone. The higher $\mathrm{pH}$ leachates are surrogates for leachates generated as the result of vadose zone water contacting concrete that has been decalcified to varying degrees from infiltrating water. Calcium leaching is the primary aging / degradation mechanism identified for the E-Area concrete vaults and component-in-grout barriers. The depth of alteration of the E-Area cementitious barriers due to calcium leaching over long times up to 10,000 years is predicted. Because STADIUM $^{\circledR}$ input data from the actual E-Area cementitious barriers were not available, SIMCO Technologies, Inc. used data for comparable materials from their current database. Results from the simulations will be employed to better represent concrete vault degradation in future PA modeling of the E-Area vaults. (Langton, 2009)

Proof-of-Concept Modeling of Cracked Porous Medium. SRNL contracted with Clemson University to develop modeling of a cracked porous medium's affect on waste transport. Because fracture permeability is generally much greater than cementitious matrix permeability, fracture networks have the potential for being highly effective pathways for conducting fluid containing contaminant species. Clemson developed a model that explicitly calculates a flow field in the cracks and flow field in the porous medium with the cracks being randomly generated in both length and orientation. Various patterns of fractures were simulated and compared. Results show that the density of the fracture network has a profound affect on the flow and mass transfer of the medium. An effective $\mathrm{K}_{\mathrm{d}}$ calculation for lumping an entire crack network into an equivalent single-fracture system was proposed for further investigation in a final research progress report submitted in August. (Dong et al, 2010)

\subsubsection{PA Maintenance}

FY2009 Annual Review of the E-Area Performance Assessment and Composite Analysis sent to DOE. The Annual Review of the ELLWF PA and site Composite Analysis for FY2009 was prepared and forwarded to the DOE. The objectives of the Annual Review were to:

- Assess LLW disposal operations for the prior year versus the PA baseline.

- Evaluate the adequacy of the approved PA baseline and associated controls.

- Determine if all LLW disposal operations at SRS are within the bounds of the currently applicable CA.

The Annual Review concluded that LLW operations in E Area conducted in FY2009 were well within the performance envelope analyzed in the E-Area PA and associated SAs. The report also demonstrated that operations in the ELLWF and the SDF were within the bounds of the currently applicable CA. (Swingle et al, 2010)

2010 ELLWF PA and SRS CA Maintenance Plan Transmitted to Department of Energy Savannah River (DOE-SR). SRNL, RI\&ES and SWM prepared the FY2010 update to the ELLWF PA and SRS CA Maintenance Plan. Because the Performance Assessment and Composite Analysis results are in part based on technically uncertain data, conservative parameters or both, a maintenance program is needed to continue to reduce uncertainty in the inputs and assumptions providing greater confidence in the results of the analyses and in the long-term plans for public and environmental protection. Additionally, a disciplined process to address potential changes in disposal operations (e.g., new waste forms, change in unit design) is needed to ensure that proposed changes do not adversely affect disposal facility performance. The preparation and execution of this plan is consistent with the "Maintenance Guide for DOE LLW Disposal Facility PA and CAs" (November 10, 1999) as reflected in DOE Order 435.1. The purpose of both the PA and CA maintenance programs is to confirm the continued adequacy of the PA and CA and to increase confidence in their results. The maintenance plan reflects both PA and CA-related activities in the current fiscal year and the outyears for ten-year budget planning purposes. This plan is prepared and updated each year and submitted to DOE.

Separate maintenance programs have been established for the SRNS SWM PA (i.e., for the ELLWF) and the Savannah River Remediation (SRR) Liquid Waste Organization PA's (i.e., for the SDF and Tank Closures). The scope of this update to the maintenance plan is limited to the ELLWF PA and the SRS CA. SRNS and SRR have completed a consistency review between the maintenance program described in this plan and the SRR maintenance plan under the auspices of the DOE Order 435.1 Working Group. This 
review has ensured that the scope in both programs is consistent, avoids duplication of effort, and benefits from sharing of data. (SRNS, 2010a)

Update of ELLWF Disposal Limits Database on ShRINE. A revision to the E-Area Low-Level Waste Facility Disposal Limits Database has been developed and is accessible from the Solid Waste Management homepage on ShRINE. This latest revision incorporates Special Analysis of Tritium Disposal Limits for EArea Slit Trench 4 (Collard et al, 2010). The database provides a single up-to-date location containing all of the currently valid ELLWF disposal unit inventory limits. This database will continue to be updated as revisions to the ELLWF inventory limits are made. (Swingle, 2010a)

Workshop and Training for PORFLOW. A workshop on the PORFLOW computer code, lead by Dr. Akshai Runchal of ACRi, USA, was held from December 7 - 11. The PORFLOW code is one of the primary codes used for groundwater flow and contaminant transport modeling for PA work at the SRS. There are currently a limited number of experienced PORFLOW users on site but an increasing need for PORFLOW modeling. The workshop included beginners' training for new and inexperienced PORFLOW users, as well as training on new PORFLOW features for more advanced users and discussions on desired further updates and solutions to technical issues. Use of recent and proposed improvements will allow site modelers to produce better models more efficiently.

Acceptance of GoldSim 9.60 SP4 for use in Performance Assessment and Composite Analysis. GoldSim ${ }^{\mathrm{TM}}$ is software purchased from the GoldSim Technology Group LLC to assist in the development of Performance Assessments and Composite Analyses for SRS radioactive disposal facilities. GoldSim is specifically useful for uncertainty analyses because of its Monte Carlo functionality. Under the SRS Quality Assurance (QA) Program, a software QA plan is required for most software used at the site. Under the Software QA Plan for the GoldSim ${ }^{\mathrm{TM}}$ code, acceptance testing is required for each version of GoldSim $^{\mathrm{TM}}$ used at the SRS. Acceptance Testing was performed under the site load personal computer operating system (Windows ${ }^{\mathrm{TM}} \mathrm{XP}$ ) that verified that the code functioned appropriately and produced the results anticipated by the vendor. A memo was written documenting the successful completion of the testing and the acceptance for use of GoldSim ${ }^{\text {TM }} 9.60$ Service Pack 4 at the SRS. (Swingle, 2010b)

GoldSim Model Workshop. A workshop for the GoldSim ${ }^{\mathrm{TM}}$ code was offered at SRS on January 11-14. GoldSim $^{\mathrm{TM}}$ is a highly graphical programming language that is used at SRS for Performance Assessment modeling. As the site gets more involved in probabilistic modeling, the use of GoldSim ${ }^{\mathrm{TM}}$ is increasing. The workshop included an introductory level presentation of GoldSim ${ }^{\mathrm{TM}}$ with numerous hands-on computer-based exercises that featured various capabilities of the most recent version of the code.

Uncertainty and Sensitivity Workshop. A workshop on Uncertainty and Sensitivity Analysis Techniques was held February 8-10 which addressed issues related to developing appropriate probability density functions (PDF's) for probablistic modeling. Dr. Srikanta Mishra of Intera, Inc. was the primary instructor, while Dr. Matt Kozak, also of Intera, Inc. provided part of the presentations.

Software Testing and Verification of PORFLOW 6.21.0. This Software Testing and Verification report documents the comparison of the 64-bit PORFLOW version 6.21.0 to the 64-bit PORFLOW version 6.10.3 and the 64-bit PORFLOW version 6.10.3 to the 32-bit PORFLOW version 6.10.3 on the Linux operating system. None of the results differ between 64-bit PORFLOW version 6.10.3 and 32-bit PORFLOW version 6.10.3. PORFLOW version 6.21.0 has fixed several bugs, bringing its solutions in-line with analytical results. The QA tests confirm that while there are a few problems remaining, PORFLOW version 6.21 .0 on the Linux platform meets the needs of the tank and vault closure applications.

(Whiteside, 2010)

Neptune and Company GoldSim Products Delivered. A number of secondary issues raised in the DOE-HQ review of the 2008 ELLWF PA were assigned to PA maintenance. As part of that commitment, Neptune and Company was subcontracted to make improvements to the probabilistic sensitivity and uncertainty analysis of PA results. Neptune completed the initial phase of this work delivering updated GoldSim ${ }^{\mathrm{TM}}$ models for the ELLWF STs, ETs and CIG Trenches (Tauxe and Catlett, 2010). SRNL, which consulted 
with Neptune on the development of the models, is reviewing and preparing the models to be used for benchmarking with ELLWF Performance Assessment PORFLOW modeling results.

Neptune also transmitted a draft report for SRNL review documenting development of new geochemical distributions for SRS probabilistic modeling efforts (Fitzgerald, 2010). This revision includes $\mathrm{K}_{\mathrm{d}}$ distributions for elements U, Pu, Sr, Ra, and Tc in "SandySoil" and "ClayeySoil" representing the subsurface conditions found in E-Area.

SRNL Implements Modeling Improvements that Increase Efficiency for Performance Assessment Work. SRNL has implemented two modeling improvements that have resulted in a significant increase in efficiency. In addition, the number of PORFLOW licenses was increased from 13 to 25 , which reduced the time required to execute a set of PORFLOW runs by about one half. SRNL procured sufficient hardware resources (i.e., rack-mounted processor Linux machines) to ensure the efficient use of the additional PORFLOW licenses. Taken together these actions have resulted in about a four-fold decrease in the amount of time required to accomplish a given modeling task.

Acceptance Testing for PORFLOW Version 6.30.1. SRNL prepared a memorandum presenting the results of Acceptance Testing for PORFLOW version 6.30.1 with respect to implementation of the enhanced hydrodynamic dispersion model and two additional software upgrades: 1) an increase in the allowable number of STATistics files to 224 and 2) an increase in the computational node limit to 1,024,000. PORFLOW version 6.30.1 passed all three acceptance tests. (Aleman and Flach, 2010)

\subsubsection{Future Events}

The Future Events section describes PA/CA work planned for FY2011. Much of this work is identified in the 2010 update to the PA/CA Maintenance Plan (SRNS, 2010a). Starting and/or completing these tasks in the upcoming year are subject to customer priorities and available funding and resources.

\subsubsection{Special Analyses}

Special Analysis of Slit Trench Disposal of the Heavy Water Components Test Reactor (HWCTR). This special analysis supports a key site objective to complete decommissioning of HWCTR under the Recovery Act modification to the Prime Contract for accelerating completion of Environmental Management closure activities at SRS. DOE issued an Action Memorandum for the Removal Site Evaluation Report/Engineering Evaluation/Cost Analysis (RSER/EE/CA) for HWCTR selecting alternative 3, In Situ Decommissioning with Reactor Vessel and Steam Generator Removal in 2010. Under this alternative, the reactor vessel and steam generators would be removed and disposed at an appropriate disposal facility. Site D\&D is planning to dismantle and remove the deactivated and de-inventoried Heavy Water Components Test Reactor for disposal in E-Area under CERCLA in January 2011.SRNL started the special analysis in FY10 with a rapid response evaluation of onsite disposal options for HWCTR. This work is being followed up by a full special analysis which will be completed and approved in early FY11.

Re-evaluate Operational Covers Over Center Slit Trench Group. In FY08, DOE entered into an agreement with the United Stated Environmental Protection Agency and the South Carolina Department of Health and Environmental Control (SCDHEC) to place covers over STs to enable continued disposal of CERCLA solid waste. Because the covers change the trench operating conditions and closure design, DOE Order 435.1 required that an SA be performed to assess the impact. In FY09, SRNL completed a SA to determine the effects of placing operational stormwater runoff covers over STs 1 through 7. To simplify the analysis, SRNL modeled three cases; installing covers over all STs simultaneously at year 5, 10 and 15 of the 30year operational period. Limits were developed by taking the minimum of the three cases evaluated. In FY10, SRNL is reanalyzing the center STs because ARRA plans have changed the timing for placement of the stormwater runoff covers. The new cover placement dates are outside the bounds of the previous analyses. The new more detailed SA will also improve upon the previous analyses by more explicitly considering the timing and the location of disposals in segments of the STs. The previous analysis assumed that the waste was disposed of all at one time and that the concentration of the waste was uniformly 
SRNS-STI-2011-00024, Revision 0

distributed throughout each set of five STs. This work was started in FY2010 and is expected to finish in FY2011.

Develop Three-Dimensional Vadose Zone Model of Center Slit Trench Group. PA modeling of E-Area disposal trenches (STs, ETs and CIG trenches) has become necessarily more complex as disposal units are filled, operational changes are made, and characterization of the hydrogeology and geochemistry of the disposal system is improved. Because trenches offer little in the way of engineered barriers to retard radionuclide migration during the operational period (exceptions being CIG grout envelope and now, operational covers) it is important to develop realistic conceptual models in line with the available data to better understand contaminant release from the waste zone and migration to the water table. Vadose zone modeling has become an important tool in investigating the source of tritium releases as detected in lysimeters surrounding the trenches. In PA work to date, all E-Area trench disposal units and the surrounding vadose zone down to the water table were able to be represented by two-dimensional vadose zone models because of the layout of long trenches with uniform cross-sections and the fact that very little of the trench real estate had been used. However, two-dimensional modeling is of limited help when trying to represent three-dimensional vadose zone contaminant plumes. Three dimensional vadose zone modeling will be employed to provide a better match with vadose zone well tritium concentrations and trench source terms. In addition, as Solid Waste expands into the remainder of E Area, future trench layouts will move away from the standard trench footprint to trenches with non-uniform cross-sections that take advantage of the surrounding topography. All of these complexities could more accurately and readily be modeled using a three-dimensional representation in the vadose zone.

\subsubsection{UDQEs}

Maintain PA Controls System through UDQEs. UDQ Evaluations will continue to be required throughout the life of the facility. The 2008 PA was implemented and incorporated into the RWMB for E-Area in October 2008. All UDQEs going forward until the next PA update will be evaluated against the 2008 PA.

Tall Box Disposal Evaluation. SWM plans to dispose of additional tall boxes (greater than 16 feet in height) in E-Area Slit Trenches. Several tall boxes ranging from 20-26 feet high stored in the Used Equipment Storage Area which will be disposed in STs in the upcoming months. Some of these tall boxes contain equipment with lead shielding or counterweights which will require grout encapsulation to meet the SC DHEC requirements for lead encasement. In most cases this involves pouring grout around the perimeter of the boxes in a trench rather than inside the boxes because of contamination control concerns with opening the boxes. Neither can these boxes be laid on their sides during disposal due to safety and contamination control concerns. The proposed location for these boxes is the southern end of Slit Trenches 8,9 and 10 due to the greater depth to water table in this area.

\subsubsection{Preliminary Studies}

Evaluate Available Groundwater Codes for Potential Use in Future PA's and CA's. SRNL plans to evaluate advances in available groundwater codes for potential use in future PAs and CAs. It is prudent to ensure the program remains on the cutting edge of code development for this important program. SRNL will pursue a multi-year program to: 1) conduct a relatively quick paper study to survey and screen available open/closed source and proprietary/free groundwater codes that we should consider for use in future PA efforts, 2) perform a head-to-head comparison of the remaining codes leading to selection of at least one as a second PA-level code, 3) upgrade the selected code to perform PA-critical functions, solve problems representative of SRS groundwater flow and transport conditions, and add unique features/commands found in PORFLOW, and 4) develop software QA and document Testing and Verification.

Evaluate Impact of Numerical Dispersion for PORFLOW in Two and Three Dimensions. Numerical dispersion is an artifact of all numerical modeling. It arises from trying to reduce numerical oscillations resulting from solving contaminant transport equations. This effect appears as an overshoot and undershoot near the concentration front, thus 'smearing' contamination across the interface between adjacent cells. SRNL has generally configured the PA models to not simulate physical dispersion (a real phenomenon) in 
an attempt to compensate for the expected numerical dispersion. However, numerical dispersion in the PA models needs to be investigated to determine the extent of this phenomenon and to take appropriate compensatory measures, if they are needed. The impact of numerical and physical dispersion in PORFLOW on peak solute concentrations was examined in the PORFLOW testing and verification for a one-dimensional saturated soil column. This study showed that fine mesh resolution is needed to capture the peak solute concentration in PORFLOW if no mechanical dispersion is present. SRNL plans to address numerical dispersion in two and three dimensions in this study.

Investigate PORFLOW Improvements and Auxiliary Programs to Help Automate Data Manipulation and Reduce Potential Errors. A number of improvements could be made to PORFLOW that would reduce the need to create programs to handle intermediate data steps. These steps introduce potential for errors and increase the amount of time and manpower required to perform analyses. A workshop with the proprietary owner of the PORFLOW code took place in FY2010 to present new developments in PORFLOW and discuss further improvements to the code. A follow-up onsite consulting visit is planned this year with the PORFLOW owner to resolve numerical convergence difficulties experienced by SRS modelers. Also in FY11, SRNL will prepare a software QA plan for the in-house FORTRAN code that automates the calculation of doses and pathway limits using PORFLOW output.

Clarify Understanding of Sorption Behavior for Key PA Radionuclides. SRNL will perform laboratory experiments to develop additional site-specific $\mathrm{K}_{\mathrm{d}}$ values. The radionuclides of interest for characterization will be determined based on results and limits developed during preparation of the PA revision. In FY2010 SRNL started the following sorption studies: 1) quantifying sorption of radioiodine $\left(\mathrm{I}^{-}\right.$and $\left.\mathrm{IO}_{3}{ }^{-}\right)$to wetland sediments and comparing to subsurface sediments, and 2) quantifying sorption of radium (Ra), strontium (Sr) and neptunium (Np) to subsurface sediments. Sorption studies for Ra, $\mathrm{Sr}$ and $\mathrm{Np}$ will be completed in FY2011. In addition, laboratory column experiments will be conducted with iodide, iodate, and organoiodine, all species that naturally occur in SRS groundwater, to study flow characteristics and to measure, amongst other parameters, Kd values.

Incorporate Reactive Transport Modeling into PA. Although $\mathrm{K}_{\mathrm{d}}$ values are convenient for inclusion in transport models, they may not always capture a full picture of the true geochemistry believed to be occurring in a chemically dynamic system. For those systems where a simple $\mathrm{K}_{\mathrm{d}}$ concept does not adequately capture sorption behavior (e.g., cellulose degradation products [CDP] or in cementitious systems), it is necessary to rely on site-specific and condition-specific experiments to provide insight into how the radionuclides interact with the solid phase. Examples of chemical reactions that complicate sorption behavior include; oxidation-reduction, solubility and gas-liquid phase portioning. For radionuclides controlled by these phenomena, it is in the interest of the PA to incorporate more processdriven (mechanistic) approaches to describing the geochemistry in the PA. In FY2010 and 11, specific work will be directed at evaluating the effect of elevated $\mathrm{pH}$ values, i.e., background $\mathrm{pH} 5.5$ to 12 , on sorption.

Evaluate Importance of Colloids as Contaminant Transport Vector. Facilitated transport via colloids is currently represented in a rather elementary fashion in the PA ST and ET model for plutonium isotopes. This study will assess colloid stability and mobility for our disposal environment and determine the importance of colloids as a contaminant transport vector. Recommendations will be made whether this phenomenon should be accounted for, and if so, how it should be treated in the PA modeling. The laboratory studies for this item started in FY2009, continued in FY2010 and are expected to complete in FY2011.

Measure Physical Properties of E-Area (LAW and IL) Vault Concrete. In FY2009 SRNL cored the concrete test panel located in E-Area. The E-Area test panel is made from the same concrete formulation and was placed and cured in the same manner as the LAW and IL Vaults. Samples from this coring were sent to an offsite geotechnical testing laboratory for determining hydraulic properties (i.e., saturated hydraulic conductivity, water retention curves, porosity, dry bulk density, and particle density of the concrete). Saturated hydraulic conductivity or permeability was measured using a flexible wall permeameter following the ASTM D5084 test method. This technique was developed primarily for soils but has also been used for measuring concrete permeability. The method has a practical limit of $1 \mathrm{E}-10$ 
SRNS-STI-2011-00024, Revision 0

$\mathrm{cm} / \mathrm{sec}$ for permeability measurements as it relies on gradients of 30 or less and on volumetric measurements of permeating water. Test method modifications are possible that increase the sensitivity of the measurement. However, because of this limitation SRNL is pursuing additional measurements using a fundamentally different approach, based on a drying test. This test method relies on gravimetric measurements of moisture loss under transient conditions rather than volumetric measurements. Relying on gravimetric measurements provides a more sensitive measurement of hydraulic conductivity. In FY2010 additional concrete core were obtained from the test wall and submitted to a different offsite testing laboratory specializing in measuring and modeling hydraulic properties of low-permeability cementitious materials. In 2011, testing will be completed and a final test report prepared.

Assess Data from B-25 Box Corrosion Monitoring Field Study. In FY2002 SRNL destructively examined a weathered B-25 waste disposal box for corrosion. The box had been buried in an E-Area test pit for approximately eight years. Using this data the material condition and integrity of B-25 boxes buried in EArea can be estimated over longer periods of time. However, the measured corrosion rate can increase with time, remain constant, or decrease with time depending on the specific conditions of the disposal environment. Because the data utilized to predict the future corrosion represents only one data point obtained at eight years post-burial, it is not known which corrosion rate model is more appropriate. The objective of this activity is to determine the long-term B-25/B-12/Sealand container material corrosion rate and how that rate changes with time in an Engineered Trench environment. This information is necessary in order to select the optimum time for performing dynamic compaction and to minimize the cost of cap maintenance during the institutional control period. In FY2005, SRNL completed field deployment of metal coupons and instrumentation in a designated unused area near ET2. Baseline measurements were collected and a field completion report prepared in FY2006. SRNL has been following up with quarterly resistivity measurements ever since. Significant changes in resistance will be used as an indication of when coupons should be excavated and a corrosion evaluation performed. A data report will be produced in those years. Data needs to be collected for approximately 15 years to support long term corrosion projections.

Evaluate Storm Water Cover Runoff, Durability, and Maintenance. Storm water runoff covers will be installed over trench disposal units as they are filled and no longer accepting waste during the operational period to promote runoff at a low installation and maintenance cost. This patchwork of covers will be expanded into an integrated storm water runoff cover system at the end of operations and beginning of the Institutional Control period of the ELLWF. Operational storm water runoff covers were installed over filled CIG Trench segments starting in FY2006. A different geomembrane was selected for installation over STs 1-5 in FY2011. A test area for the CIG trench geomembrane was constructed in FY2006. A similar test area will be constructed when the first ST covers are installed in FY2011. SRNL has been investigating various methods to directly and indirectly interrogate the durability and performance characteristics of the planned ST covers using the planned ST covers test area as a basis for a long-term cover system monitoring and maintenance program. In early FY11 SRNL reviewed a test matrix of these methods with SWM Engineering and RI\&ES for input and selection, and a test plan was prepared for implementing the recommended methods. Installation of the field test site is scheduled for 2011.

Geochemistry Lysimeter Field Study. Great progress has been made in parameterizing the geochemical data package based on short term laboratory data derived from week- to month-long contact experiments. The next level of higher quality data would be those derived from field lysimeter experiments, the subject of this task. The objective of these lysimeters is to generate sorption data and, more importantly, a longterm conceptual geochemical model of the radionuclides. Some issues that may be addressed are mobile colloids, microbial processes, long-term transport interactions that cannot be measured in short-term experiments, plant uptake, and longevity of reducing grout conditions. Radionuclides of interest include plutonium, technetium, strontium, cesium, europium (for all trivalent cations, e.g., Am and $\mathrm{Cm}$ ), radium, neptunium, and iodine. In FY11 various forms of buried sources of radionuclides will be placed in a series of 19-L columns (approx. $2.5 \mathrm{ft}$ high by $0.3 \mathrm{ft}$ dia.) packed with SRS vadose zone sediment and exposed to rainfall. The rainfall will infiltrate through the lysimeters and be collected in large collection reservoirs that will permit routine sampling and analysis. After a set period of years (e.g., two, four, and ten years) various lysimeters will be terminated and a sediment core will be collected from the center of each lysimeter. From the leachate aqueous samples and the sediment core data, the extent of radionuclide 
migration will be determined. $\mathrm{K}_{\mathrm{d}}$ data and solubility data will be generated. Maps of the extent that the radionuclides moved in the soil will be made.

\subsubsection{PA Maintenance}

Refine and Further Develop GoldSim Models. Initial GoldSim models of specific E-Area disposal units (i.e., ST, ET, CIG trenches, and NRCDAs) were developed as part of the PA revision and presented to the Low-Level Waste Disposal Facility Federal Review Group (LFRG) Review Team. The Review Team acknowledged this to be a good start on evaluating uncertainty in the disposal system, but indicated that further work was needed. In FY2010, SRNL, working with an experienced GoldSim modeling subcontractor, completed initial improvements to GoldSim models for the Slit \& Engineered trenches and CIG trenches to increase confidence in the robustness of the radionuclide disposal limits for these facilities. In FY11 SRNL will complete benchmarking of GoldSim trench models with PORFLOW results and summarize these initial improvements in a final report.

Address Secondary Issues Assigned to PA Maintenance from the LFRG Review of the ELLWF PA. The LFRG review of the ELLWF PA was conducted in November 2007. The review team issued their final report which recommended approval of the ELLWF PA without conditions (DOE, 2008a). However, the report contains numerous secondary issues that must be tracked and resolved through PA maintenance. The issues and associated resolution reported in the LFRG Review Team report are reproduced in Appendix B of the 2009 ELLWF PA (WSRC, 2008b) and CA Maintenance Plan (Crapse, 2009). SRNL will continue to work through these issues and document their resolution in FY2011.

Maintain Computer Codes, Models, Programs and PA Baseline Documentation. Computer models consist of computer files, assumptions, and much supporting work. This information needs to be well organized and carefully preserved to allow checking published results and to make changes in the most cost-effective manner. Computer files generally are preserved, but often it may be difficult to readily identify which files represent the final product and to determine the order in which to process the files. Solid documentation and well-defined storage methods will prove highly beneficial. The following are aspects of the QA process that will be addressed in FY2010 and beyond:

- $\quad$ QA documentation. SRNL will continue to maintain and upgrade software QA as needed to stay in compliance with site software QA requirements.

- $\quad$ RWMB database. In FY2006, SRNL developed a PA limits database for SWM and SRNL to jointly maintain. This database contains the latest disposal unit limits and associated references to eliminate confusion over limit changes. This database will continue to be updated as needed.

- Training and Software. In FY2011 SRNL will purchase the necessary software license renewals and maintenance contracts for the various codes used in PA work.

- Data management. SRNL prepared a data management plan for archiving performance assessment models and data in FY09. SRNL completed populating the PA archive with models and data from the 2008 PA in FY10. The PA archive will continue to be maintained and updated with results from new Special Analyses and UDQE's in FY11

Implement Monitoring Based on PA Monitoring Plan. SRNL prepared a monitoring plan for the ELLWF (Millings, 2009a)) to meet the requirements for monitoring LLW disposal facilities according to DOE Order 435.1 and its associated implementation guidance. The key elements of a PA monitoring program that must be addressed are:

- The site-specific PA shall be used to determine the media, locations, radionuclides, and other substances to be monitored.

- The environmental monitoring program shall be designed to include measuring and evaluating releases, migration of radionuclides, disposal unit subsidence, and changes in disposal facility and disposal site parameters which may affect long-term performance.

- The environmental monitoring programs shall be capable of detecting changing trends in performance 
SRNS-STI-2011-00024, Revision 0

to allow application of any necessary corrective action prior to exceeding the PA performance objectives.

As outlined in this plan, monitoring for the ELLWF consists of evaluating groundwater, sump water, vault concrete and subsidence, and vadose zone pore water. The plan specifies monitoring locations, sampling frequencies and methods, analytical methods and action levels. SRNL facilitates the bi-annual VZ sampling and analysis by interfacing with the onsite laboratory. In FY09-10 SRNL set up a bar code system to standardize the name for each lysimeter and depth, and to streamline data entry. SRNL maintains the VZ monitoring database and evaluates and interprets the data as part of the annual PA monitoring validation exercise.

SRNL is periodically requested to perform other monitoring to collect confirmatory data or expand the existing program. Examples of monitoring to confirm system performance may include; periodic sampling of an expanded list of radionuclides in vadose zone lysimeters, neutron probe studies of soil moisture, water table elevation studies, vault concrete cracking studies and targeted air monitoring. Potential expansion of the monitoring program may consider innovative monitoring approaches such as potential additives to engineered features that could be detected and indicate a change in performance. Results of studies will be documented in reports and/or summarized in the PA-CA Annual Review.

PA and CA Maintenance Program. This program has been developed and is updated annually to meet the requirements for maintenance of PAs of DOE LLW disposal facilities and CAs in accordance with DOE Order 435.1. The plan identifies the maintenance program needed to provide greater confidence in the results of the analyses and to address potential changes in disposal operations. Included are activities in the areas of UDQE, SAs, PA/CA revisions, PA/CA reviews, monitoring and closure, and test and research over a ten-year period. In FY10 the SRS PA/CA Maintenance Plan was split between facilities managed by SRNS and those managed by SRR, the new Liquid Waste Operations (LWO) contractor. SRNL, SWM and RI\&ES will jointly produce the FY11 update for the CA and ELLWF. SRR will produce a separate plan for the SDF, F-Area Tank Farm (FTF) and HTF Closure.

Support Preparation of the ELLWF PA Annual Review. PA reviews have been conducted annually since FY1998. The PA review will be conducted in a systematic manner that incorporates all of the following considerations:

1) Radionuclide Inventories, Waste Volumes, and Waste Types - The review of waste radionuclide inventories and waste volumes will include a comparison of the actual waste receipt to that projected in the PA. Future waste receipts as estimated in the waste forecast report will also be considered.

2) Results of Monitoring - PA monitoring data (i.e., vadose zone wells, groundwater, sump water, vault integrity, trench covers) from the previous year will be reviewed to determine the impact of ELLWF operations on the surrounding environment and integrity of engineered barriers.

3) Past and Future R\&D Events - R\&D events from the past year will be reviewed. These are primarily documented in SAs, UDQEs, preliminary studies and other PA baseline documents. The review will also consider expected future activities in terms of their significance to disposal operations and the adequacy of the PA in representing facility performance relative to performance objectives.

4) Other Relevant Factors - Other operational and design considerations that may be relevant to the review of the PA are listed in the DOE Order 435.1 guidance. Important features reviewed each year include; disposal geometry, waste types/packaging, WAC, WITS, provisions for performance monitoring, new disposal technologies, engineered barriers, structural stability, other design features, and future land use plans.

All of these factors will be reviewed annually to evaluate the need to conduct special studies or revise baseline PA documentation. A report will be generated each year documenting the results of the review.

Update ELLWF Closure Plan. SRS LLW management is regulated under DOE Order 435.1. DOE-HQ signed revision 1 of the Disposal Authorization Statement on 7/15/2008 authorizing continued operation of the SRS ELLWF. The DAS conditions of approval include a requirement to revise the ELLWF closure plan as necessary to address any deviations from the closure concept analyzed in the PA. The closure plan 
was revised in 2009 to align with the closure concept evaluated in the 2008 revision of the ELLWF PA and subsequent Special Analysis of Operational Stormwater Runoff Covers Over Slit Trenches (Collard and Hamm, 2008). Going forward the Closure Plan will be reviewed annually to determine if actions taken during the previous year or new information results in the need for changing the closure concept.

\subsection{Other Relevant Factors}

\subsubsection{Operations, Facility Closure and Design}

The purpose of the annual PA review is to routinely assess the adequacy of the PA. Many elements are important in determining that the PA is adequate. DOE guidance on PA maintenance indicates that, in addition to an evaluation of the results of monitoring and test and research and development programs (see Sections 3.2 and 3.3 of this report), other factors may be relevant to the determination of PA adequacy that include operational design considerations. Table 10 gives a list of "other relevant factors" and the status of their consideration in this PA Review. 
SRNS-STI-2011-00024, Revision 0

Table 10. Status of Other Relevant Factors

\begin{tabular}{|c|c|c|}
\hline $\begin{array}{c}\text { Type of Relevant } \\
\text { Factor }\end{array}$ & $\begin{array}{l}\text { Relevant } \\
\text { Factor }\end{array}$ & Status \\
\hline \multirow{4}{*}{ OPERATIONS } & $\begin{array}{l}\text { Disposal } \\
\text { Geometry }\end{array}$ & $\begin{array}{l}\text { This factor considers disposal geometry such as depth of trench, waste } \\
\text { profile, thickness of backfill and trench orientation. Completely new } \\
\text { disposal unit models were developed for the } 2008 \text { ELLWF PA revision. } \\
\text { The principal design features and disposal unit characteristics were } \\
\text { incorporated into these new models. In addition, changes to disposal unit } \\
\text { geometry as a result of waste layer and barrier degradation were features of } \\
\text { the long term performance. Several SA's and UDQE's have been approved } \\
\text { since then, however, only two deal with disposal geometry changes; 1) a } \\
\text { UDQE evaluating disposal of two 'tall' used equipment storage boxes in } \\
\text { ST8, and 2) a UDQE evaluating closure and replacement of the sump in } \\
\text { Engineered Trench \#1, both approved in } 2009 \text {. No changes or exceptions to } \\
\text { the baseline disposal geometry were approved in FY10. One study was } \\
\text { completed that evaluated the impact of Slit Trench spacing on infiltration } \\
\text { estimates. Work planned for or being completed in FY11 will consider the } \\
\text { following; } 1 \text { ) disposing of additional 'tall' used equipment storage boxes in } \\
\text { Slit Trenches } 8,9 \text { and } 10 \text {, and } 2 \text { ) spatial and temporal variations in waste } \\
\text { disposed in Slit Trenches } 1 \text { - 5. (See sections 3.3.1.3, 3.3.2.1 and 3.3.2.2.) }\end{array}$ \\
\hline & $\begin{array}{l}\text { Waste Type/ } \\
\text { Packaging }\end{array}$ & $\begin{array}{l}\text { This factor considers the effect of waste packaging or the waste form itself } \\
\text { on release of radionuclides to the environment. The FY2008 ELLWF PA } \\
\text { considered both generic waste forms and special waste forms for the } \\
\text { groundwater analysis. For radionuclides associated with special waste } \\
\text { forms, release mechanisms may not be assumed to be instantaneous, and } \mathrm{K}_{\mathrm{d}} \\
\text { values may differ from that of generic waste to account for the presence of } \\
\text { ion-exchange resins in the waste form, or rate-limiting processes such as } \\
\text { diffusion, dissolution and/or corrosion. Several SA's and UDQE's have } \\
\text { been approved since the 2008 PA but only one dealing with waste form; } \\
\text { i.e., a Special Analysis of IL Vault disposal of two defense programs waste } \\
\text { streams approved in FY09. This analysis takes into account the sealed } \\
\text { stainless steel boxes in setting waste form specific air limits. In addition } \\
\text { several studies were completed in FY10 to determine waste form durability } \\
\text { that support ongoing SA's or address closure considerations. They include; } \\
\text { 1) an ETP Carbon Vessel post burial structural and corrosion assessment, } \\
\text { 2) a Heavy Water Components Test Reactor supporting structural } \\
\text { calculation, and 3) a rapid response evaluation of onsite disposal options } \\
\text { for HWCTR. Another study was completed that provides a revised hybrid } \\
\text { Slit Trench waste representation that combines bulk waste and } \\
\text { containerized waste. (See section 3.3.1.3.) }\end{array}$ \\
\hline & WAC & $\begin{array}{l}\text { PA controls, such as the WAC, are discussed in this section. Discussions } \\
\text { on radionuclide inventories vs. the facility limits are included in Section } \\
\text { 3.1. A revision to the E-Area Low-Level Waste Facility Disposal Limits } \\
\text { Database has been developed and is accessible from the Solid Waste } \\
\text { Management homepage on ShRINE. This latest revision incorporates new } \\
\text { limits from the Special Analysis of Tritium Disposal Limits for E-Area Slit } \\
\text { Trench } 4 \text { (See section 3.3.1.4.) }\end{array}$ \\
\hline & $\begin{array}{c}\text { Control } \\
\text { Procedures }\end{array}$ & $\begin{array}{l}\text { Important control procedures are discussed in this section (Section 3.4.2). } \\
\text { Section 3.4.2.2 describes new key operational I\&A that were implemented } \\
\text { in FY10 and how they are being protected. }\end{array}$ \\
\hline
\end{tabular}


SRNS-STI-2011-00024, Revision 0

\begin{tabular}{|c|c|c|}
\hline $\begin{array}{l}\text { Type of Relevant } \\
\text { Factor }\end{array}$ & $\begin{array}{l}\text { Relevant } \\
\text { Factor }\end{array}$ & Status \\
\hline \multirow{5}{*}{$\begin{array}{l}\text { FACILITY/ } \\
\text { CLOSURE } \\
\text { DESIGN }\end{array}$} & $\begin{array}{c}\text { Disposal } \\
\text { Technologies }\end{array}$ & $\begin{array}{l}\text { The } 2008 \text { ELLWF PA evaluated six different types of disposal units } \\
\text { providing different degrees of waste isolation depending on the wasteform } \\
\text { and radionuclide inventory. Disposal technologies are being planned } \\
\text { beyond what was already analyzed in the } 2008 \text { ELLWF PA. In FY } 10 \\
\text { SRNL completed a re-assessment of the condition of the Bamboo Nursery } \\
\text { that was established in } 1991 \text {. The possible use of bamboo as a closure cap } \\
\text { vegetation species was evaluated and possible future research and } \\
\text { operational issues were identified. (See section 3.3.1.3.) }\end{array}$ \\
\hline & $\begin{array}{l}\text { Engineered } \\
\text { Barriers }\end{array}$ & $\begin{array}{l}\text { Long-term performance of engineered barriers is an integral part of the } \\
2008 \text { ELLWF PA. Barriers evaluated in the PA range from the waste form } \\
\text { itself (e.g., naval reactor shipping casks), to the disposal unit (e.g., concrete } \\
\text { vaults), to the closure system above the unit. Several SA's and UDQE's } \\
\text { have been approved since the } 2008 \text { PA dealing with engineered barriers } \\
\text { including the } 2008 \text { SA evaluating operational storm water runoff covers for } \\
\text { the first time in FY09, and in FY10, the SLIT4 SA which accounted for } \\
\text { operational stormwater covers in setting limits for tritium in SLIT4 and the } \\
\text { LAW Vault Cell } 11 \text { concrete anchors UDQE. In addition several studies } \\
\text { were completed in FY10 relating to engineered barriers including; 1) a } \\
\text { literature search to identify references related to closure cap drainage layer } \\
\text { long-term hydraulic performance, 2) E-Area Concrete and Grout Durability } \\
\text { Simulations by SIMCO Technologies and 3) Proof-of-Concept Modeling of } \\
\text { Cracked Porous Medium by Clemson University. (See sections 3.3.1.1, } \\
\text { 3.3.1.2 and 3.3.1.3.) }\end{array}$ \\
\hline & $\begin{array}{l}\text { Other Design } \\
\text { Features }\end{array}$ & $\begin{array}{l}\text { The ELLWF PA monitoring program employs a variety of monitoring } \\
\text { approaches and technologies to help verify that the operations and actual } \\
\text { radionuclide releases are in line with the modeling assumptions and } \\
\text { projected releases from the } 2008 \text { ELLWF PA. In FY10, SW and SRNL } \\
\text { completed selected lysimeter demolitions and modification at Slit Trenches } \\
1 \text { - } 5 \text { to accommodate the installation of stormwater covers. This change } \\
\text { simplified the lysimeter network by demolishing all but the most critical or } \\
\text { best performing lysimeters. (See section 3.3.1.3.) }\end{array}$ \\
\hline & $\begin{array}{l}\text { Structural } \\
\text { Stability }\end{array}$ & $\begin{array}{l}\text { Operational controls (e.g., filling voids) and waste subsidence treatments } \\
\text { (e.g., dynamic compaction) prior to final closure will enhance stability of } \\
\text { the waste layer and final closure cover. In FY10 a number of studies were } \\
\text { completed evaluating structural stability including; 1) conditions impacting } \\
\text { corrosion of discarded ETP Carbon Vessels, 2) an ETP Carbon Vessel post } \\
\text { burial assessment, and 3) a Heavy Water Components Test Reactor } \\
\text { supporting structural calculation. Each of these studies dealt with } \\
\text { conditions leading to hydraulic failure and final collapse of the subject } \\
\text { waste form. (See section 3.3.1.3) }\end{array}$ \\
\hline & $\begin{array}{l}\text { Future Land } \\
\text { Use }\end{array}$ & $\begin{array}{l}\text { The SRS Future Use Plan indicates that the current SRS boundaries will } \\
\text { remain unchanged. The land will remain under the ownership of the } \\
\text { federal government. Thus no member of the public would have } \\
\text { unrestricted access to the ELLWF. Nonetheless, the ELLWF PA has used } \\
\text { the point of maximum calculated dose outside a 100-m buffer zone } \\
\text { surrounding the disposed waste as the POA consistent with the } \\
\text { requirements of DOE } 435.1 \text {. For the intruder calculations, the assumed } \\
\text { period of active institutional control was limited to } 100 \text { years. No SA's, } \\
\text { UDQE's or preliminary studies considered alternative land use strategies in } \\
\text { FY10. }\end{array}$ \\
\hline
\end{tabular}


SRNS-STI-2011-00024, Revision 0

\subsubsection{PA Controls}

\subsubsection{WAC and WITS}

The ELLWF WAC serves as the primary administrative control for PA implementation and compliance. The ELLWF WAC, 1S Manual Procedure 3.17, serves as the principal means of communicating PA inputs and assumptions, radionuclide limits, waste form and waste packaging requirements to waste generators (SRS, 2009). In capturing these necessary PA requirements, the WAC also incorporates criteria derived from DOE Order 435.1, facility safety documentation and operational constraints (e.g., compatibility with waste handling equipment). In accordance with site procedures, the WAC is revised and updated at least every two to three years through revisions or more frequently to implement new PA analyses or facility operational changes. Based on the new PA (WSRC, 2008b), the WAC revision (Rev. 11) was issued on January 15, 2009. The WAC also allows for waste generator submitted deviation requests which, if approved, allow waste generators to deviate from specific criteria. All WAC revisions and deviation requests require documented technical reviews (WSRC, 2008d) to ensure compliance with source documents (i.e., PA, Safety, DOE Orders).

In consideration of the inventory control impacts from the facility safety documentation and the PA, it is no longer feasible or appropriate to establish a simple set of WAC package screening limits within the WAC. Waste generators have access to the complete list of limits for each disposal facility via the WITS program. Waste generators are encouraged to utilize the WITS limit check function at the time of package creation in WITS to determine the appropriate ELLWF disposal location. To ensure PA compliance, the WAC requires that waste generators consider all PA limiting radionuclides in characterizing their waste streams. Complete lists of PA disposal limits are available in the latest approved PA document, which is posted on the SWM Home Page for waste generators' use. Before containers are shipped for emplacement in the various vaults or trenches, the contents are entered into WITS by the waste generators. WITS compares the package contents with the WAC container limits, calculates the cell/facility inventory (to ensure compliance with the cell criticality and safety-based limits), and calculates the total inventory for each radionuclide to ensure compliance with the limits derived from all pathways in the PA. The limits are tracked as fractions of the individual radionuclide limits. The sums of these fractions for each disposal unit are maintained less than or equal to one to ensure compliance with all of the limits. The waste generators, through implementation of their certification program described below, certify compliance with these criteria on each waste shipment manifest.

The waste form/type and packaging or container requirements as specified by the PA and safety-related documents are controlled also through WITS. All approved waste containers and types are listed in WITS requiring the waste generator to select the appropriate one. If the waste generator's waste type/container is not listed in WITS, a Container Approval Request is submitted, as discussed in the deviation procedure in Section 3.4.2.6.

Two elements of WITS that ensure that the PA limits are being protected are the software QA and the selfprogrammed "limit-checking system." WITS software was developed under Quality Assurance Procedure (QAP) 20-1 (QAP 20-1) and the SRS E7 Manual, Conduct of Engineering (SRS, 2008) to ensure that it met the standards of the most rigorous software configuration control. Maintenance of WITS is conducted to high QA and configuration control software standards as required by the SRS E7 Manual (SRS, 2008).

\subsubsection{Review, Validation \& Protection of Inputs and Assumptions}

The current PA, Closure Plan and all subsequent SAs and UDQEs (as applicable) identify I\&As which define limits and conditions in PA space which must be protected. SWM Engineering identifies and maintains the PA I\&As using procedure SW-ENG-0703, "Documentation, Validation, and Protection of Inputs and Assumptions" (SWM, 2009a). This procedure defines the process of identification, review and implementation of all I\&As for the SWM Facilities' DSA and the PA. The procedure directs SWM 
Engineering to initiate the I\&As identification and update process, document each I\&A on separate I\&A data sheets, and validate that approved protective measures are implemented where appropriate (i.e., procedures, drawings, documents, etc.). All PA data sheets are reviewed and approved by the SWM Facility Manager and Engineering Management prior to entering into the PA I\&A data base. An evaluation of any new LLW activity, including Unreviewed Disposal Question (UDQ) Screenings, requires a review of the PA I\&A data base to confirm the new proposed activity will not impact any PA I\&A. Any impacts would require notification of SRNL for the need of an UDQE to address the issues. Currently, SWM is in compliance with the PA I\&As for FY2010.

SA's are performed to evaluate the significance of new information to the results of the PA or CA, or to supplement or amend the analyses performed in the original analysis. An SA is not the same as a revision to the PA or CA, but the results of the SA may be used to determine whether a PA or CA revision is needed. From an operating program standpoint, SAs may be necessary to evaluate whether certain actions or changes can be made. The following indicate the types of changes that could necessitate an SA in support of operations:

- $\quad$ disposal of radionuclides not analyzed in the PA;

- $\quad$ disposal of waste streams not analyzed in the PA;

- $\quad$ changes in waste forms that could increase release rates for critical radionuclides;

- $\quad$ wastes that exceed the concentrations analyzed for PA-significant radionuclides;

- $\quad$ wastes that cause the site to exceed the total inventory analyzed for PA-significant radionuclides; and

- $\quad$ changes in the disposal facility design or operations from those described in the PA.

The UDQ process was developed so that proposed changes and discoveries such as those described above are considered in a disciplined manner to ensure they do not adversely affect disposal facility performance. If the UDQ Evaluation determines that such a change can be accommodated within the existing assumptions of the PA or CA and does not result in the need to revise radionuclide disposal limits or reassess dose impacts then the evaluation stops there. If, on the other hand, the evaluation determines that the assumptions of the original PA or CA are violated or that analysis of new disposal limits or dose impacts is required then an SA is performed. A CA UDQE and/or SA will be conducted whenever changes in the inputs or assumptions in the CA occur (e.g., changes in residual inventory estimates for site facilities, updates of land-use plans).

In FY2010 SRNL produced one SA and one UDQE which generated six new key I\&As. These new I\&As were identified by a comparison of the proposed action/new information with the I\&A of the 2008 PA. Based on the UDQ program for controlling the PA and CA baseline, and the system for documenting key I\&A and validating that protective measures are implemented by SWM, the proposed changes/new information from FY2010 are within the bounds of the PA/CA baseline. 


\subsubsection{Waste Certification Process}

Waste certification is the process used at SRS to ensure that the waste is characterized properly and that Treatment, Storage and Disposal (TSD) WAC requirements are met prior to disposal. The following sections summarizing the waste certification process are excerpted from Procedures $1.02 \& 2.02$ of the SRS 1S Manual (SRS, 2009) and Procedure SW-WCAM-4, "SRS Certification Program Review for Radioactive Waste Generators" (SWM, 2009c). The sections below describe the elements of the waste certification process and the waste certification program deficiencies identified in FY2010 and the subsequent corrective actions that were implemented.

\subsection{Elements of the Waste Certification Process}

The waste certification process includes waste generator's waste management program development, SWM assessment and approval of the generator program, and a continuous improvement process consisting of periodic assessment by the SRNS FEB, generator self-assessments \& waste certification surveillances, SWM Point of Contact (POC) feedback, and SWMF receipt inspection/verification. The elements of the waste certification process are listed/described below in Sections 3.4.2.3.2 through 3.4.2.3.4.

\subsection{Generator Waste Management Program Development}

Generator waste management program development includes the following areas:

- Establishment of the waste organization

- Generator Certification Official (GCO) qualification

- Cognizant Technical Function (CTF) qualification

- Certification plan development and approval

- Proper identification of waste streams

- Proper characterization of waste streams

- Waste stream segregation

- Procedure development

- Training program development

- QA program development

- Program implementation

The cornerstone of the waste management program relies predominately on the knowledge and experience of the GCO. The GCO ensures all the waste management functions are carried out with the required rigor and detail of the specified requirements. The GCO also is the primary inter-organizational interface, who coordinates activities for waste shipments. Enhancements to waste management processes such as more cost-effective handling methods, new technologies for characterization and waste minimization typically depend heavily on GCO initiative, knowledge and coordination.

SWM is the independent organization responsible for development and coordination of the GCO core and continuing training program. SWM maintains a qualified GCO list for each waste generator facility. Only qualified GCOs can approve and sign a manifest for a waste package shipment.

\subsection{Program Approval}

Newly developed waste generator's waste certification programs are initially evaluated by a team of subject matter experts from SWM. In a two-part assessment process SWM will confirm that the waste generator's program, as documented in waste certification plans/procedures, meets the requirements of the applicable TSD and DOE Order 435.1. The first part of the assessment is primarily programmatic since actual radioactive waste has yet to be generated. This consists of document reviews, facility walk-downs, and personnel interviews. Findings resulting from the assessment are forwarded to the facility for disposition. 
With satisfactory resolution of noted findings, a memorandum is issued to the facility granting conditional approval to characterize and generate waste. Concurrent with the assessment, the waste generator submits WSCFs to SWM for review and approval. When actual waste is generated and ready for packaging, SWM will return to conduct a performance based assessment and monitor the processing, packaging and shipping of the waste. With satisfactory resolution of any noted findings, the waste generator's waste certification program is granted final approval.

\subsection{Periodic Assessment}

The FEB provides an assessment of each SRS facility including waste management activities on a periodic basis. The FEB is comprised of subject matter experts and reports directly to the SRNS President. Periodic assessments of waste generator's waste certification programs are included in the scope of the FEB assessments. FEB assessments were performed on nine (9) waste generators during FY2010. The assessments ranged in periodicity from eighteen (18) to thirty-six (36) months. The frequency is based on the facility's rating from the previous FEB review and the hazard classification for the facility. SWM personnel participate on the FEB assessments as Subject Matter Experts for the review of waste certification programs. Upon completion of each FEB assessment, SWM meets with the facility waste management personnel to discuss findings, observations, and good practices and to identify a path forward for tracking the closure of identified findings. The FEB report includes the items presented at the meeting and serves as the vehicle for tracking progress of disposition of these items.

\subsection{Continuous Improvement Program}

The waste certification continuous improvement program consists of the periodic FEB assessments described above as well as waste generator self-assessments, waste certification surveillances, SWM POC feedback, and SWMF receipt inspection/verification. Waste generators are responsible for periodically checking the effectiveness of their waste certification programs through the use of a self-assessment program.

SWM has assigned POCs to each of the certified waste generating facilities at SRS. These personnel provide technical assistance to the waste generators in all areas of waste management, including waste certification. POCs work closely with the waste generator and develop a working knowledge of the waste generator's program and are helpful in providing feedback on the current status of a program. Significant findings requiring immediate attention identified during the FEB assessments are tracked by the POC until closure.

Inspection/verification of waste packages received at the SWM TSD facility ensures compliance with the TSD WAC. These final inspections also include review of manifests and other documentation.

The SWM PARC reviews each new evolution concerning LLW storage and disposal as defined in SW Procedure SW-AP-1407 "Performance Assessment (PA) Review Committee", (SWM, 2009d). Each UDQE and each SA is specifically reviewed by the PARC. This committee approval is required for each UDQE and each SA prior to implementation of any new proposed action or in the event of a discovered condition that may not be within the bounds of the approved PA.

The DOE-SR monitors every proposed activity to ensure activities are conducted within the bounds of the PA and specifically approves each SA. The DOE representatives are directly involved in reviewing all activities, including attending both SWM Facility Operations Safety Committee (FOSC) and SWM PA Review Committee meetings to provide input and feedback to evolutions and "lessons learned" as a result of Site Item Reportability and Issue Management (SIRIM) events.

\subsubsection{Evaluation/Trending of the Waste Certification Process}

The quarterly waste certification performance metrics and integrated management evaluation provides an effective and timely means to gauge the status of both individual waste generator programs and the waste certification program site-wide. 
SRNS-STI-2011-00024, Revision 0

To qualify the data obtained from the waste certification performance metrics and place it in a context which interprets and places perspective on what is deemed acceptable performance, a comparative risk analysis has been performed involving specific elements of the waste certification process. Analysis results are weighted according to relative risk (i.e. administrative/programmatic deficiency, environmental impact potential, employee/public safety potential) and assigned a measurable value (excellent to poor).

Evaluation results are rolled up into an overall waste certification program grade that is reported to DOE. The FY2010 waste certification program performance trend resulted in an overall "GOOD" performance rating.

\subsubsection{SIRIM Events}

A review was conducted of the SWM SIRIM database to evaluate events related to waste disposal and the potential impact on the PA bases and conclusions. In FY2010, one event occurred pertaining to SWM handling LLW. SIRIM event EM-SR-SRNS-CPWM-2010-0002 was reported on February 1, 2010 and involves seven B-25 waste containers were inadvertently disposed in a slit trench in the SWMF due to dual labels being placed on the containers. Disposal of these containers caused the radiological inventory in the specific slit trench to exceed the PA disposal limits. When the error was discovered, five of the containers were located inside an uncovered trench segment, and the other two containers were in a segment already covered with soil.

SRNL completed an Special Analysis in May to support approval for returning one of the STs to operation. Operations at ST 4 had been halted due to inadvertent disposal of waste that did not meet the WAC for tritium. SWM discovered seven packages of LLW were incorrectly placed into ST 4 because of incorrect container labeling. Five of the waste packages were located in an area that had not yet been covered with soil and four of these packages were retrieved. The fifth package was determined to be within waste acceptance criteria and was not retrieved. The remaining two waste packages were in a section of the trench that has been covered with soil. SWM planning efforts to retrieve the remaining two waste packages had begun; however, the work promised to be much more hazardous and operationally challenging than the retrieval of the first four waste packages and would have resulted in the trench being out of operation for three to six months at a cost of $\$ 1-2 \mathrm{M}$. The modeling conclusively demonstrated the tritium inventory from these two waste packages is well within new tritium groundwater limits established in this SA. SRNL presented the results of the SA to the SWM Performance Assessment Review Committee (PARC) and received approval on May 12, 2010. The Committee and DOE approved the SA and SWM returned ST 4 to operation on May 25, 2010 at a significant reduction in cost and risk to personnel. In addition, changes were made in an operating procedure which involved adding a peer review for all decisions made on container issues found in the field.

To address any future errors of the dual label issues on containers, SWM has initiated a procedural requirement for dual confirmation by SW Engineering of label issues on suspect containers found in the field.

\subsubsection{Deviations}

\subsection{Deviation Process}

The WAC discussed in this section has a formal procedure for allowing waste generators to waive specific requirements that cannot be met or are not applicable. The waste generator initiates the deviation process by filling out a Deviation Request Form and forwarding it with any supporting documentation to SWM. The cognizant SWM engineer for the affected facility evaluates the request and performs a technical review that will include an Unreviewed Safety Question (USQ) for review in Safety Authorization requirements and UDQ for review in PA requirements. The SWM engineer is also required to obtain review from other organizations, where needed, such as QA, Waste Certification, or Radiological Controls. Upon completion of the technical review, the SWM engineer makes a recommendation for approval or disapproval of the Deviation Request and forwards documentation to the SWM Facility Manager. If the SWM Facility 
SRNS-STI-2011-00024, Revision 0

Manager concurs with the Deviation Request recommendation for approval, it is then authorized for implementation.

\subsection{Container Approval Requests}

Greater than $90 \%$ of the waste containers received in the ELLWF are standard B-25/B-12s. The WAC does allow consideration for "nonstandard" containers such as drums and specialty overpacks to be used. The "Container Approval Request" form, which is submitted by the waste generator, is subjected to a review/approval process similar to that of the Deviation Request. The SWM engineering review ensures that the proposed container conforms to the PA and safety requirements such as construction material, structural integrity, loading capacity, and maximum allowable floor loading. For the Naval Reactor pads, the request also emphasizes safe transport and handling of the radioactive components. 281 containers have been approved for use in the ELLWF, though many were approved for one-time use only. The PA does not require containerization of soil, wood, or rubble prior to disposal in the trenches.

\subsection{Summary of Deviations}

One (1) deviation request was processed and approved in FY2010. The deviation request concerned void space and was evaluated against specific criteria before acceptance. The deviation request had no impact on the PA. 


\subsection{COMPOSITE ANALYSIS ANNUAL DETERMINATION}

\subsection{SOURCES OF RESIDUAL RADIOACTIVE MATERIAL}

In July 2010 DOE-HQ approved a new SRS Composite Analysis (SRNS, 2010c). Since the site operated under the original 1997 CA (WSRC, 1997) for most of FY10 this annual review is being performed against the original CA. Compliance with the 2010 CA will be evaluated for the first time in next year's annual review.

The 1997 CA (WSRC, 1997) analyzed all sources of residual radioactive material in the SRS GSA. The GSA encompasses the central part of the SRS and includes all of the waste disposal facilities, chemical separations facilities and associated HLW storage facilities as well as numerous other sources of radioactive material.

The sources included in the analysis (i.e., those not screened out) are listed in Table 11. Of these, only the MWMF, the ORWBG, and the HLW tanks contribute significantly to the doses calculated in the 1997 CA. Since publication of the CA, there have been no significant changes in any of these facilities that would alter the analysis or conclusions of the CA.

Table 11. CA Sources of Residual Radioactive Material

\begin{tabular}{|c|l|l|l|}
\hline \multirow{5}{*}{ E-Area } & Lysimeters & \\
& MWMF & \\
& Naval Fuels Waste & Canyon (Separations) \\
& Naval Reactors Knolls Atomic Power & & Laboratory (KAPL) Core \\
& Barrels/Thermal Shields (CB/TS) & ETP Receipt Tank \\
& Naval Reactors KAPL Head & Inactive Process Sewer Lines \\
& ORWBG & H-Area Tanks (9-12, 13-16, 21-24 29- \\
& Old Solvent Tanks S1-S22 & 32, and 35-37, 38-43, and 48-51) \\
& Saltstone Lysimeters & New solvent tanks (H33-36) \\
& E-Area Trenches & Sand Filter \\
& Solvent Tanks S23-S30 and S32 & Seepage Basin GW Operable Unit \\
& LAW Vaults & Tritium Processing (232, 233, and 234- \\
& IL Vaults & H) \\
\hline \multirow{5}{*}{ F-Area } & 235-F & \\
& $772-F$ & & \\
& $772-1 F$ & & \\
& Canyon (Separations) & & \\
& F-Area Tanks (1-8, 17-20,25-28 and & S-Area & DWPF \\
& 44-47, 33-34) & & Low Point Pump Pit \\
& Inactive Process Sewer Lines & & \\
& Sand Filters & & \\
& Seepage Basin GW Operable Unit & & Tanks 3, 8, 9, 13, 16 \& 37 \\
\hline \multirow{2}{*}{ Z-Area } & SDF & Sarious & B281-3F \\
\hline
\end{tabular}




\subsection{LAND USE}

The SRS land use plan does not envision unrestricted use of any of the current land within the SRS boundaries. There have been no changes in the SRS land use planning since publication of the CA. Thus, from the perspective of land use, there have been no changes that would alter the analysis or conclusions of the CA.

\subsection{COMPOSITE ANALYSIS MONITORING}

The CA monitoring plan is being implemented to meet the requirements for monitoring LLW disposal facilities according to DOE Order 435.1. In particular, the $1997 \mathrm{CA}$ was used to determine the media, locations, and radionuclides to be monitored. The results of the monitoring program are designed to detect changing trends in performance to allow application of any necessary corrective action prior to exceeding the CA performance objectives.

The CA monitoring plan was revised in FY2009 (Crapse, 2009). This annual assessment of CA monitoring results for FY2010 reflects these revisions. DOE approved a complete revision to the CA on June 10, 2010 that was more comprehensive and included all source terms expected to remain at SRS across the entire site. As a result a companion monitoring plan is under development.

The 1997 CA determined that the only significant migration pathway is groundwater that discharges to surface water streams. The only potential exposure pathway for the public is through exposure to surface water. Therefore, monitoring of groundwater was performed in close proximity to the facilities identified in the CA as primary contributors of contaminant flux to the groundwater (i.e., the ORWBG, MWMF, and the HTF). Monitoring of the surface water in Upper Three Runs and Fourmile Branch was performed to evaluate the projections in the $1997 \mathrm{CA}$ for the composite effects of all facilities considered. Table 12 summarizes the monitoring locations, radionuclides and other substances to be monitored, and corresponding action levels reflecting changes incorporated in the revised Composite Analysis Monitoring Plan for the ELLWF and the Z-Area SDF (Crapse, 2009). The action levels for tritium for stream monitoring locations are based on $25 \%$ of the projected peak stream concentrations for Fourmile and Upper Three Runs as calculated in the 1997 CA. The action levels for gross alpha, nonvolatile beta, and tritium for groundwater monitoring are based on $25 \%$ of the projected peak groundwater concentrations beneath each facility as calculated in the $1997 \mathrm{CA}$. The action level for nitrate monitoring at HTF is based on $25 \%$ of the MCL for nitrate. 
SRNS-STI-2011-00024, Revision 0

Table 12. CA Monitoring Summary

\begin{tabular}{|c|c|c|}
\hline Monitoring Location & Radionuclide* & Action Level (pCi/L) \\
\hline \multirow{3}{*}{$\begin{array}{c}\text { ORWBG: } \\
\text { BGO-46D, 47D, 48D, 49D, and } \\
50 \mathrm{D}\end{array}$} & Gross alpha & $4.2 \times 10^{+2}$ \\
\hline & Nonvolatile beta & $2.2 \times 10^{+3}$ \\
\hline & Tritium & $7.1 \times 10^{+7}$ \\
\hline \multirow{3}{*}{$\begin{array}{l}\text { MWMF: all BGX-D Wells, } \\
\text { BGO-1D, 2D, 3D, 4D, and 5D }\end{array}$} & Gross alpha & $7.5 \times 10^{+2}$ \\
\hline & Nonvolatile beta & $1.6 \times 10^{+3}$ \\
\hline & Tritium & $7.5 \times 10^{+7}$ \\
\hline $\begin{array}{c}\text { H Tank Farm: HAA4_A,B,D, } \\
\text { HAA7-15 all_A, B, D) }\end{array}$ & Nitrate & $2.5 \mathrm{ppm}$ \\
\hline $\begin{array}{l}\text { Upper Three Runs: } \\
\text { U3R-1A, U3R-4 }\end{array}$ & Tritium & $1.7 \times 10^{+4}$ \\
\hline Fourmile Branch: FM-A7, FM-6 & Tritium & $1.5 \times 10^{+5}$ \\
\hline
\end{tabular}

* Gross alpha based on ${ }^{238} \mathrm{U}$ results. Nonvolatile beta based on ${ }^{14} \mathrm{C}$ results

\subsubsection{Groundwater Monitoring}

\subsubsection{Old Radioactive Waste Burial Ground}

Gross alpha and nonvolatile beta monitoring was not carried out for any of the designated ORWBG monitoring locations in FY2009-2010 (BGO-46D, 47D, 48D, 49D, and 50D) due to changes in Site monitoring program. In previous years results for these monitoring locations were below the action level for both gross alpha and nonvolatile beta. A series of adjacent BGO monitoring locations in closer proximity to the ORWBG (BGO-28D, 30D, 31D, 32D, and 33D) were evaluated as alternates to the locations designated in the CA Monitoring Plan (Crapse, 2009). The results for gross alpha and nonvolatile beta monitoring at the alternate locations are below action levels (See Table 13 and Table 14). In FY2010 tritium monitoring for the designated ORWBG monitoring locations (BGO-46D, 47D, 48D, 49D, and 50D; Table 15) was below the action levels.

\subsubsection{Mixed Waste Management Facility}

At MWMF groundwater monitoring locations measured (all BGX-D wells as well as the BGO wells added in the revision of the CA Monitoring Plan [Crapse, 2009] in order to be consistent with the ground water wells monitored in the E-Area PA Monitoring Plan [Millings, 2009]) measured; Table 13, Table 14, and Table 15, gross alpha, nonvolatile beta, and tritium results were all below action levels. 
Table 13. Gross Alpha CA Monitoring Data

\begin{tabular}{|c|c|c|c|c|c|c|}
\hline $\begin{array}{c}\text { Monitoring } \\
\text { Location }\end{array}$ & Type & $\begin{array}{l}\text { Sampling } \\
\text { Location }\end{array}$ & Sampling Date & $\begin{array}{c}\text { Result } \\
(\mathbf{p C i} / \mathbf{L})\end{array}$ & $\begin{array}{c}\text { Action Level } \\
(\mathbf{p C i} / \mathbf{L})\end{array}$ & $\begin{array}{l}\text { Exceeds } \\
\text { action } \\
\text { level? }\end{array}$ \\
\hline \multirow{5}{*}{ ORWBG } & well & $\mathrm{BGO} 46 \mathrm{D}$ & Not sampled & -- & 421 & -- \\
\hline & well & BGO 47D & Not sampled & -- & 421 & -- \\
\hline & well & $\mathrm{BGO} 48 \mathrm{D}$ & Not sampled & -- & 421 & -- \\
\hline & well & BGO 49D & Not sampled & -- & 421 & -- \\
\hline & well & BGO 50D & Not sampled & -- & 421 & -- \\
\hline \multirow{10}{*}{$\begin{array}{l}\text { ORWBG } \\
\text { (alternate } \\
\text { wells) }\end{array}$} & well & BGO 28D & $1 / 13 / 2010$ & $2.49^{*}$ & 421 & no \\
\hline & well & BGO 28D & $7 / 26 / 2010$ & 5.1 & 421 & no \\
\hline & well & BGO 30D & $1 / 13 / 2010$ & $3.92 * *$ & 421 & no \\
\hline & well & BGO 30D & $7 / 27 / 2010$ & 3.26 & 421 & no \\
\hline & well & BGO 31D & $1 / 13 / 2010$ & $1.53 *$ & 421 & no \\
\hline & well & BGO 31D & $7 / 29 / 2010$ & $7.88 * *$ & 421 & no \\
\hline & well & BGO 32D & $1 / 13 / 2010$ & 15 & 421 & no \\
\hline & well & BGO 32D & $7 / 27 / 2010$ & 11.1 & 421 & no \\
\hline & well & BGO 33D & $1 / 14 / 2010$ & $4.29 * *$ & 421 & no \\
\hline & well & BGO 33D & $7 / 14 / 2010$ & $4.32 * *$ & 421 & no \\
\hline \multirow{15}{*}{ MWMF } & well & BGO 1D & $1 / 13 / 2010$ & $1.08^{*}$ & 756 & no \\
\hline & well & BGO 1D & $7 / 13 / 2010$ & $1.62 * *$ & 756 & no \\
\hline & well & BGO 2D & $1 / 11 / 2010$ & $3.15 * *$ & 756 & no \\
\hline & well & $\mathrm{BGO} 2 \mathrm{D}$ & $7 / 12 / 2010$ & $2.28 * *$ & 756 & no \\
\hline & well & BGO 2D & $7 / 12 / 2010$ & $1.69 * *$ & 756 & no \\
\hline & well & BGO 3DR & $1 / 11 / 2010$ & $3.59 * *$ & 756 & no \\
\hline & well & BGO 3DR & 7/6/2010 & $3.39 * *$ & 756 & no \\
\hline & well & BGO 4D & $1 / 13 / 2010$ & $1.54 *$ & 756 & no \\
\hline & well & BGO 4D & $7 / 14 / 2010$ & $0.89 * *$ & 756 & no \\
\hline & well & BGO 5D & $1 / 11 / 2010$ & $1.39 *$ & 756 & no \\
\hline & well & BGO 5D & $7 / 13 / 2010$ & $1.95^{* *}$ & 756 & no \\
\hline & well & BGX 1D & $7 / 27 / 2010$ & $1.49^{*}$ & 756 & no \\
\hline & well & BGX 2D & $7 / 15 / 2010$ & $1.13^{*}$ & 756 & no \\
\hline & well & BGX 5D & $7 / 14 / 2010$ & $4.34 * *$ & 756 & no \\
\hline & well & BGX 8DR & $7 / 27 / 2010$ & $2.89 * *$ & 756 & no \\
\hline
\end{tabular}

Laboratory counting values are provided on the table; values with * are below the laboratory's quantitation limits (U qualifier); values with ** are below the laboratory's quantitation limits but were able to be estimated (J qualifier). 
SRNS-STI-2011-00024, Revision 0

Table 14. Nonvolatile Beta CA Monitoring Data

\begin{tabular}{|c|c|c|c|c|c|c|}
\hline $\begin{array}{l}\text { Monitoring } \\
\text { Location }\end{array}$ & Type & $\begin{array}{l}\text { Sampling } \\
\text { Location }\end{array}$ & Sampling Date & $\begin{array}{l}\text { Result } \\
(\mathrm{pCi} / \mathbf{L})\end{array}$ & $\begin{array}{c}\text { Action } \\
\text { Level } \\
(\mathbf{p C i} / \mathbf{L}) \\
\end{array}$ & $\begin{array}{c}\text { Exceeds } \\
\text { action level? }\end{array}$ \\
\hline \multirow{5}{*}{ ORWBG } & well & BGO 46D & Not sampled & -- & 2200 & -- \\
\hline & well & BGO 47D & Not sampled & -- & 2200 & -- \\
\hline & well & BGO 48D & Not sampled & -- & 2200 & -- \\
\hline & well & BGO 49D & Not sampled & -- & 2200 & -- \\
\hline & well & BGO 50D & Not sampled & -- & 2200 & -- \\
\hline \multirow{10}{*}{$\begin{array}{c}\text { ORWBG } \\
\text { (alternate wells) }\end{array}$} & well & BGO 28D & $1 / 13 / 2010$ & 24.9 & 2200 & no \\
\hline & well & BGO 28D & $7 / 26 / 2010$ & 16.4 & 2200 & no \\
\hline & well & BGO 30D & $1 / 13 / 2010$ & $7.93 * *$ & 2200 & no \\
\hline & well & BGO 30D & $7 / 27 / 2010$ & 3.94 & 2200 & no \\
\hline & well & BGO 31D & $1 / 13 / 2010$ & $3.29 *$ & 2200 & no \\
\hline & well & BGO 31D & $7 / 29 / 2010$ & $2.64 *$ & 2200 & no \\
\hline & well & BGO 32D & $1 / 13 / 2010$ & $14.8 * *$ & 2200 & no \\
\hline & well & BGO 32D & $7 / 27 / 2010$ & 8.41 & 2200 & no \\
\hline & well & BGO 33D & $1 / 14 / 2010$ & $4.85 * *$ & 2200 & no \\
\hline & well & BGO 33D & $7 / 14 / 2010$ & 3.43 & 2200 & no \\
\hline \multirow{15}{*}{ MWMF } & well & BGO 1D & $1 / 13 / 2010$ & $3.64^{*}$ & 1600 & no \\
\hline & well & BGO 1D & $7 / 13 / 2010$ & $2.2 * *$ & 1600 & no \\
\hline & well & BGO 2D & $1 / 11 / 2010$ & $2.87 *$ & 1600 & no \\
\hline & well & BGO 2D & $7 / 12 / 2010$ & $2.7 * *$ & 1600 & no \\
\hline & well & BGO 2D & $7 / 12 / 2010$ & $2.6^{* *}$ & 1600 & no \\
\hline & well & BGO 3DR & $1 / 11 / 2010$ & $12.4 * *$ & 1600 & no \\
\hline & well & BGO 3DR & $7 / 6 / 2010$ & $3.37 *$ & 1600 & no \\
\hline & well & BGO 4D & $1 / 13 / 2010$ & $4.31 * *$ & 1600 & no \\
\hline & well & $\mathrm{BGO} 4 \mathrm{D}$ & $7 / 14 / 2010$ & $1.14 * *$ & 1600 & no \\
\hline & well & BGO 5D & $1 / 11 / 2010$ & $6.76 * *$ & 1600 & no \\
\hline & well & BGO 5D & $7 / 13 / 2010$ & $1.35^{*}$ & 1600 & no \\
\hline & well & BGX 1D & $7 / 27 / 2010$ & $1.35 *$ & 1600 & no \\
\hline & well & BGX 2D & $7 / 15 / 2010$ & $1.31 *$ & 1600 & no \\
\hline & well & BGX 5D & $7 / 14 / 2010$ & $7.27 * *$ & 1600 & no \\
\hline & well & BGX 8DR & $7 / 27 / 2010$ & $1.29 *$ & 1600 & no \\
\hline
\end{tabular}

Laboratory counting values are provided on the table; values with * are below the laboratory's quantitation limits (U qualifier); values with ** are below the laboratory's quantitation limits but were able to be estimated (J qualifier). 
SRNS-STI-2011-00024, Revision 0

Table 15. Tritium CA Monitoring Data

\begin{tabular}{|c|c|c|c|c|c|c|}
\hline $\begin{array}{l}\text { Monitoring } \\
\text { Location }\end{array}$ & Type & $\begin{array}{l}\text { Sampling } \\
\text { Location }\end{array}$ & Sampling Date & $\begin{array}{l}\text { Result } \\
(\text { pCi/L) }\end{array}$ & $\begin{array}{l}\text { Action Level } \\
\quad(\mathrm{pCi} / \mathrm{L})\end{array}$ & $\begin{array}{c}\text { Exceeds } \\
\text { action } \\
\text { level? }\end{array}$ \\
\hline \multirow{7}{*}{ ORWBG } & well & BGO 46D & Not sampled & -- & $7.1 \times 10^{+7}$ & -- \\
\hline & well & BGO 47D & $7 / 14 / 2010$ & $1.90 \times 10^{+5}$ & $7.1 \times 10^{+7}$ & no \\
\hline & well & BGO 48D & Not sampled & -- & $7.1 \times 10^{+7}$ & -- \\
\hline & well & BGO 49D & Not sampled & -- & $7.1 \times 10^{+7}$ & -- \\
\hline & well & BGO 50D & $1 / 14 / 2010$ & $1.32 \times 10^{+4}$ & $7.1 \times 10^{+7}$ & no \\
\hline & well & BGO 50D & $7 / 14 / 2010$ & $0.90 \times 10^{+4}$ & $7.1 \times 10^{+7}$ & no \\
\hline & well & BGO 50D & $7 / 14 / 2010$ & $0.83 \times 10^{+4}$ & $7.1 \times 10^{+7}$ & no \\
\hline \multirow{19}{*}{ MWMF } & well & BGO 1D & $1 / 13 / 2010$ & $6.17 \times 10^{+3}$ & $7.5 \times 10^{+7}$ & no \\
\hline & well & BGO 1D & $7 / 13 / 2010$ & $6.91 \times 10^{+3}$ & $7.5 \times 10^{+7}$ & no \\
\hline & well & BGO 2D & $1 / 11 / 2010$ & $5.09 \times 10^{+3}$ & $7.5 \times 10^{+7}$ & no \\
\hline & well & BGO 2D & $7 / 12 / 2010$ & $4.7 \times 10^{+3}$ & $7.5 \times 10^{+7}$ & no \\
\hline & well & $\mathrm{BGO} 2 \mathrm{D}$ & $7 / 12 / 2010$ & $4.88 \times 10^{+3}$ & $7.5 \times 10^{+7}$ & no \\
\hline & well & $\mathrm{BGO} 2 \mathrm{D}$ & $7 / 12 / 2010$ & $4.93 \times 10^{+3}$ & $7.5 \times 10^{+7}$ & no \\
\hline & well & BGO 3DR & $1 / 11 / 2010$ & $2.27 \times 10^{+5}$ & $7.5 \times 10^{+7}$ & no \\
\hline & well & BGO 3DR & $7 / 6 / 2010$ & $1.73 \times 10^{+5}$ & $7.5 \times 10^{+7}$ & no \\
\hline & well & BGO 4D & $1 / 13 / 2010$ & $1.08 \times 10^{+6}$ & $7.5 \times 10^{+7}$ & no \\
\hline & well & BGO 4D & $7 / 14 / 2010$ & $1.76 \times 10^{+6}$ & $7.5 \times 10^{+7}$ & no \\
\hline & well & BGO 4D & $7 / 14 / 2010$ & $1.73 \times 10^{+6}$ & $7.5 \times 10^{+7}$ & no \\
\hline & well & BGO 5D & $1 / 11 / 2010$ & $8.48 \times 10^{+6}$ & $7.5 \times 10^{+7}$ & no \\
\hline & well & BGO 5D & $7 / 13 / 2010$ & $7.61 \times 10^{+6}$ & $7.5 \times 10^{+7}$ & no \\
\hline & well & BGX 1D & $1 / 25 / 2010$ & $2.71 \times 10^{+6}$ & $7.5 \times 10^{+7}$ & no \\
\hline & well & BGX 1D & $7 / 27 / 2010$ & $2.57 \times 10^{+6}$ & $7.5 \times 10^{+7}$ & no \\
\hline & well & BGX 2D & $7 / 15 / 2010$ & $1.17 \times 10^{+5}$ & $7.5 \times 10^{+7}$ & no \\
\hline & well & BGX 5D & $7 / 14 / 2010$ & $2.14 \times 10^{+4}$ & $7.5 \times 10^{+7}$ & no \\
\hline & well & BGX 8DR & $1 / 14 / 2010$ & $1.53 \times 10^{+6}$ & $7.5 \times 10^{+7}$ & no \\
\hline & well & BGX 8DR & $7 / 27 / 2010$ & $1.42 \times 10^{+6}$ & $7.5 \times 10^{+7}$ & no \\
\hline \multirow{2}{*}{$\begin{array}{l}\text { Upper Three } \\
\text { Runs }\end{array}$} & stream & U3R-1A & $\begin{array}{c}\text { Mean } \\
\text { (26 samples in 2009) }\end{array}$ & $\begin{array}{l}1.63 \times 10^{2} \\
( \pm 29.4)\end{array}$ & $1.7 \times 10^{+4}$ & no \\
\hline & stream & U3R-4 & $\begin{array}{c}\text { Mean } \\
\text { (12 samples in 2009) }\end{array}$ & $\begin{array}{c}1.24 \times 10^{3} \\
( \pm 52.4)\end{array}$ & $1.7 \times 10^{+4}$ & no \\
\hline \multirow{2}{*}{$\begin{array}{l}\text { Fourmile } \\
\text { Branch }\end{array}$} & stream & FM-A7 & $\begin{array}{c}\text { Mean } \\
\text { (12 samples in 2009) }\end{array}$ & $\begin{array}{c}7.28 \times 10^{4} \\
\left( \pm 2.38 \times 10^{2}\right)\end{array}$ & $1.5 \times 10^{+5}$ & no \\
\hline & stream & FM-6 & $\begin{array}{c}\text { Mean } \\
\text { (12 samples in 2009) }\end{array}$ & $\begin{array}{c}4.52 \times 10^{4} \\
\left( \pm 1.86 \times 10^{2}\right)\end{array}$ & $1.5 \times 10^{+5}$ & no \\
\hline
\end{tabular}


SRNS-STI-2011-00024, Revision 0

\subsubsection{H-Area Tank Farm}

In the 2009 revision to the CA Monitoring Plan (Crapse, 2009), nitrate served as an early indicator of contaminant migration at HTF. Nitrate monitoring locations at HTF (Table 16) were added in the revised Plan and the action level for nitrate was set to be $25 \%$ of the MCL (i.e., $2.5 \mathrm{ppm}$ ). Given the complex groundwater flow associated with the HTF, a relatively large number of locations were selected for current CA monitoring of nitrate at HTF. These locations were based on those included in the Site Tank Farm Monitoring Plan (Wells, 2005). The "A" wells are set in the Gordon Aquifer. The "B" and "D" wells are set in the lower and upper zones of the Upper Three Runs Aquifer, respectively. The letter " $R$ " in a well name indicates the well replaces an older well.

In FY2009, two of the designated HTF CA monitoring wells (HAA 4D and HAA 11D) exceeded the action level for nitrate (2.5 ppm action level vs. $8.15 \mathrm{ppm}$ for HAA 4D and $3.79 \mathrm{ppm}$ for HAA 11D) but were below the drinking water standard for nitrate $(10 \mathrm{ppm})$. Both of the monitoring wells are " $\mathrm{D}$ " wells and located in the upper zones of the Upper Three Runs Aquifer. Neither of these wells was sampled in FY2010 because both wells were dry when attempting to sample them. None of the other nitrate monitoring locations (Table 16) exceeded the action level in FY2010.

Monitoring for nitrate is not expected to be proposed in the upcoming revision of the monitoring plan. This is because HTF is no longer a major contributing source in the new CA. Since the results for nitrate do not exceed the MCL they are not considered significant. Nonetheless, an action was taken under CA Maintenance to determine if elevated nitrate concentrations were above background nitrate or could be correlated with radionuclide migration.

\subsection{Investigation of HTF Groundwater Nitrate Concentrations}

In 2010 a number of actions have been taken to better understand the 2009 results for nitrate at designated CA monitoring wells at the HTF. Actions taken in 2010 include reviewing the historical nitrate data in order to better establish a range for background nitrate concentration for HTF. Another action was to review historical data for HTF monitoring locations including nitrate data as well as a number of other analytes including gross alpha, nonvolatile beta, uranium, neptunium, Tc-99, I-129 and $\mathrm{pH}$. The nitrate concentration data were compared with other analytes at the same locations to determine whether the elevated nitrate could be correlated with any radionuclides or any other gross indicators for radionuclide migration. The details of these actions are described below.

Since background data for nitrate is not available prior to the establishment of the HTF both data for HTF and other SRS sites were considered in order to establish a background nitrate concentration for HTF. Nitrate concentration can be impacted by a number of factors including contaminant migration as well as natural and anthropogenic activities. Prior to the 1950s, the area that now makes up the SRS was almost entirely an agricultural site. Figure 17 shows a historical aerial photo depicting the extent of farming throughout the site along with the locations of a number of wells considered to be "background" or locations expected to be less impacted by SRS activities. Table 17 shows the nitrate monitoring data for SRS background locations. The average background nitrate concentration for all locations was calculated to be $1.12 \mathrm{ppm}$ with a standard deviation of 1.06. For comparison, when the Performance Assessment Monitoring Plan for the Z-Area SDF was implemented (Cook et al, 2000), nitrate monitoring data for well ZBG-1 was used to calculate a conservative upper tolerance limit of $1.41 \mathrm{ppm}$ as background.

Table 18 shows all of the historical nitrate monitoring data available for the two groundwater monitoring locations that exceeded the action level in FY2009 (HAA 4D or HAA 11D). Nitrate concentrations for HAA 4D are definitely trending higher over the last 15 years. Figure 18 shows the 1993 water table wells in HTF including the locations for HAA 4D or HAA 11D. Considering nitrate data for other HTF wells, the deeper HAA A and B screen wells were near or below the background average of $1.12 \mathrm{ppm}$. The D screen wells were on average higher than the A and B screen wells, although these nitrate concentrations (Table 19) are also comparable to site SRS background nitrate values with the notable exceptions of the two wells exceeding the action level (HAA 4D and HAA 11D). 
SRNS-STI-2011-00024, Revision 0

Table 16. FY 2010 Nitrate-Nitrite CA Monitoring Data

\begin{tabular}{|c|c|c|c|c|c|c|}
\hline $\begin{array}{l}\text { Monitoring } \\
\text { Location }\end{array}$ & Type & $\begin{array}{l}\text { Sampling } \\
\text { Location }\end{array}$ & Sampling Date & $\begin{array}{l}\text { Result } \\
\text { (ppm) }\end{array}$ & $\begin{array}{l}\text { Action Level } \\
\quad(\text { ppm) }\end{array}$ & $\begin{array}{c}\text { Exceeds } \\
\text { action } \\
\text { level }\end{array}$ \\
\hline \multirow{33}{*}{ H Tank Farm } & well & HAA4A & $8 / 25 / 2010$ & $0.19^{* *}$ & 2.5 & no \\
\hline & well & HAA4B & $8 / 25 / 2010$ & 0.62 & 2.5 & no \\
\hline & well & HAA4D & Not Sampled & -- & 2.5 & -- \\
\hline & well & HAA7A & $8 / 25 / 2010$ & 0.29 & 2.5 & no \\
\hline & well & HAA7B & $8 / 25 / 2010$ & $0.127 * *$ & 2.5 & no \\
\hline & well & HAA7B & $8 / 25 / 2010$ & $0.127 * *$ & 2.5 & no \\
\hline & well & HAA7D & $8 / 25 / 2010$ & 1.17 & 2.5 & no \\
\hline & well & HAA8A & $8 / 25 / 2010$ & 0.35 & 2.5 & no \\
\hline & well & HAA8B & $8 / 25 / 2010$ & $0.199 * *$ & 2.5 & no \\
\hline & well & HAA8D & $8 / 25 / 2010$ & 1.28 & 2.5 & no \\
\hline & well & HAA 9AR & $8 / 23 / 2010$ & $0.0975^{* *}$ & 2.5 & no \\
\hline & well & HAA 9B & $8 / 23 / 2010$ & 0.308 & 2.5 & no \\
\hline & well & HAA 9D & $8 / 23 / 2010$ & 1.59 & 2.5 & no \\
\hline & well & HAA $10 \mathrm{AR}$ & $8 / 23 / 2010$ & 0.305 & 2.5 & no \\
\hline & well & HAA 10B & $8 / 23 / 2010$ & 0.86 & 2.5 & no \\
\hline & well & HAA 10D & $8 / 23 / 2010$ & 0.322 & 2.5 & no \\
\hline & well & HAA 11A & $8 / 24 / 2010$ & $0.23 * *$ & 2.5 & no \\
\hline & well & HAA 11B & $8 / 24 / 2010$ & 0.76 & 2.5 & no \\
\hline & well & HAA 11D & Not Sampled & -- & 2.5 & -- \\
\hline & well & HAA $12 \mathrm{~A}$ & $8 / 24 / 2010$ & 0.352 & 2.5 & no \\
\hline & well & HAA 12B & $8 / 24 / 2010$ & 0.5 & 2.5 & no \\
\hline & well & HAA 12D & Not Sampled & -- & 2.5 & -- \\
\hline & well & HAA 13A & Not sampled & -- & 2.5 & -- \\
\hline & well & HAA 13B & $8 / 24 / 2010$ & 0.805 & 2.5 & no \\
\hline & well & HAA 13B & $8 / 24 / 2010$ & 0.79 & 2.5 & no \\
\hline & well & HAA 13D & Not Sampled & -- & 2.5 & no \\
\hline & well & HAA $14 \mathrm{~A}$ & $8 / 31 / 2010$ & $0.185^{*}$ & 2.5 & no \\
\hline & well & HAA 14B & $8 / 31 / 2010$ & $0.249 * *$ & 2.5 & no \\
\hline & well & HAA 14D & Not Sampled & -- & 2.5 & -- \\
\hline & well & HAA $15 \mathrm{~A}$ & Not Sampled & -- & 2.5 & -- \\
\hline & well & HAA 15B & $8 / 31 / 2010$ & 1.13 & 2.5 & no \\
\hline & well & HAA 15B & $8 / 31 / 2010$ & 1.11 & 2.5 & no \\
\hline & well & HAA 15D & Not Sampled & -- & 2.5 & -- \\
\hline
\end{tabular}

Analysis method: Nitrogen, Nitrate/Nitrite, EPA353.2. Laboratory counting values are provided on the table, values with * are below the laboratory's quantitation limits (U qualifier); values with ** are below the laboratory's quantitation limits but were able to be estimated (J qualifier). 
SRNS-STI-2011-00024, Revision 0

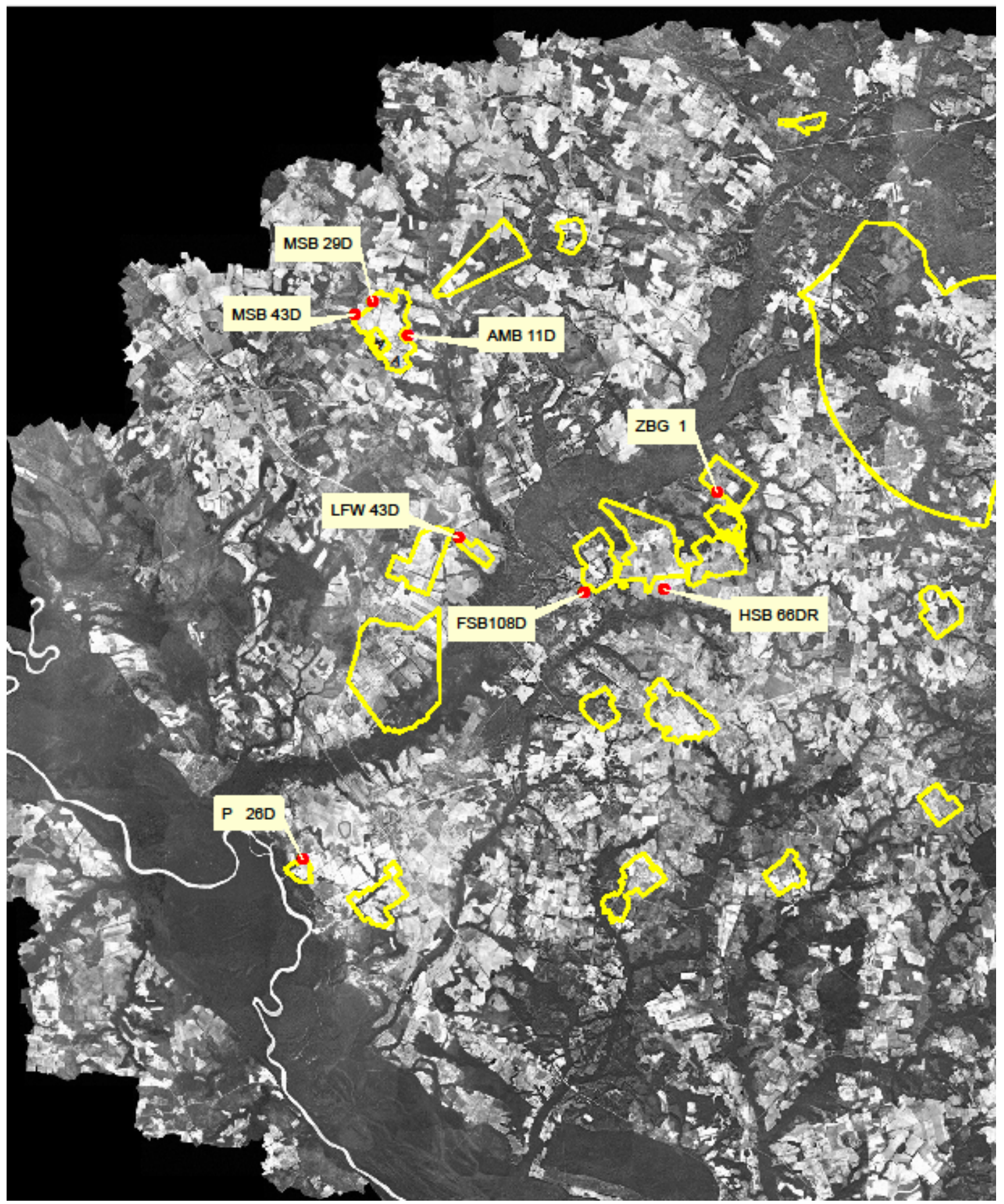

Figure 17. Background nitrate locations are shown overlaid on a historical aerial photograph depicting the extent of farming (lighter areas) prior to establishment of the SRS 
Table 17. Average nitrate monitoring data for each background monitoring location (January 2005 through May 2010).

\begin{tabular}{|c|c|c|}
\hline Sampling Location & $\begin{array}{c}\text { Avg } \\
\text { (ppm) }\end{array}$ & $\begin{array}{c}\text { Std Dev } \\
\text { (ppm) }\end{array}$ \\
\hline AMB 11D & 0.68 & 0.16 \\
\hline FSB108D & 1.17 & 0.61 \\
\hline HSB 66DR & 2.31 & 0.60 \\
\hline LFW 43D & 0.34 & 0.22 \\
\hline MSB 43D & 1.35 & 0.34 \\
\hline P 26D & 0.46 & 0.19 \\
\hline ZBG 1 & 1.56 & 0.42 \\
\hline Avg (all locations) & 1.12 & 1.06 \\
\hline
\end{tabular}

These two wells are above typical site background levels for nitrate and below MCL's used as a basis for selection of action levels. However, when other historical monitoring data for these locations and other locations in $\mathrm{H}$ Area are considered, there does not appear to be any radionuclide data or other data that can be correlated directly with nitrate levels. However, HAA 4D has consistently yielded nonvolatile beta detections above the practical quantitation limit (PQL) with the average since 2003 being $31 \mathrm{pCi} / \mathrm{L}$ although 11D has been consistently below detection. The average gross alpha value for HAA 4D since $2003(19 \mathrm{pCi} / \mathrm{L})$ is slightly above the MCL of $15 \mathrm{pCi} / \mathrm{L}$ although HAA $11 \mathrm{D}$ results for the same time period were below detection with the exception of one result which was below the PQL. Other HAA monitoring locations with detectible nonvolatile beta do not have elevated nitrate levels. Tritium results for both locations have been near or below the MCL of $20 \mathrm{pCi} / \mathrm{mL}$ with the average measured since 2003 for HAA $4 \mathrm{D}(11 \mathrm{pCi} / \mathrm{mL})$ being lower than the average measured since 2003 for HAA $11 \mathrm{D}(17 \mathrm{pCi} / \mathrm{mL})$. (It should be noted that rainfall in this area is known to have elevated tritium concentrations [see section 3.2.1.3].) Gross alpha and nonvolatile beta monitoring of H Tank Farm wells was eliminated in a past revision of the CA monitoring plan due to difficulties in applying these gross results to the specific radionuclides of concern. Other relevant radionuclides such as uranium isotopes, neptunium-237, strontium-90 and technetium-99 have not been measured since the 1990s and were below quantification limits at that time.

\subsection{Conclusions of HTF Groundwater Nitrate Investigation}

Based on the results of the $1997 \mathrm{CA}$, the HTF was determined to be a major contributor to flux to the SRS creeks and therefore CA monitoring has been carried out in groundwater in close proximity to the HTF. However, because of the complexity of the groundwater flow around the HTF a relatively large number of monitoring wells was included in the CA Monitoring Plan Revision (Crapse, 2009). In fact the existence of a groundwater divide does not allow for the monitoring locations to be placed such that the cumulative impact of the HTF on the groundwater can be evaluated as such.

The investigation into these nitrate-sampling locations showed that HAA 4D and 11D were elevated above background, but below drinking water standards. A review of historical data showed nitrate could not be correlated directly with any radionuclide data.

In the new revised 2009 CA (which considered different Points of Assessment for the evaluation) the HTF is no longer considered a major contributing source. Therefore, CA monitoring at such close proximity to HTF will not likely be warranted in future revisions of the CA Monitoring Plan. However, continued monitoring of these locations at the HTF Facility will continue as appropriate through SRS site programs such as the Tank Farm Monitoring Program as these facilities continue to operate and are decommissioned. 
SRNS-STI-2011-00024, Revision 0

Table 18. All available historical nitrate monitoring data for HAA4D and HAA11D.

\begin{tabular}{|c|c|c|c|c|c|c|c|}
\hline $\begin{array}{l}\text { Monitoring } \\
\text { Location }\end{array}$ & Type & $\begin{array}{l}\text { Sampling } \\
\text { Location }\end{array}$ & $\begin{array}{c}\text { Sampling } \\
\text { Date }\end{array}$ & $\begin{array}{l}\text { Result } \\
\text { (ppm) }\end{array}$ & Method & $\begin{array}{c}\text { Action } \\
\text { Level } \\
\text { (ppm) }\end{array}$ & $\begin{array}{c}\text { Exceeds } \\
\text { action } \\
\text { level } \\
\end{array}$ \\
\hline \multirow{15}{*}{ H Tank Farm } & well & HAA4D & $6 / 16 / 1994$ & $0.052 *$ & EPA300.0 & 2.5 & no \\
\hline & well & HAA4D & 7/20/1994 & 1.25 & EPA300.0 & 2.5 & no \\
\hline & well & HAA4D & $12 / 8 / 1994$ & 4.62 & EPA353.2 & 2.5 & yes \\
\hline & well & HAA4D & $12 / 8 / 1994$ & 4.95 & EPA353.2 & 2.5 & yes \\
\hline & well & HAA4D & $2 / 27 / 1995$ & 4.9 & EPA300.0 & 2.5 & yes \\
\hline & well & HAA4D & $7 / 31 / 1995$ & 5.15 & EPA353.1 & 2.5 & yes \\
\hline & well & HAA4D & $12 / 22 / 1995$ & 5.18 & EPA353.1 & 2.5 & yes \\
\hline & well & HAA4D & $12 / 22 / 1995$ & 5.04 & $\mathrm{EPA}_{353.1^{a}}$ & 2.5 & yes \\
\hline & well & HAA4D & $3 / 6 / 1997$ & 4.52 & $\mathrm{EPA}^{253.1^{a}}$ & 2.5 & yes \\
\hline & well & HAA4D & $3 / 11 / 1998$ & 7.5 & $\mathrm{EPA}^{253.1^{a}}$ & 2.5 & yes \\
\hline & well & HAA4D & $10 / 5 / 2005$ & 7.75 & $\mathrm{EPA} 33.1^{a}$ & 2.5 & yes \\
\hline & well & HAA4D & $9 / 17 / 2008$ & 7.22 & EPA353.2 ${ }^{a}$ & 2.5 & yes \\
\hline & well & HAA4D & $9 / 1 / 2009$ & 8.15 & EPA353. $2^{a}$ & 2.5 & yes \\
\hline & well & HAA 11D & $7 / 27 / 2006$ & 3.79 & EPA353.1 ${ }^{a}$ & 2.5 & yes \\
\hline & well & HAA 11D & $8 / 26 / 2009$ & 3.03 & EPA353.2 & 2.5 & yes \\
\hline
\end{tabular}

${ }^{a}$ denotes analyte name Nitrate-Nitrite as Nitrogen all others are analyte name Nitrate, values with * are below the laboratory's quantitation limits (U qualifier).

Table 19. Average nitrate concentrations for HAA monitoring wells.

\begin{tabular}{|c|c|c|c|c|c|}
\hline $\begin{array}{l}\text { Monitoring } \\
\text { Location }\end{array}$ & Type & $\begin{array}{l}\text { Sampling } \\
\text { Location }\end{array}$ & $\begin{array}{c}\text { Average } \\
\text { Result } \\
\text { (ppm) }\end{array}$ & $\begin{array}{c}\text { Action } \\
\text { Level } \\
\text { (ppm) }\end{array}$ & $\begin{array}{c}\text { Exceeds } \\
\text { action } \\
\text { level }\end{array}$ \\
\hline \multirow{16}{*}{ H Tank Farm } & well & HAA1D & 0.92 & 2.5 & no \\
\hline & well & HAA2D & 0.39 & 2.5 & no \\
\hline & well & HAA3D & 0.77 & 2.5 & no \\
\hline & well & HAA4D & 5.10 & 2.5 & yes \\
\hline & well & HAA6D & 0.69 & 2.5 & no \\
\hline & well & HAA7D & 1.73 & 2.5 & no \\
\hline & well & HAA8D & 1.36 & 2.5 & no \\
\hline & well & HAA9D & 1.4 & 2.5 & no \\
\hline & well & HAA10D & 0.41 & 2.5 & no \\
\hline & well & HAA11D & 3.41 & 2.5 & yes \\
\hline & well & HAA12D & 1.57 & 2.5 & no \\
\hline & well & HAA13D & 1.9 & 2.5 & no \\
\hline & well & HAA14D & 2.16 & 2.5 & no \\
\hline & well & HAA16D & 0.71 & 2.5 & no \\
\hline & well & $\begin{array}{c}\text { All HAA B } \\
\text { wells }\end{array}$ & 0.38 & 2.5 & no \\
\hline & well & $\begin{array}{l}\text { All HAA A } \\
\text { wells }\end{array}$ & 0.16 & 2.5 & no \\
\hline
\end{tabular}




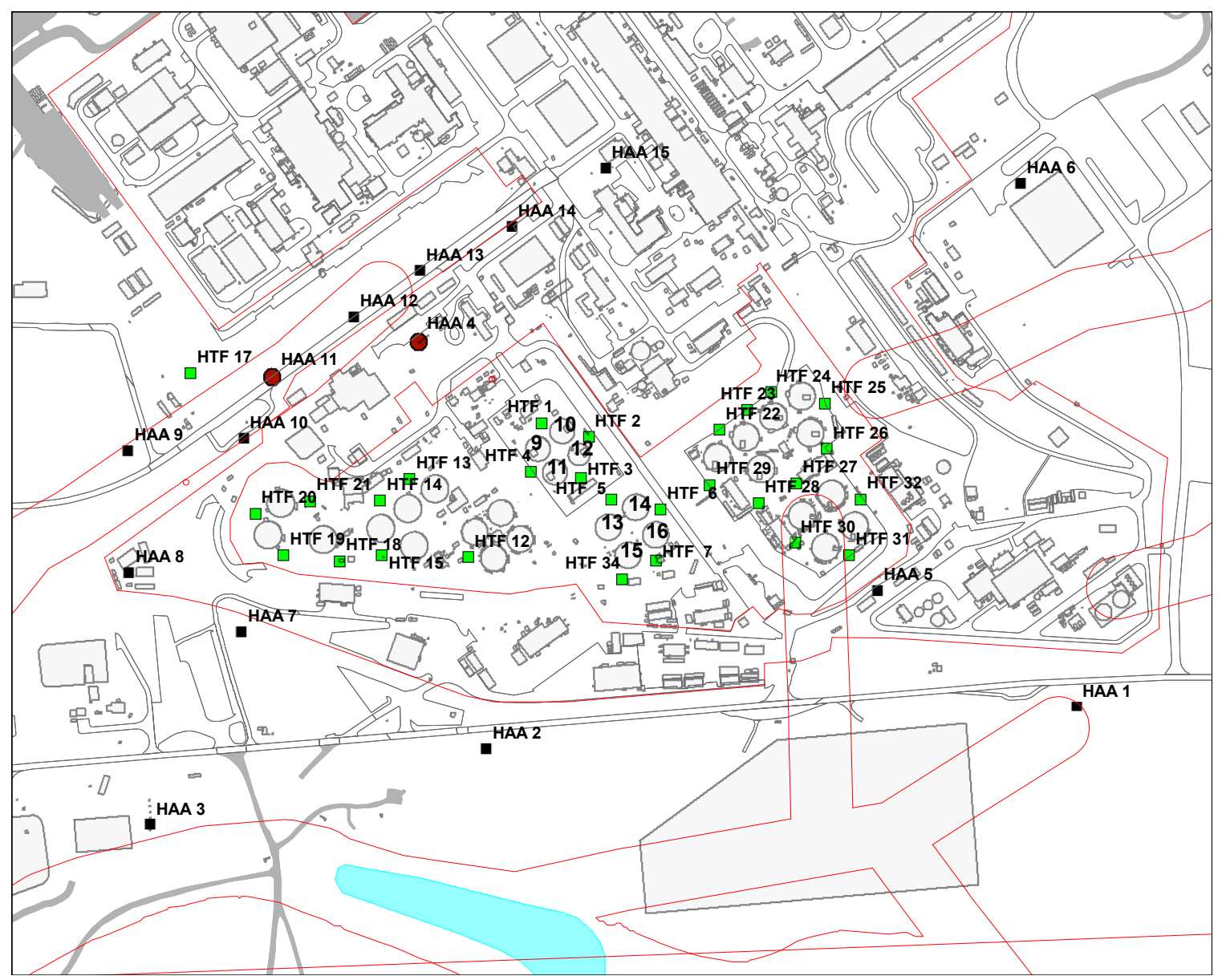

Figure 18. Showing HAA and HTF well locations and HTF tank locations (Tanks 9-12 are Type 1 tanks; Tanks 13-16 are Type 2 tanks)

\subsubsection{Stream Monitoring}

Tritium continues to be monitored as the only radionuclide expected to occur in SRS streams in the near term. In FY2010 average annual tritium levels at all four stream monitoring locations (U3R-1A, U3R-4, FMA7, and FM6 (Table 15) remained below the action levels. Previously in 2005, annual average tritium results at Fourmile Branch monitoring location FMA7 was above the action level. This previous measurement was determined to be the result of short term site operations associated with remediation activities rather than indicative of a trend requiring further action at this time. The long term trend is that tritium concentrations in Four Mile Branch are decreasing. 


\subsection{RESEARCH AND DEVELOPMENT}

\subsubsection{Past Events}

Annual Reviews of the Performance Assessments are conducted for the ELLWF (documented herein) and the SDF (SRR, 2010a) as well as for the Composite Analysis (documented herein). Results of R\&D activities are summarized from the respective Annual Reviews.

\subsubsection{Impact of SA/PA Revisions on the CA}

No Z-Area SAs were conducted in FY2010. No CA SAs were conducted in FY2010 due to the ongoing CA approval process.

The one SA listed below is for the ELLWF, and the results of the SA did not impact the E Area PA. Consequently, there were no impacts to the CA for this SA.

1. SA of Tritium Disposal Limits for E-Area Slit Trench 4 (Collard et al, 2010)

The revised SDF PA (SRR, 2009) is currently in review. The revised SDF PA has received DOE LowLevel Waste Federal Review Group (LFRG) approval for review by the Nuclear Regulatory Commission (NRC). The review has been initiated by the NRC under their monitoring role per the Ronald Reagan National Defense Authorization Act of Fiscal Year 2005 (NDAA Section 3116). The SDF PA Annual Review showed that operations conducted through FY2010 were within the performance envelope analyzed in the 1992 PA and 2005 SA.

The PA for the FTF at the SRS (SRR, 2010b) provides information to support subsequent DOE, NRC, SCDHEC and EPA Tank Closure Program actions and decisions, including a waste determination (WD) and closure plans. In FY10 DOE submitted the Draft FTF 3116 Basis Document to the NRC for consultation under NDAA Section 3116.

\subsubsection{Impacts of UDQEs on the CA}

UDQEs determine whether or not a proposed action or new information (discovery) is within the bounds of the analysis performed in the PA. In a few cases, the analysis may result in the proposed action being prohibited or, for a discovery, require a corrective action. Those discoveries or proposed actions not bounded by the PA yet needing implementation require a SA to change the PA baseline. The SA determines if limits can be increased and still meet DOE performance objectives.

No Saltstone UDQEs were completed in FY2010.

The following E-Area UDQE was prepared and approved by the PARC in FY2010:

- Unreviewed Disposal Question Evaluation: Installation of Additional Concrete Anchors in the Floor of LAW Vault Cell 11 to Support an Extension of the Temporary Airlock Enclosure (Jones and Phifer, 2010)

In this case, the conclusions of the UDQE do not alter the results or conclusions of the 2008 PA. Therefore, there is no impact to the CA.

\subsubsection{Impacts of Preliminary Studies on the CA}

PA Preliminary Studies. The following list PA Preliminary Studies were conducted in FY2010. The first sixteen studies listed are for the ELLWF (see Section 3.3.1.3). The last six studies listed are for the SDF. Preliminary studies produce supporting data to the E-Area and/or Z-Area PA baseline. Data from these 
studies are not incorporated into the baseline of the facility without first producing a SA. Therefore, there is no impact from these studies on the results of the CA.

1. Re-assessment of the Condition of the Bamboo Nursery (Nelson, 2009)

2. Neptunium IV and V Sorption to SRS Sediments (Kaplan, 2009a)

3. Conditions Impacting Corrosion of Discarded ETP Carbon Vessels, (Reboul and Brigmon, 2009)

4. ETP Carbon Vessel Post Burial Assessment (Estochen, 2010a)

5. Radionuclide Inventory Associated with HWCTR Components (Vinson et al, 2010)

6. Radionuclide Characterization of the HWCTR Steam Generators (Reboul and Vinson, 2010)

7. HWCTR Burial Failure Analysis (Estochen, 2010b)

8. Rapid Response Evaluation of Onsite Disposal Options for HWCTR

9. Geochemical Data Package for Performance Assessment Calculations Related to the Savannah River Site (Kaplan, 2009b)

10. Closure Cap Drainage Layer Hydraulic Conductivity Over Time: Literature Search (Jones, 2010)

11. Iodine Geochemistry in the SRS Subsurface and Wetland Sediments (Kaplan et al, 2010)

12. Characterization Plan for VL-26 Lysimeter Field Characterization at Slit Trench 1 (Millings and Bagwell, 2010)

13. Summary Report for the VL-26 Lysimeter Field Characterization at Slit Trench 1 (Millings et al, 2010)

14. Lysimeter Demolitions and Modification at Slit Trenches (Bagwell, 2010)

15. E-Area Concrete and Grout Durability Simulations by SIMCO Technologies (Langton, 2009)

16. Proof-of-Concept Modeling of Cracked Porous Medium (Dong et al, 2010)

17. Saltstone Characterization and Parameters for Performance Assessment Modeling (Langton, 2010).

18. Hydraulic and Physical Properties of ARP/MCU Saltstone Grout (Dixon et al, 2010)

19. Iodine, Neptunium, Plutonium and Technetium Sorption to Saltstone Under Oxidizing and Reducing Conditions (Lilley et al, 2009)

20. Air and Radon Pathway Modeling for the Saltstone Disposal Facility(Dixon et al, 2008)

21. Evaluation of Flexible Wall Permeameter in 773-A B110 for Use on Saltstone Samples (Nichols et al, 2009)

22. Characterization of Core Sample Collected from the Saltstone Disposal Facility (Cozzi and Duncan, 2009)

CA Preliminary Studies. One CA Preliminary Study was completed during FY2010: 
Iodine Geochemistry in the SRS Subsurface and Wetland Sediments. Sorption studies conducted during this first year of the study established conclusively that iodate $\left(\mathrm{IO}_{3}{ }^{-}\right.$aq $)$sorbed appreciably more strongly to SRS sediments than iodide ( $\mathrm{I}^{-}$aq $)$. Groundwater samples were collected from an I-129 contaminant plume in F-Area and it was determined that not only iodide, but also the more strongly sorbing iodate was present. The current recommended values for iodine sorption used in SRS PAs and CA are conservatively based on previous iodine sorption measurements conducted with iodide. New values based on radioidine speciation will be recommended once this work is completed. (Kaplan et al, 2010)

\subsubsection{CA Maintenance}

All CA Maintenance activities in FY2010 were directed to review and approval of the new CA.

\subsubsection{Future Events}

\subsubsection{SAs}

No CA Special Analyses are planned.

\subsubsection{UDQEs \\ No CA UDQ Evaluations are planned.}

The SRS CA is a management tool intended to provide a reasonable expectation that future corrective or remedial actions will not be required in association with SRS PA facilities to ensure protection of the public and the environment. The new CA (SRNS, 2010c) includes public dose projection accounting for all end state SRS radiological sources that can interact with SRS PA facilities (i.e., all SRS CERCLA, RCRA, D\&D, operating, and future facilities with projected end state radionuclide inventories). In FY11 SRS will be developing and implementing a CA "UDQE-like" process (Unreviewed Composite Analysis Question) in order to protect key CA inputs and assumptions about land use, end states, inventory and future work by evaluating changes for their impact on CA conclusions.

\subsubsection{Preliminary Studies}

Preliminary studies that support the ELLWF and SDF PA have significant commonality with those activities that support the CA. Therefore, those PA activities are also applicable in validation of the CA.

These preliminary studies will both improve the understanding of the migration of the major CA dose contributors, as well as reduce the uncertainty by developing more realistic modeling scenarios. Studies will focus on how the CA results were obtained, where the uncertainty lies, and how this uncertainty can be reduced. Most of the studies listed below focus on development of more realistic release scenarios and reduction of uncertainty.

Investigate Phenomenon of I-129 Concentrating at the Seepline. I-129 has been shown to be naturally attenuated in SRS sediments by processes that are not accounted for in the present CA. These attenuating processes occur in organic rich environments, such as seeplines/wetlands. In FY2010 SRNL quantified sorption of radioiodine $\left(\mathrm{I}^{-}\right.$and $\left.\mathrm{IO}_{3}^{-}\right)$to wetland sediments and compared to subsurface sediments. It would be beneficial to develop a better understanding of the specific mechanisms involved between iodine and iodate and the sediments, especially the wetland soils. This understanding would be used to technically support and improve PA and CA models. In FY11, laboratory column experiments will be conducted with iodide, iodate, and organo-iodine, all species that naturally occur in SRS groundwater, to study flow characteristics and to measure, amongst other parameters, Kd values.

Develop an SRS Regional Groundwater Model. One of the secondary issues raised by the LFRG Review Team in their review of the new SRS CA (SRNS, 2010c) was the need for a comprehensive, sitewide groundwater model to replace the patchwork of models used in the analysis. In FY11, SRNL will begin 
developing an SRS regional groundwater model, encompassing the entire SRS, from which boundary controls for smaller SRS groundwater_models with greater grid resolution can be extracted and the impacts of transient_drought and wet conditions on contaminant transport can be evaluated. This effort at a minimum should include: identification of model boundaries and boundary_conditions; synthesis of existing hydrogeologic data; database development; identification of data gaps; collection of field data; archiving field samples and data_as appropriate; development of appropriate recharge (infiltration) / drain top surface boundaries based upon surface conditions; development of low, average, and high potentiometric surfaces for the water table and underlying aquifers; model development; and development of advanced visualization tools.

\subsubsection{CA Maintenance}

Establish Formal CA Maintenance Program. Maintenance of the original 1997 SRS CA consisted of performing annual CA reviews and evaluating PA's, SA's and UDQE's for impacts on CA conclusions. The recently approved SRS CA (SRNS, 2010c) is being recognized by DOE and site management for its potential usefulness in linking risk assessments to future land use plans making CA maintenance a sitelevel priority. The starting point of the maintenance program is to establish a baseline followed by development of methods, protocols and tools for keeping that baseline current. An archival system has been developed, along with a CA data management plan, for providing configuration control on all models, inputs, outputs and supporting data used in development of the CA baseline and future baseline revisions. The CA archive system is located on the SRNL High Performance Computer File Server. In FY2011, procedures and inter-organizational agreements will be established among the various data owners defining roles and responsibilities for maintaining/updating datasets (e.g., radionuclide inventory report and datasets) and key inputs and assumptions of the analysis. The current UDQ process, developed primarily with PA's in mind, will be revised for application to CA maintenance. A CA Review Committee will be chartered to oversee the review and approval of proposed changes and impact of new information on the CA.

Develop New CA Monitoring Plan. The current CA monitoring plan is aligned with the 1997 CA and has been constructed around the existing site environmental monitoring program to minimize the cost of implementation. An item has been added to the PA/CA Maintenance Plan to review the CA monitoring program in FY2011 to develop a more comprehensive CA monitoring plan to verify the new CA predictions and to reevaluate current monitoring locations, radionuclides monitored, and sampling frequencies in light of the results of the new CA.

Validation of CA with SMP Monitoring Results. This task involves comparison of SMP well and stream data with CA results and will be conducted on an annual basis in accordance with the approved revision of the CA monitoring plan. The results will be documented as part of the PA/CA Annual Review. If data evaluation identifies the need for additional monitoring, SRNL will revise the CA Monitoring Plan and other related documents. Next year's monitoring program will be aligned with the new CA monitoring plan.

Initial CA Improvements. The revised CA (SRNS, 2010c) was unanimously approved by the DOE-HQ LFRG on June 10, 2010. During development of this SRS CA revision, additional potential future work items were identified for consideration. In anticipation of LFRG review team comments, planning was started for the following three high priority CA improvements in parallel with the ongoing review. Work will commence on these activities in FY11. The remaining activities identified in the Future Work section of the new CA have been assigned to outyear maintenance.

1) Enhanced CA Uncertainty Analysis. As part of CA maintenance, SRNL committed to improving the uncertainty/sensitivity analysis. The analysis included in the CA was limited to considering at most five sources in a separate calculation for each POA. To perform the uncertainty calculations in a reasonable amount of time, the analysis was also limited to 400 realizations and the time steps used for the uncertainty analysis were increased from what was used in the CA base case analysis. The previous uncertainty analysis was constrained by GoldSim licensing which was limited to running at most four realizations simultaneously. Some of the limitations on the number of realizations that can be practically run and the 
simulation time steps have been removed by building a cluster of three HP Proliant servers with a total of 3664 bit processors and by licensing the GoldSim DP-Plus distributed processing software. This will allow us to run as many as 35 realizations simultaneously (one processor is reserved as a master process that controls running the realizations). These enhancements to our computing capabilities make uncertainty analysis using 1000 realizations with finer time steps and more sources feasible.

2) Update of CA End State Inventory Report. A re-evaluation of SRS facility and waste site lists will be conducted to identify any facilities or waste sites, which were overlooked in the 2009 CA inventory (i.e., SRS facilities and waste sites anticipated to have an "End State" radionuclide inventory that were not included in the 2009 CA inventory).

3) Lower Three Runs Stream Bed Inventories. As summarized in Section 10.0 of the new CA, Cs-137 in the Lower Three Runs Integrator Operable Unit (i.e., streambed and floodplain) is the primary CA dose driver. Therefore the uncertainty associated with the LTR IOU inventory (i.e., inventory distribution) will be developed along with a re-evaluation of the base case inventory. While Cs-137 is the most significant and abundant radionuclide associated with the LTR IOU, it is not the only radionuclide. Therefore streambed inventories and distributions for other radionuclides will also be developed. This effort will initially focus on existing sampling and analysis data. However this effort may require additional streambed and floodplain sampling and analysis that may include horizontal and vertical distributions of the radionuclides and correlation with water concentrations including Cs-137. 
SRNS-STI-2011-00024, Revision 0

\subsection{REFERENCES}

(Aleman and Flach, 2010) S. E. Aleman and G. P. Flach, Acceptance Testing for PORFLOW Version 6.30.1, SRNL-L6200-2010-00016.

(Arnett and Mamatey, 2001) M. W. Arnett and A. R. Mamatey, Savannah River Site Environmental Monitoring Report for 2001, WSRC-TR-2001-00474.

(Bagwell, 2010) L. A. Bagwell, Documenting Lysimeter Demolitions and Modifications as Slit Trench 5, SRNL Memorandum, SRNL-L6000-2010-00010, August 31, 2010.

(Collard and Hamm, 2008) L. B. Collard and L. L. Hamm, Special Analysis of Operational Stormwater Runoff Covers Over Slit Trenches, SRNL-STI-2008-00397, Revision 0, December 18, 2008.

(Collard et al, 2010) L. B. Collard, L. L. Hamm and F. G. Smith, Special Analysis of Tritium Disposal Limits for E-Area Slit Trench 4, SRNL-STI-2010-00263, Revision 0, May 3, 2010.

(Cook, 2002) J. R. Cook, Performance Assessment Monitoring Plan for the E-Area Low-Level Waste Facility, SW\&I-SWE-98-0153, Rev. 4, December 2002.

(Cook et al, 2000) J. R. Cook, E. L. Wilhite and K. E. Young, Performance Assessment Monitoring Plan for the Z-Area Saltstone Disposal Facility, WSRC-RP-2000-00325, Rev. 0, June 21, 2000.

(Cozzi and Duncan, 2009) A. D. Cozzi and A. J. Duncan, Characterization of Core Sample Collected from the Saltstone Disposal Facility, SRNL-STI-2009-00804, Rev. 0, December 2009.

(Crapse, 2009) K. Crapse, Composite Analysis Monitoring Plan for the E-Area Low Level Waste Facility and the Z-Area Saltstone Disposal Facility, SRNL-RP-2009-00333, Rev. 0, April 2009.

(Dixon et al, 2010) K. Dixon, J. Harbour and M. Phifer, Hydraulic and Physical Properties of ARP/MCU Saltstone Grout, SRNL-STI-2009-00419, Rev. 0, May 2010.

(Dixon et al, 2008) K. Dixon., G. Flach, M. Denham and M. Phifer, Air and Radon Pathway Modeling for the Saltstone Disposal Facility, SRNL-STI-2008-00447, Rev. 0, December, 2008.

(DOE, 1999a) USDOE Order 435.1 Radioactive Waste Management Manual, U. S. Department of Energy, July 9, 1999.

(DOE, 1999b) Disposal Authorization Statement for the DOE Savannah River Site E-Area Vaults and Saltstone Disposal Facilities, U. S. Department of Energy, September 28, 1999.

(DOE, 2008a) Review Team Report for the E-Area Low-Level Waste Facility DOE-435.1 Performance Assessment at the Savannah River Site, February 4, 2008.

(DOE, 2008b) Disposal Authorization Statement for the Savannah River Site E-Area Low-Level Waste Facility, Revision 1, U. S. Department of Energy, July 2008.

(Dong et al, 2010) C. Dong, P. Song and S. Sun, Research Progress Report for the Project Entitled,

"The Proof-of-Concept Model for the Cementitious Barriers Partnership", Clemson University, Department of Mathematical Sciences, August 2010.

(EPA, 2008) Notice of Acceptability under the CERCLA Off-Site Rule, Memo J. I. Palmer to J. Allison, January 17, 2008. 
(Estochen, 2010a) E. G. Estochen, ETF Carbon Vessel Post Burial Failure Assessment, N-CLC-E00046, Revision 1, March 2010.

(Estochen, 2010b) E. G. Estochen, Heavy Water Component Test Reactor (HWCTR) Burial Failure Analysis, M-CLC-E-00048, July 29, 2010.)

(Fitzgerald, 2010) M. Fitzgerald, Geochemical Parameter Distributions for Modeled Materials at SRS, Revision 2, Neptune and Company, Inc. October 6, 2010.

(Holmes-Burns, 1999) H. Holmes-Burns, E-Area Monitoring Program - Phase 1A Vadose Zone Monitoring System for Disposal Trenches, SWD-SWE-99-0129, Revision 0, September 30, 1999.

(Jones, 2010) W. E. Jones, Closure Cap Drainage Layer Hydraulic Conductivity over Time: Literature Search, SRNL-L6000-2009-00020, Revision 0, April, 2010.

(Jones and Phifer, 2010) W. E. Jones and M. A. Phifer, Unreviewed Disposal Question Evaluation: Installation of Additional Concrete Anchors in the Floor of LAW Vault Cell 11 to Support an Extension of the Temporary Airlock Enclosure, SRNL-STI-2010-00196, Revision 0, August 12, 2010.

(Kaplan, 2009a) T. J. Miller, B. A. Powell and D. I. Kaplan, Neptunium IV and V Sorption to EndMember.Subsurface Sediments of the Savannah River Site, SRNL-STI-2009-00634, Rev. 0, November $13,2009$.

(Kaplan, 2009b) D. I. Kaplan, Geochemical Data Package for Performance Assessment Calculations Related to the Savannah River Site, SRNL-STI-2009-00473, Revision 0, March 15, 2010.

(Kaplan et al, 2010) D. I. Kaplan, K. Roberts and Seaman, Re: Iodine Geochemistry in SRS Subsurface and Wetland Sediments, SRNL-L3500-2010-00007, May 28,2010.

(Langton, 2008) C. A. Langton, Evaluation of Sulfate Attack on Saltstone Vault Concrete and Saltstone, Part II: Test Methods to Support Moisture and Ionic Transport Modeling Using the Stadium Code, SRNS-STI-2008-00052, Revision 0, September 13, 2008

(Langston, 2009) C. A. Langton, Final Report: E-Area LAWV/ILV Concrete and CIG Grout Durability Simulations for Exposure to Leachates with pHs Between 7 and 12.4, SRNL-STI-2009-00655, November 2009.

(Langton, 2010) C. A. Langton, Saltstone Characterization and Parameters for Performance Assessment Modeling, SRNL-STI-2010-00515, Rev. 0, September 30, 2010.

(Lilley et al, 2009) M. S. Lilley et al, Iodine, Neptunium, Plutonium and Technetium Sorption to Saltstone and Cement Formulations Under Oxidizing and Reducing Conditions, SRNL-STI-200900636, Rev. 0, December 16, 2009.

(Mamatey, 2003) A. R. Mamatey, Savannah River Site Environmental Monitoring Report for 2002, WSRC-TR-2003-00026, Revision 0.

(Mamatey, 2004) A. R. Mamatey, Savannah River Site Environmental Monitoring Report for 2003, WSRC-TR-2004-00015, Revision 0.

(Mamatey, 2005) A. R. Mamatey, Savannah River Site Environmental Monitoring Report for 2004, WSRC-TR-2005-00005, Revision 0.

(Mamatey, 2006) A. R. Mamatey, Savannah River Site Environmental Monitoring Report for 2005, WSRC-TR-2006-0007, Revision 0. 
(Mamatey, 2007) A. R. Mamatey, Savannah River Site Environmental Monitoring Report for 2006, WSRC-TR-2007-00008, Revision 0.

(Mamatey, 2008) A. R. Mamatey, Savannah River Site Environmental Monitoring Report for 2007, WSRC-STI-2008-00057, Revision 0.

(Mamatey, 2009) A. R. Mamatey, Savannah River Site Environmental Monitoring Report for 2008, SRNS-STI-2009-00190, Revision 0.

(Mamatey, 2010) A. R. Mamatey, Savannah River Site Environmental Monitoring Report for 2009, SRNS-STI-2010-00175, Revision 0.

(Millings, 2009a) M. R. Millings, Performance Assessment Monitoring Plan for the E-Area Low Level Waste Facility, SRNL-RP-2009-00534, Revision 0, April 2009.

(Millings, 2009b) M. R. Millings, Review of Lysimeter Cluster VL-26 at Slit Trench 1, SRNL Memorandum, SRNL-L6200-2009-00038, November, 2009.

(Millings and Bagwell, 2010) M. R. Millings and L. A. Bagwell, Characterization Plan for VL-26 Lysimeter Cluster, SRNL-STI-2010-00436, Revision 0, July 2010.

(Millings et al, 2010) M. Millings, L. Bagwell, J. Noonkester and K. Roberts, Summary Report for the VL-26 Lysimeter Field Characterization, SRNL-STI-2010-00436, Revision 0, July 2010.

(Nelson, 2009) E. A. Nelson, Re-assessment of the Condition of the Bamboo Nursery at SRS, SRNLTR-2009-00383, Rev. 0, October 2009.

(Nichols et al, 2009) R. Nichols et al, Evaluation of Flexible Wall Permeameter in 773-A B110 for Use on Saltstone Samples, SRNS-STI-2009-00768, November 2009.

(Phifer, 2010a) M. A. Phifer, Documenting Slit Trench Intact and Subsided Infiltration, SRNL Memorandum, SRNL-L6200-2010-00015, May 25, 2010.

(Phifer, 2010b) M. A. Phifer, Slit Trench Waste Representation, SRNL Memorandum, SRNL-L62002010-00018, June 15, 2010.

(Phifer et al, 2006) M. A. Phifer, M. R. Millings. G. P. Flach, Hydraulic Property Data Package for the E-Area and A-Area Soils, Cementitious Materials and Waste Zones, WSRC-STI-2006-00198, Rev. 0, September 2006.

(Phifer et al, 2009a) M. A. Phifer, K. P. Crapse, M. Millings, M. G. Serrato, Closure Plan for the EArea Low-Level Waste Facility, SRNL-RP-2009-00075, Revision 0, March 16, 2009.

(Reboul and Vinson, 2010) S. H. Reboul and D. E. Vinson, Radionuclide Inventory Associated with HWCTR Steam Generators, Q-CLC-A-00034, Revision 0, March 2010.

(Reboul and Brigmon, 2009) S. H. Reboul and R. L. Brigmon, Conditions Impacting Corrosion of Discarded ETP Carbon Vessels, SRNL-L3100-2009-00308, December 12, 2009.

(Roberts and Kaplan, 2009) K. A. Roberts and D. I. Kaplan, Reduction Capacity of Saltstone and Saltstone Components, SRNL-STI-2009-00637, Revision 0, November 30, 2009

(SRNS, 2010a) E-Area Low-Level Waste Facility and Savannah River Site Composite Analysis Maintenance Program FY2010 Implementation Plan, SRNS-RP-2010-00179, Revision 0 


\section{SRNS-STI-2011-00024, Revision 0}

(SRNS, 2010b) Annual Corrective Action Report for the F-Area Hazardous Waste Management Facility, the H-Area Hazardous Waste Management Facility and the Mixed Waste Management Facility (U), Volume II, SRNS-RP-2010-00172, Revision 0, April 2010.

(SRNS, 2010c) Savannah River Site DOE 435.1Composite Analysis, Volumes I and II, SRNL-STI2009-00512, Revision 0, June 10, 2010)

(SRR, 2009) Performance Assessment for the Saltstone Disposal Facility at the Savannah River Site, SRR-CWDA-2009-00017, October 2009.

(SRR, 2010a) FY2010 Annual Review Saltstone Disposal Facility (Z Area) Performance Assessment, SRR-CWDA-2010-00151, December 2010.

(SRR, 2010b) Performance Assessment for the F-Tank Farm at the Savannah River Site, SRS-REG2007-00002, Rev. 1, March 31, 2010.

(SRS, 2008) WSRC E7 Conduct of Engineering Manual, Revision 55, December 4, 2008.

(SRS, 2009) IS SRS Waste Acceptance Criteria Manual, Procedure 3.17 Low Level Radioactive Waste Acceptance Criteria, Revision 11, January 15, 2009.

(Swingle, 2010a) R. F. Swingle, SRNL-L3500-2010-00009, Rev. 0, June 10, 2010.

(Swingle, 2010b) R. F. Swingle to M. A. Phifer, Documentation of Acceptance of GoldSim, Version 9.60, Service Pack 4 for Use in Performance Assessment and Composite Analysis Activities, SRNLL3500-2010-00006, March 19, 2010.

(Swingle et al, 2010) R. Swingle, B. Butcher, K. Crapse, M. Millings, D. Sink, and G. Humphries, , FY2009 Annual Review E-Area Low-Level Waste Facility Performance Assessment and Composite Analysis, SRNS-RP-2009-01369, January 2010)

(SWM, 2009a) Documentation, Validation, and Protection of Inputs and Assumptions (U), SW-ENG0703, Revision 1, March 26, 2009

(SWM, 2009b) Procedure for Sampling SWMF Lysimeters (U), SW15.1-SOP-LYSI-01, Revision 23, December 21, 2009.

(SWM, 2009c) SRS Certification Program Review for Radioactive Waste Generators (U), SWWCAM-4, Revision 8, May 14, 2009

(SWM, 2009d) Performance Assessment (PA) Review Committee (U), SW-AP-1407, Revision 0, June 30, 2009

(SWM, 2010a) Procedure for Engineered Trench Sump Sampling and Pumping (U), SW15.1-SOPESUMP-01, Revision 11, September 23, 2010.

(SWM, 2010b) Procedure for E-Area Low Level Sump Sampling and Pumping (U), SW15.1-SOPLLS-01, Revision 8, January 26, 2010

(SWM, 2010c) Procedure for E-Area Vaults Subsidence and Low Activity Waste Vault Concrete Degradation Inspection (U), 724-EAV-50, Revision 5, February 11, 2010

(SWM, 2010d) Procedure for SWMF E-Area Inspections (U), SW15.6-INP-SWF-03, Revision 14, August 30, 2010. 
(SWM, 2010e) Procedure for SWMF Weekly E-Area Inspections (U), SW15.6-INP-SWF-02, Revision 7, May 20, 2010

(Tauxe and Catlett, 2010) J. Tauxe and K. Catlett, Notes on Revisions to the SRS ELLWF Trench Models, Neptune and Company, Inc. September 14, 2010.

(Vinson et al, 2010) D. E. Vinson, S. H. Reboul, L. L. Hamm and R. L. Webb, Radionuclide Inventory Associated with HWCTR Waste, Q-CLC-A-00033, Revision 1, October 2010.

(Wells, 2005) D. G. Wells, Monitoring Plan for the High Level Waste Tank Farms, WSRC-TR-200400631 , March 2005.

(Whiteside, 2010) T. S. Whiteside, Software Testing and Verification of PORFLOW 6.21.0, SRNLTR-2010-00023,

(WSRC, 1997) Composite Analysis for E-Area Vaults and Saltstone Disposal Facilities, WSRC-RP97-311, Revision 0, September 1997.

(WSRC, 1999) Addendum to the Composite Analysis for the E-Area Vaults and Saltstone Disposal Facilities, WSRC-RP-99-00844, September 23, 1999.

(WSRC, 2006) System Plan for Solid Waste Management, WSRC-RP-99-01092, Revision 9, December 2006.

(WSRC, 2008a) Performance Assessment and Composite Analysis Maintenance Program FY2008 Implementation Plan, WSRC-RP-2008-00534, Revision 0, May 2008.

(WSRC, 2008b) E-Area Low-Level Waste Facility DOE 435.1 Performance Assessment, WSRC-STI2007-00306, July 2008. 